\title{
How Natural Disasters Can Affect Environmental Concerns, Risk Aversion, and Even Politics: Evidence from Fukushima and Three European Countries ${ }^{+} *$
}

\author{
Jan Goebel $* *$ Christian Krekel $* * *$ Tim Tiefenbach $* * * *$ Nicolas R. Ziebarth
}

June 2015

\begin{abstract}
We study the impact of the Fukushima disaster on environmental concerns, well-being, risk aversion, and political preferences in Germany, Switzerland, and the UK. In these countries, overall life satisfaction did not significantly decrease, but the disaster significantly increased environmental concerns among Germans. One underlying mechanism likely operated through the perceived risk of a similar meltdown of domestic reactors. After Fukushima, more Germans considered themselves as "very risk averse". However, drastic German policy action shut down the oldest reactors, implemented the phaseout of the remaining ones, and proclaimed the transition to renewables. This shift in energy policy contributed to the subsequent decrease in environmental concerns, particularly among women, Green party supporters, and people living in close distance to the oldest reactors. In Germany, political support for the Greens increased significantly, whereas in Switzerland and the UK, this increase was limited to people living close to reactors.
\end{abstract}

Keywords: Fukushima, nuclear phaseout, environmental concerns, well-being, risk aversion, Green party

JEL codes: I18, I31, Q54

\footnotetext{
+ This is the pre-publication version of this paper, which is forthcoming the Journal of Population Economics. The final publication is available at Springer via http://dx.doi.org/10.1007/s00148-015-0558-8.

** DIW Berlin (German Institute for Economic Research), Mohrenstrasse 58, 10117 Berlin, Germany, E-Mail: igoebel@diw.de

*** DIW Berlin (German Institute for Economic Research), Graduate Center of Economic Research, Mohrenstrasse 58, 10117 Berlin, Germany, E-Mail: ckrekel@diw.de

**** German Institute for Japanese Studies Tokyo (DIJ), Jochi Kioizaka Bldg, 2F, 7-1 Kioicho, Chiyoda-ku, Tokyo 1020094, Japan, E-Mail: tiefenbach@dijtokyo.org

***** Corresponding author: Cornell University, Policy Analysis and Management (PAM), 106 Martha van Rensselaer Hall, Ithaca, NY 14853, DIW Berlin, and IZA Bonn, E-Mail: nrz2@cornell.edu, Phone: +1-(607) 255-1180, Fax: +1-(607) 255-4071
} 
"Fukushima taught us that we have to deal with risks differently."

Angela Merkel during the press conference announcing the nuclear phaseout on May 30, 2015.

"I conducted a re-assessment of [the remaining risks of] nuclear energy."

Angela Merkel in her State-of-the-Union Address on June 9, 2011

\section{Introduction}

On March 11, 2011, a worst-case scenario in the history of the civil use of nuclear energy occurred: a natural disaster triggered the Fukushima Daiichi nuclear accident. At about 3pm JST, the Tohoku earthquake, magnitude 9.0, struck off the east coast of Japan at an underwater depth of about 30km (19mi). It was the strongest earthquake to hit Japan since record-keeping began, triggering a gigantic tsunami with waves up to $40 \mathrm{~m}$ (133ft). The tsunami's dimensions by far exceeded the safety measures of the Fukushima Daiichi nuclear power plant, whose $5.7 \mathrm{~m}$ (19ft) sea walls were easily topped by up to $15 \mathrm{~m}$ (49ft) high waves hitting the plant. Although the safety measures met regulatory requirements, in total, three of the six reactors fully melted down, leading to a major release of radioactive material into the environment.

In the subsequent days, the dimensions of the catastrophe became apparent. Within 2 days, nearly 200,000 people were evacuated, an estimated 4.5 million were without electricity, and 1.5 million without water. In September 2011, the Japanese Policy Agency concluded that the entire disaster, inclusive of the earthquake, tsunami, and meltdown, resulted in 16,000 deaths, thousands of injured or missing people, and 400,000 collapsed or partially collapsed buildings (INPO, 2011). However, no short-term physical health damages from radiation were observed as of 2013 (WHO, 2013).

While physical damages were mainly limited to Japan and its surrounding sea areas, the disaster triggered political action in a country more than 5,000 miles distant: Germany. In response to the meltdown, the conservative government of Chancellor Angela Merkel made a sharp U-turn in its energy policy. In consensus with the liberal opposition, immediately after the disaster, the oldest reactors in Germany were temporarily shut down (Atommoratorium)-despite their reputation of being among the safest in the world and despite the marginal tsunami risk in Germany. On May 30, 2011, the government announced the $\mathrm{Nu}$ clear Phase-Out Bill (Atomausstieg) that would permanently shut down these oldest reactors. Moreover, the bill implemented the staggered phaseout of the remaining reactors and will lead to a complete shutdown of all nuclear power plants in Germany by 2022. It represents a direct and immediate response to the unexpected and exogenous Fukushima catastrophe. Figure 1 shows the timeline of the policy events following the disaster.

[Insert Figure 1 about here] 
This paper estimates the impact of the Fukushima catastrophe on environmental concerns, well-being, risk aversion, and political preferences in three European countries: Germany, Switzerland, and the UK. We exploit the timing of the disaster that is exogenous to the survey interview dates. In addition, we stratify the estimated effects by the geographic distances between respondents' residencies and the nearest nuclear power plant. Our findings show the following:

First, while we do not find much evidence that subjective well-being was significantly affected in Germany, Switzerland, or the UK, we do find that environmental concerns significantly increased among Germans. These findings demonstrate that disasters do not only have negative local effects but also impose negative externalities on distant countries, even if those countries are presumably not directly affected. For Germany, similar effects have been reported by Berger (2010) after the Chernobyl disaster and by Richter et al. (2013) after the Fukushima disaster. However, we enrich the existing literature by (i) netting out individual unobserved heterogeneity, (ii) stratifying the effects by the distances to nuclear power plants, and (iii) providing empirical evidence on the operating channels, with a particular focus on risk aversion. In addition, we analyze how political preferences changed in (iv) three European countries that differ in their energy policies and their policy responses. Finally, we ( $v$ ) provide a battery of robustness checks to verify the validity of the results.

Second, while the objective risk of a similar disaster did not change, subjective risk perceptions or individual risk tolerance may. Indeed, we find that the share of Germans who considered themselves as "very risk averse" increased significantly after Fukushima, in particular among people who lived in close proximity to reactors. This suggests that the perception of local risk factors may outweigh potential risk factors further away in other countries.

Third, after Fukushima, support for the Green party significantly increased in all three European countries, again most strongly among people who lived in close proximity to reactors. Phasing out of nuclear energy has been one of the core political objectives of the Green party since the 1980s. Party representatives have always warned about the risks of nuclear disasters, which were called "zero-risk events" by others.

Fourth, we find that immediate policy action can alleviate, or even reverse, concerns in the population. A representative survey conducted on March 14, 2011 found that 70\% of all Germans believed that a nuclear catastrophe similar to Fukushima could also happen in Germany. Accordingly, $71 \%$ were in favor of a complete phaseout of nuclear energy, up from 62\% in August 2010 (Infratest, 2010, 2011a, b). In line with these survey data, SOEP data show that after the announcement and implementation of the Atomausstieg, 
environmental concerns significantly decreased again-by approximately the same share that they had increased after Fukushima. Again, a representative survey conducted in June 2011 underlines these findings, showing that $54 \%$ of all Germans support the complete phaseout of nuclear energy and also the quick political decision process (Infratest, 2011c).

While this study exploits household panel data and provides empirical evidence for three European countries, the focus is on Germany for two reasons: The first, technical reason is that we can use the German Socio-Economic Panel (SOEP, 2012), which is a representative long-running panel study with a rich set of concern, well-being, risk, and political preference questions. As such, we are able to net out individual unobserved heterogeneity in our combined Difference-in-Difference (DID) and Regression Discontinuity (RD) models, sometimes also called Difference-in-Discontinuity (DiDis) models. Specifically, we exploit the exact interview date and the fact that about $50 \%$ of all SOEP respondents were surveyed before and after the Fukushima disaster in 2011. Established in 1984, the SOEP also allows us to directly compare the impact of the Fukushima and Chernobyl disasters using the same data, models, and variables as well as the same institutional and cultural setting. Chernobyl also provides a counterfactual when evaluating the effect of the Atomausstieg.

The second, institutional reason is that the German Atomausstieg as a reaction to Fukushima was worldwide unique. For decades, debates about nuclear energy, especially its risks, costs, and benefits, have been an integral part of the political debate in Germany. A complete nuclear phaseout has always been one of the key policy objectives of the Greens who have been part of the German parliament since 1982.

The findings of this paper are of general interest and not limited to Germany. As in Germany, there have been debates and referenda about nuclear energy in various industrialized countries. Massive protests prevented the Carnsore Point nuclear power plant in Ireland from starting operations in the 1970s. Austria decided to mothball the already finished Zwentendorf nuclear power plant after a negative referendum in 1978. As a reaction to the 1986 Chernobyl disaster, the Philippines decided against operating a new nuclear power plant, while Italy shut down its four operating ones. Currently, there exist 435 nuclear power plants in 30 countries; half of them are located in the USA where nuclear energy is less controversial than in Europe. New reactors are planned in 21 of these 30 countries. Eleven countries that currently do not operate nuclear power plants plan to use nuclear energy in the future, including Turkey, Poland, Indonesia, and Vietnam. On the contrary, in addition to Germany, nuclear energy is being phased out in Switzerland, Belgium, and Spain. Thus, although population attitudes and cultures differ across countries, the German example is informative for a wider set of countries. 


\section{Literature Review}

This paper contributes to several strands in the economic literature (e.g. Benjamin et al., 2014a, b; Bond and Lang, 2014). First, it adds to the literature on well-being. Events studied in this field include economic growth (Oswald, 1997; Oswald and Wu, 2011; Deaton, 2012), unemployment (Winkelmann and Winkelmann, 1998; Kassenboehmer and Haisken-DeNew, 2009; Knabe et al., 2010; Luechinger et al., 2010; Marcus, 2013), (relative) income (Frijters et al., 2004; Senik, 2009; Clark et al., 2009; Clark and Senik, 2010), or pollution (Luechinger, 2009).

Second, the paper adds to the small, but growing, field on the effects of natural disasters, terrorism, and nuclear accidents (e.g. Ekel et al., 2009; Cassar et al., 2011; Shah and Cameron, 2015). For example, Luechinger and Raschky (2009) use subjective well-being measures to economically value the costs of flood disasters. Pesko (2014a, b) assesses the impact of Hurricane Katrina and terrorism on stress and risky behaviors, while Pesko and Baum (2014) assess the impact of 9/11 on similar outcomes. ${ }^{1}$ Draca et al. (2011) study the impact of the 2005 terrorist attacks in London on crime.

While all papers cited above study directly affected populations, several papers study negative externalities and spillover effects on other, presumably unaffected, countries. Such negative externalities and spillover effects provide an economic justification for a supra-national regulation of policies on climate change, counter-terrorism, and nuclear energy. For example, Metcalfe et al. (2011) show that 9/11 negatively affected mental well-being of residents in the UK. Schüller (2012) shows that negative attitudes towards immigration increased in Germany post-9/11.

While Danzer and Danzer (2011) and Lehmann and Wadsworth (2011) find negative long-term effects of the Chernobyl disaster on subjective well-being and (mental) health in Ukraine, three other papers assess the impact of the disaster on a variety of well-being, health, and labor market outcomes in other countries: (i) Almond et al. (2009) find negative long-term effects of prenatal exposure on cognitive abilities in Sweden, (ii) Halla and Zweimüller (2014) find negative long-term effects of prenatal exposure on labor market outcomes in Austria, and (iii) Berger (2010) finds that environmental concerns increased in West Germany immediately after the disaster.

\footnotetext{
${ }^{1}$ Other studies assess the indirect effects of the War Against Terrorism by showing that combat exposure increases (i) risky behaviors, such as smoking or drug use, among affected soldiers (Cesur at al., 2014), as well as (ii) sleep disorders, psychological problems, and the risk of migraine headache (Cesur et al., 2015).
} 
Several studies on the consequences of the Fukushima disaster exist. However, almost all of them focus on Japan (Glaser, 2011; Hippel, 2011; Hommerich, 2012; Huenteler et al., 2012; Kawashima and Takeda, 2012; Thomas, 2012; Uchida et al., 2014; Vivoda, 2012; Yamamura, 2012; Aoki and Rothwell, 2013; Bauer et al., 2013; Buesseler et al., 2012; Csereklyei, 2013; Ohtake and Yamada, 2013; Rehdanz et al., 2013; Richter et al., 2013; Rieu, 2013; Tiefenbach and Kohlbacher, 2013, 2015; Wang et al., 2013; Welsch and Biermann, 2014). Specifically, three (unpublished) studies focus on well-being. ${ }^{2}$ Rehdanz et al. (2013) use household panel data from the Japanese KHPS and find that, post-Fukushima, people living closer to the disaster report lower levels of subjective well-being than people living further away. Hanaoka et al. (2014) exploit the Japan Household Panel Survey on Consumer Preferences and Satisfaction and variation in affected Japanese regions. They find that respondents in more affected regions became more risk tolerant.

Using the SOEP and similar outcome variables as this study, Richter et al. (2013) also investigate the effects of Fukushima and the nuclear phaseout in Germany. However, the two studies differ substantially with respect to the methodological approach. First, Richter et al. (2013) solely use the year 2011 and do not exploit the panel structure of the data, whereas this study nets out individual unobserved heterogeneity through individual fixed effects. Second, Richter et al. (2013) use a simple before-after comparison, whereas this study uses a combined Difference-in-Difference (DID) and Regression Discontinuity (RD) model. Moreover, this study provides empirical evidence on operating channels, with a particular focus on risk aversion and political preferences, while providing heterogeneity analyses and using additional concern and well-being measures. Third, Richter et al. (2013) solely focus on Germany, whereas this study focuses on Germany and two additional countries that differ in their energy policies and in their policy responses. Section 5.2.10 replicates Richter et al. (2013) and highlights some methodological differences to this study.

This paper also adds to the literature on energy economics (Greenstone and Gayer, 2009; Cesur at al., 2013; Strielkowski et al., 2013), political economy (Anderson et al., 2013), and their interplay (Ockwell, 2008; Büscher 2009; Acemoglu et al., 2011; Wangler, 2012). The latter is a growing field that deals primarily with the policies and consequences of renewables and climate change (Cullen, 2013; Pindyck, 2013; Marron and Toder, 2014; Murray et al., 2014).

Finally, this paper contributes to the literature on the determinants and impacts of risk aversion (Lusk and Coble, 2008; Eckel et al., 2009; Cassar et al., 2011; Malmendier and Nagel, 2011; Huang et al., 2013, Hanaoka et al., 2014; Cohn et al., 2015; Vieider et al., 2015; Shah and Cameron, 2015) and environmental

\footnotetext{
${ }^{2}$ In addition to these three studies focusing on well-being, Bauer et al. (2013) study the impact of the shutdown of reactors on housing prices in Germany. They find that housing prices decreased by between 6 and $12 \%$.
} 
concerns. Studies in the latter field find that females and higher educated people are more concerned about the environment (Czap and Czap, 2010; Tatic and Cinjarevic, 2010; Urban and Ščasný, 2012; Aklin et al., 2013). Interestingly, income itself does not seem to play a big role (Tatic and Cinjarevic, 2010; Aklin et al., 2013). Owen at al. (2012) show that personal experiences with extreme weather events, however, positively affect preferences for environmental regulation. ${ }^{3}$

\section{Data}

This study uses household panel data provided by the German Socio-Economic Panel (SOEP) for Germany, the Swiss Household Panel (SHP) for Switzerland, and Understanding Society for the UK, all of which are described in more detail below (Budowski et al., 2001; University of Essex).

\section{SOEP}

The SOEP (2012) is a representative panel study of private households in Germany, conducted annually since 1984. About 20,000 individuals in 11,000 households are surveyed every year. All respondents aged 17 and older answer an individual questionnaire covering about 150 questions on different topics, such as demographic, educational, and labor market characteristics, health, well-being, concerns, attitudes, and perceptions. For further details about the survey content and design, see Wagner et al. (2007).

The baseline specification exploits the panel dimension of the SOEP and focuses on respondents interviewed in 2010 and 2011. In total, the SOEP contains 20,178 person-year observations from 10,177 different individuals which were interviewed in both years and have no missings on their observables. In 2011, roughly half of those 10,177 individuals were interviewed before and after the Fukushima disaster. Since only individuals who were interviewed in both years contribute to the identifying variation in the individual fixed effects models, we routinely use a balanced panel when we use the years 2010 and 2011. The results are, however, robust to employing the unbalanced panel (see Column (4) of Table A7 in the Online Appendix).

\footnotetext{
${ }^{3}$ Table A4 in the Online Appendix shows simple socioeconomic determinants of environmental concerns. The findings largely confirm the previous literature: Relative to the mean share of very environmentally concerned people in the population, which is $31 \%$, environmental concerns are (i) $7 \mathrm{ppt}$ higher among females and (ii) 3ppt higher among disabled individuals, whereas they decrease (iii) by $0.5 \mathrm{ppt}$ for each child in the household, (iv) by $21 \mathrm{ppt}$ for individuals with the lowest educational degree (less than secondary) relative to the highest educational degree (tertiary), and (v) by $6 p p t$ for individuals who are full-time employed relative to being irregularly employed.
} 
For extended analyses, in particular for the analysis of medium-term effects, we use data from 2009 to 2012, obtaining 57,492 person-year observations. Moreover, in a falsification test, we compare Fukushima to Chernobyl. To do so, we exploit the same data, models, and variables but focus on respondents who were interviewed between 1984 and 1989, obtaining 62,540 person-year observations. In these extended analyses with more than two waves of panel data, we routinely use unbalanced panels, as we would otherwise select on a specific subsample of respondents-those not prone to panel attrition-and would potentially discard useful information.

\section{Dependent Variables: Concerns, Well-Being, Risk Aversion, and Political Preferences}

Concerns. We exploit several concern measures that are routinely surveyed by the SOEP. Our first dependent variable is based on the question: "What is your attitude toward environmental protection? Are you concerned about it? (a) Very concerned, (b) Somewhat concerned, (c) Not concerned at all." We collapse the answer to this question into a binary measure that is one when respondents are "very concerned" about environmental protection, and zero otherwise. As seen in the Appendix, 31\% of all respondents are very concerned about the environment. Analogously, we generate binary measures indicating respondents who are "very concerned" about climate change and, for placebo tests, "very concerned" about their job security, health, the economy, and crime (see Appendix).

Well-Being. First, we use the standard 11 categorical life satisfaction measure. It has its mass point between the values 5 and 9 . On average, $86 \%$ of all respondents fall into these categories. The SOEP also measures affective well-being, asking respondents to rate how often they felt happy or sad during the 4 weeks prior to the interview. The five answer categories range from "very seldom" to "very often". We collapse the two highest categories, "often" and "very often" and, accordingly, generate two dichotomous variables. The Appendix shows that (only) $13 \%$ of all Germans are "often" or "very often" happy, whereas $54 \%$ are "often" or "very often" sad. ${ }^{4}$

Risk Aversion. We collapse the standard 11 categorical risk attitude scale-ranging from 0 (extremely risk averse) to 10 (extremely risk loving)-and generate four mutually exclusive risk aversion measures (Dohmen et al., 2011). We categorize respondents in category 0 as "extremely risk averse" (5\%), respondents in categories 0 to 1 as "very risk averse" (10\%), respondents in categories 0 to 2 as "moderately risk averse" (22\%), and respondents in the lowest four categories simply as "risk averse" (37\%).

\footnotetext{
${ }^{4}$ In the empirical models, we take the retrospective nature of these questions into account and use the date 4 weeks after the Fukushima disaster and the policy action as the cutoff dates, i.e., April 11 instead of March 11, 2011, for the Fukushima disaster and June 30 instead of May 30, 2011 for the policy action.
} 
Political Party Preferences. We obtain the binary indicator Supports Political Party from the question that asks respondents "Do you lean towards a particular party?" On average, $49 \%$ of all Germans do. For respondents who answer "yes" to this question, we obtain specific political party measures, such as Supports SPD (30\%), Supports The Greens (15\%), Supports CDU/CSU (40\%), Supports FDP (5\%), and Supports The Left (7\%). ${ }^{5}$ Finally, to understand how intensely respondents support a party, Strong Political Party Support and Weak Political Party Support are generated from the five categorical answers to the question “And to what extent [do you lean towards this party]?". On average, $44 \%$ support a party strongly and $6 \%$ support a party weakly.

Distance to Reactors. By using the exact geographical coordinates of all SOEP households, we exploit the distances between respondents' residencies and the nearest nuclear power plant. As such, we can additionally differentiate the estimated effects to learn more about operating channels. Nuclear power plant distance measures are used for Germany, Switzerland, and the UK.

Figure 2 depicts nuclear power plants in and around Germany along with radii of $25 \mathrm{~km}(16 \mathrm{mi}), 50 \mathrm{~km}$ $(31 \mathrm{mi})$, and $100 \mathrm{~km}(62 \mathrm{mi})$. Three distance variables indicate weather respondents live (i) within $50 \mathrm{~km}$ to reactor ( $28 \%$ of all Germans), (ii) within $50 \mathrm{~km}$ to $80 \mathrm{~km}$ to reactor ( $20 \%$ of all Germans), or whether the (iii) nearest reactor is among the eight oldest (49\% of all Germans). The eight oldest German reactors were temporarily shut down on March 14, 2011 and permanently shut down on May 30, 2011. To account for potential residential sorting based on environmental concerns, we run robustness checks that exclude individuals who moved outside a $50 \mathrm{~km}(31 \mathrm{mi})$ radius of their birth place and individuals who moved previously (see Columns (2) and (3) of Table A6 in the Online Appendix). ${ }^{6}$

\section{[Insert Figure 2 about here]}

\section{Sociodemographic Covariates}

The regression models control for the Demographic Characteristics age, female, and for being married, single, or disabled. In addition, individuals without German nationality and the number of children in the household are indicated. Educational and Labor Market Characteristics measure whether respondents are

\footnotetext{
${ }^{5}$ At the time of the disaster, Germany's parliament comprised five political parties. With $44 \%$ of the votes, the Christian- Democrats (CDU/CSU) and the Free Democratic Party (FDP) formed the governing coalition. The Social Democrats, the Greens, and The Left formed the opposition. Accordingly, we generate a variable "Supports Government."

${ }^{6}$ Traditionally, (inter-generational) geographic mobility is very low in Germany. In a given year, only about $1 \%$ of SOEP respondents move (not shown).
} 
still in education or have a schooling degree, and whether they are full-time employed, part-time employed, out of the labor force, on maternity leave, or unemployed. The full descriptive statistics for Germany, Switzerland, and the UK are in the Appendix.

\section{Empirical Model and Identification}

To the extent that our dependent variables are binary, we run Linear Probability Models (LPM). ${ }^{7}$ Specifically, we employ the following model:

$$
\begin{aligned}
y_{i t}= & \text { B }_{0}+\text { B }_{1} \text { PostMarch11 }_{i, 2011} * 2011+\text { B }_{2} \text { PostMay30 }_{i, 2011} * 2011+ \\
& + \text { b }_{3} \text { PostMarch11 }_{i, 2011}+\text { B }_{4} \text { PostMay30 }_{i, 2011}+X_{i t}{ }^{\prime} \gamma+\delta_{y}+\varphi_{m}+t+\varepsilon_{i t}
\end{aligned}
$$

where $y_{i t}$ represents the dependent variable for individual $i$ at time $t$. PostMarch $11_{i, 2011}$ is a dummy variable that indicates whether a respondent's interview in 2011 occurred after or on March 11-the day of the Fukushima disaster. Note that this dummy is time-invariant and indicates the treatment group. This means that all respondents who were interviewed after or on March 11 (in 2011) always have a one on this variable regardless of when they were interviewed in the other years. Consequently, this variable nets out potentially existing systematic differences between respondents who were interviewed before and after March 11, 2011.

PostMay $30_{i, 2011}$ is similarly constructed and stands for the day when the government officially announced the Atomausstieg, permanently shutting down the eight oldest reactors in Germany and phasing out the remaining ones. The coefficients of the interaction terms between PostMarch $11_{i, 2011}$, PostMay30, 2011, and the year 2011, $\boldsymbol{B}_{1}$ and $\boldsymbol{B}_{2}$, measure the Average Treatment Effects on the Treated (ATT). Since the model combines a sharp discontinuity with differences between individuals over time, it can be seen as a combined Difference-in-Difference (DID) and Regression Discontinuity (RD) model, sometimes also called Difference-in-Discontinuity (DiDis) model.

All models routinely control for year and month fixed effects, $\delta_{y}$ and $\varphi_{m}$, a linear time trend, $t$, and a vector of socioeconomic characteristics, $X_{i t}$. A more refined version of the model above (which already exploited the panel structure through the time-invariant dummy variables PostMarch11, 2011 and PostMay30, 2011), is to explicitly consider individual fixed effects via $\mu_{i}$. In doing so, we net out individual unobserved

\footnotetext{
${ }^{7}$ The results are robust to running Logit Models with marginal effects instead of Linear Probability Models. The results are available upon request.
} 
heterogeneity, which is a key methodological difference to Berger (2010) and Richter et al. (2013). Robustness checks augment the baseline model with split time trends in addition to individual fixed effects:

$$
\begin{aligned}
& y_{i t}=B_{0}+B_{1} \text { PostMarch11 }_{i, 2011} * 2011+\text { B }_{2} \text { PostMay30 }_{i, 2011} * 2011+ \\
& t^{*} \text { PostMarch11 } 1_{t, 2011}+t^{*} \text { PostMay30 } 0_{t, 2011}+X_{i t}{ }^{\prime} \gamma+\delta_{y}+\varphi_{m}+\mu_{i}+\varepsilon_{i t}
\end{aligned}
$$

Note that when including individual fixed effects, the time-invariant dummy variables PostMarch11 1,2011 and PostMay30 $\mathrm{i}_{\mathrm{i}, 2011}$ drop out of the estimation.

\subsection{Identification of the Fukushima Effect}

The main identifying assumption is that, conditional on the vector of socioeconomic characteristics, $X_{i t}$, year and month fixed effects, $\delta_{y}$ and $\varphi_{m}$, the linear time trend, $t$, and conditional on netting out individual unobserved heterogeneity, $\mu_{i}$, the interview date is exogenous to the Fukushima disaster. It is very likely that this identifying assumption holds.

The Fukushima disaster happened on March 11, 2011. Most SOEP interviews are carried out during the first 6 months of the year. ${ }^{8}$ Hence, in 2011, roughly half of all SOEP respondents completed their interviews before and after March 11. Table A1 plots the mean values of all covariates along with their scale-free normalized differences. Imbens and Wooldridge (2009) suggest that a normalized difference above 0.25 indicates covariate imbalance. This is not the case for any of our covariates. Thus, we conclude that the sample is well-balanced on observables. ${ }^{9}$ Note that even systematic differences in observables and unobservables would not necessarily be a threat to the identification strategy. First, we control for observables. Second, the time-invariant variable PostMarch11, 2011 nets out systematic differences between respondents before and after the exogenous event. Moreover, since we use panel data and focus on a relatively short time horizon, our individual fixed effects models net out time-invariant individual unobserved heterogeneity. In fact, our estimates vary little depending on the approach employed which reinforces the exogeneity as-

\footnotetext{
${ }^{8}$ In practice, the fieldwork company that carries out the interviews assigns each interviewer two to three tranches of respondents with addresses to schedule and conduct interviews over a defined time period of a couple of months. Within that time period, each interviewer coordinates the specific interview independently with the respondent. This approach guarantees a relative balancedness of interviewee characteristics over the year.

${ }^{9}$ We also checked the covariate balance with respect to the May 30 and June 30, 2011, cutoff dates for the policy action. Again, none of the normalized differences exceed the threshold of 0.25 . The results are available upon request. In addition, we calculated the normalized differences and means for the important outcome variable "environmental concerns" by the policy dates May 30 and June 30 in 2010. We find that, if anything, respondents interviewed later in the year report higher levels of environmental concerns. For the May 30 cutoff date, the mean levels are 0.29 (pre) and 0.32 (post), whereas they are 0.30 (pre) and 0.32 (post) for the June 30 cutoff date. The differences are, however, not statistically significant and the normalized differences are below 0.05 in both cases.
} 
sumption of the interview date. Finally, it is difficult to think of an unobservable that systematically affected the outcomes in 2011, but not in 2010, and was correlated with the date of Fukushima. Basically, this would be an event that is unrelated to but strongly correlated with Fukushima, which-to the best of our knowledge-did not exist.

It is, however, important that self-administered interviews were not systematically postponed due to the Fukushima disaster. In fact, the Fukushima disaster happened on a Friday at 7:45am CEST. Interviews where an interviewer is physically present are typically scheduled several days in advance. It is conceivable, though unlikely, that (environmentally sensitive) respondents postponed their scheduled interviews. Even if this happened, it would not bias the disaster estimates since interviews carried out on or after March 11 fall into the treatment group. Comparing the distribution of interviews (excluding self-administered interviews) carried out on Fridays to the interviews carried out on Friday March 11, 2011, we find no abnormal decrease. ${ }^{10}$ Additionally, in robustness checks, we exclude all interviews that were not scheduled and where a trained interviewer was not present (see Table A5 and Column (4) of Table A6 in the Online Appendix). In another robustness check, we exclude March 11 interviews which does not affect the estimates either (results not shown).

Since the Fukushima disaster was exogenous to interview dates, in principle, an adjustment for prepost differences in the sample composition is not necessary. ${ }^{11}$ In a totally randomized setting, one could rely on cross-sectional data to estimate the effect of the disaster. The use of panel data allow us to compare (i) LPM treatment effects unadjusted for observables with (ii) LPM treatment effects adjusted for observables, as well as (iii) pooled LPM-OLS estimates not exploiting the panel structure with (iv) LPM-FE estimates eliminating individual unobserved heterogeneity. Comparing (i) with (iv) serves as a robustness check for the disaster date exogeneity assumption and yields information on potential confounding factors.

\subsection{Identification of Nuclear Phaseout Effect}

Compared to the identification of the disaster effect, the identification of the nuclear phaseout effect is more challenging for a number of reasons: First, we observe a series of policy events rather than a single event (see Figure 1). The initial event, the Atommoratorium, which temporarily shut down the eight oldest

\footnotetext{
${ }^{10}$ On March 11, 2011, 80 interviews were carried out, the week before 81, the week after 64, and on the last Friday of March, 78 interviews were conducted.

${ }^{11}$ As a referee correctly pointed out, there may be unobserved third factors that vary systematically across seasons and may affect environmental concerns, e.g., air pollution. Ziebarth et al. (2014) show that between 1999 and 2008 pollution patterns follow very regular seasonal patterns in Germany. Unless there was an unusual and longer-term spike in air pollution exactly at the time of Fukushima, monthly fixed effects should net out seasonal pollution effects.
} 
reactors, was announced and implemented on March 14, 2011, only 3 days after the Fukushima disaster. Empirically, it is basically impossible to disentangle the effect of the Atommoratorium from the disaster. One could hypothesize that its impact may have operated in both directions-either reinforced or reduced environmental concerns. When estimating the models with March 14 as the relevant policy action date, the coefficients barely change, which could suggest that the Atommoratorium had little impact on Germans' concerns. ${ }^{12}$ Hence, we consider the unexpected and widely covered announcement of the Nuclear PhaseOut Bill on May 30, 2011 as the crucial policy action date.

Second, a decrease in media coverage and thus disaster-related consciousness in the population may have reduced environmental concerns. We provide the following robustness checks that support our view that the unexpected and drastic turnaround in energy policy contributed significantly to the decrease in environmental concerns: Figure 3a plots the results of a Google trend search using the three German keywords Energy Transition (Energiewende), Alternative Energies (Alternative Energien), and Renewable Energies (Erneuerbare Energien). Figure 3b shows the relative search volume for the Solar Energy (Solarenergy), Wind Energy (Windenergie), Photovoltaics (Photovoltaic), and Water Power (Wasserkraft). Google trend search has been shown to have good predictive power for economic indicators (Askitas and Zimmermann, 2012; D'Amuri and Marcucci, 2012). The graphs clearly show two main developments: (a) Immediately after Fukushima, the search volume spiked. (b) In the subsequent week(s), it sharply decreased, but remained relatively stable at a level clearly higher than before Fukushima. The latter point is crucial and shows that, in our opinion, it is extremely unlikely that the entire decrease in environmental concerns can be traced back to a decrease in media coverage and thus disaster-related consciousness in the population. Moreover, recall that due to the incompetent management of the catastrophe by Tokyo Electric Power Company (TEPCO) -the operating firm of the Fukushima Daiichi nuclear power plant-Fukushima and nuclear safety remained in the media spotlight for a very long time.

\section{[Insert Figure 3 about here]}

Figure 5 shows that the decrease in environmental concerns started to kick in about 6 weeks after the disaster before the announcement of the Nuclear Phase-Out Bill. This may be attributed to or reflected by the decrease in search volume observed in Figure 3. However, Figure 5 also shows a clear, structural, and additional decrease in environmental concerns below the zero $y$-axis line immediately after May 30, which is of a similar magnitude as the increase after March 11. Recall that, among others, the empirical

\footnotetext{
${ }^{12}$ We also tested whether the release of the report of the Reactor Safety Commission on May 17, 2011 (the so-called Reaktorsicherheitskommission), which gave a rather negative safety outlook for German reactors, had any impact on environmental concerns, but do not find any evidence for that.
} 
models routinely control for month fixed effects, linear time trends, and individual time-invariant unobserved heterogeneity. Moreover, we run a series of placebo regressions with alternative policy action dates in 2011 and 2010. We also show that the findings are robust to the inclusion of separate linear time trends after the disaster and the policy action, as well as to the inclusion of a quadratic time polynomial. A simple "return-to-the-baseline" effect would be captured by these controls.

Finally and importantly, we use the same data, models, and variables to assess the medium to longrun effects of the Chernobyl disaster in 1986. This falsification test uses July 15, 1986 (e.g., 81 days after Chernobyl) as a placebo nuclear phaseout date. We find that (a) environmental concerns were still significantly elevated at the end of 1986 and (b) there is no significantly negative effect of the placebo nuclear phaseout date on environmental concerns. Concerns that Chernobyl and Fukushima cannot be compared due to different media coverage and exposure can be dismissed by Figure 4. Figure 4 shows the number of newspaper articles with the keywords "Fukushima" and "Chernobyl" in one of the leading (internationally available) German newspapers, Frankfurter Allgemeine Zeitung (FAZ). The normalized graph impressively shows that the spike and subsequent decrease in media coverage was almost perfectly identical in 2011 and 1986. Thus, we consider Chernobyl as a valid counterfactual.

\section{[Insert Figure 4 about here]}

In sum, one can say that the identification of the effect of the policy action is challenging and likely confounded by a decrease in media coverage. However, a series of robustness checks suggests that part of the significant and surprisingly large decrease in environmental concerns can be explained by the unexpected and drastic energy policy turnaround by the center-right German government.

\section{Results}

\subsection{Descriptives}

Figures $A 1,5$, and 6 anticipate and illustrate one of our main findings. Figure A1 in the Online Appendix is a nonparametric representation of an unbalanced OLS model, and Figures 5 and 6 are nonparametric representations of a model with individual fixed effects. The $x$-axes display the interview dates in 2011; the first black vertical bar indicates the Fukushima disaster and the second vertical black bar indicates the announcement of the Nuclear Phase-Out Bill.

Figure A1 plots the share of respondents, on a given day, who reported being very concerned about the environment. We observe a distinct jump in this share after the Fukushima disaster. After the announce- 
ment of the Nuclear Phase-Out Bill, however, the share decreased again. Note that the grey underlined confidence intervals widen towards the end of the year, as only $10 \%$ (or 1,100) of all interviews were carried out after August 1, 2011.

Figure 5 exploits the panel structure of the data. The $y$-axis displays the individual-level change in responses between the 2011 and 2010 interviews, where the 2011 interview determines the location on the $y$-axis. In other words, Figure 5 plots the change in the daily share of people who are very concerned about the environment by their 2011 interview date, relative to their 2010 answers. This is the graphical representation of a Difference-in-Discontinuity (DiDis) model, which exploits the combination of a sharp discontinuity with differences between individuals over time.

\section{[Insert Figures 5 and 6 about here]}

Figure 5 illustrates that, while there was zero change in environmental concerns before the Fukushima disaster, environmental concerns significantly increased by 5 to $10 \mathrm{ppt}$ thereafter. They started to decline smoothly again after about 6 weeks. However, after the conservative government announced the Nuclear Phase-Out Bill, making a sharp and unexpected U-turn in their energy policy, environmental concerns significantly and sharply decreased once more, now falling below the horizontal zero-change line on the $y$-axis.

Figure 6 is set up analogously to Figure 5, but plots changes in life satisfaction. It is easy to see that the curve is flat around the zero-change line on the $y$-axis. No changes in life satisfaction that could be attributed to the disaster or the policy action are observable.

\subsection{Regression Results}

\subsubsection{Baseline Specifications}

Table 1 shows our baseline specifications, where we focus on just 2 years, 2010 and 2011. The first two columns estimate OLS-LPM and the next two columns FE-LPM models. ${ }^{13}$ Thus, the first two columns are the (covariate-adjusted) regression equivalent to Figure $\mathrm{A} 1$, and the last two columns are the (covariate-adjusted) regression equivalent to Figure 5 . The binary dependent variable is environmental concerns and indicates whether respondents are "very concerned" about environmental protection. For the sake of clarity and brevity, we suppress the coefficient estimates of those covariates that are not of principle interest; these can be found in Table A4 of the Online Appendix. As shown in the bottom of Table 1, in the even

\footnotetext{
${ }^{13}$ We routinely cluster standard errors at the interview date level (Bertrand et al., 2004, Lee and Card, 2008). However, clustering at the household or state level does not alter the results. The results are available upon request.
} 
numbered columns covariates, $\mathrm{X}_{i t}$, are included in the regressions, whereas they are excluded in the odd numbered columns. We learn the following from Table 1 :

\section{[Insert Table 1 about here]}

First, across all four models, we consistently find that environmental concerns significantly increased by about 7ppt immediately after the Fukushima disaster. Relative to the baseline level of environmental concerns before Fukushima, this represents an increase of about $23 \%{ }^{14}$

Second, after the sharp and unexpected U-turn in energy policy-the permanent shutdown of the eight oldest reactors and the announcement of the Nuclear Phase-Out Bill-environmental concerns decreased significantly by about 10ppt. Relative to the baseline level of environmental concerns between March 11 and May 30, which was $38 \%$, this represents a decrease by about $26 \%$, i.e., a decrease that roughly equals the increase immediately after Fukushima. Obviously, the Nuclear Phase-Out Bill helped to counterbalance environmental concerns triggered by the Fukushima catastrophe. Note that, in our preferred specification, we routinely employ year fixed effects, month fixed effects, a linear time trend, and individual fixed effects. Since we also reply on sharp timely variation, the effects are identified by changes in respondents' environmental concerns from 2010 to 2011-net of monthly shocks and a time trend-for the treatment group that was interviewed just after the exogenous disaster, relative to the control group that was interviewed just before the disaster. This identification approach can also be interpreted as a DiDis model (see Section 4.1).

Third, we find no evidence that (i) respondents differ in their observables before and after the March 11 and May 30 interview dates (see Table A1), (ii) the correction for observables matters, and (iii) the correction for unobservables matters. Across all models, the estimates remain almost identical whether or not we include covariates, $\mathrm{X}_{i t}$. The OLS vs. FE estimates are likewise almost identical.

As discussed in detail below, the Online Appendix provides batteries of robustness checks including specifications that test the exogeneity of the interview date and employs several variants of time trends as well as placebo policy and Fukushima dates.

\footnotetext{
${ }^{14}$ When using March 14 as disaster date, the results remain largely robust. The results are also robust to collapsing the three categorical environmental concern question differently. When we run the same models but collapse the categories "somewhat" and "very concerned", we find that the share of at least "somewhat" concerned Germans increased by $2 \mathrm{ppt}$ from a baseline level of $89 \%$ after Fukushima. The results are available upon request.
} 


\subsubsection{Effects on Measures of Subjective Well-Being}

Life Satisfaction. The first column of Table 2 uses the standard 11 categorical life satisfaction measure as dependent variable. This model is the regression equivalent to Figure 6. As already suspected in Figure 6, we do not find any evidence that the disaster or the phaseout had an effect on life satisfaction. Typically, studies consistently find that individual income or unemployment have strong effects on life satisfaction (Winkelmann and Winkelmann, 1998; Frijters et al., 2004; Kassenboehmer and Haisken-DeNew, 2009; Knabe et al., 2010). One may interpret our finding as evidence that disasters may affect specific individual concerns, even in distant geographical regions, but not satisfaction with life in general, at least as long as individuals are not directly affected. This is in line with Berger (2010) and with the empirical evidence from the UK and Switzerland (see below).

\section{[Insert Table 2 about here]}

Happiness. The finding from Column (1) is reinforced in Column (2) where we make use of a collapsed version of the "happiness" affective well-being measure (see Section 3). We do not find evidence that the share of people who felt "very often" or "often" happy changed significantly as a result of the disaster or the policy action.

Sadness. In contrast, after Fukushima, the share of respondents who felt "sad" increased by about $5 p p t$ (Column (3)). This is understandable, as the magnitude of the disaster affected people around the globe emotionally. This may be reflected in column (3).

Concerns about Climate Change. The sharp and unexpected U-turn in the energy policy entailed a long-term, large-scale plan under which Germany would gradually replace nuclear with renewable energy. Angela Merkel created the term "Energy Transition" (Energiewende) for this ambitious plan. Since the Energiewende is inherently linked to climate change politics and was largely communicated to the public with this spin, column (4) tests whether concerns about climate change shifted. Indeed, concerns about climate change significantly increased after the Fukushima disaster but significantly decreased after the policy action, which entailed the announcement of the Energiewende. ${ }^{15}$

\footnotetext{
${ }^{15}$ There are several explanations for why climate change concerns significantly increased after Fukushima: (1) It could simply be that the environmental disaster raised people's awareness about environmental issues, (2) In the short run, shutting down nuclear power plants means replacing the energy production largely with climate-damaging fossil energy, and/or (3) individuals might be confused that nuclear energy and emissions have not been linked to climate change.
} 


\subsubsection{Effects on Risk Aversion and Evidence on Operating Channels}

\section{Impact on the German Risk Aversion Distribution, or: Does Merkel Represent German Attitudes?}

Next, we test whether Germans became more or less risk averse after the Fukushima disaster. The quote by Chancellor Merkel above strongly suggests that she became more risk averse; at least she declared many times in public that, before Fukushima, she believed that the remaining risk of a nuclear accident was zero but that she re-assessed her opinion and changed her mind and willingness to tolerate small high-stakes risks (Bundesregierung, 2012a).

\section{[Insert Table 3 about here]}

Table 3 provides tests on the entire risk aversion distribution. We employ four different binary outcome variables that represent collapsed versions of the right tail of the risk aversion distribution. In other words, we test whether the share of Germans who self-categorized as risk averse (0-3/10 on scale), moderately risk averse (0-2/10 on scale), very risk averse (0-1/10 on scale), or extremely risk averse (0/10 on scale) changed after the meltdown and the nuclear phaseout.

As seen, while there is little evidence that more Germans self-categorized as a 3 or 2 on a scale from 0 to 10 , the empirical models show a movement into the very right tail of the risk aversion distribution. This means that more Germans self-categorized as a 1 or even a 0 on the risk assessment scale. Immediately after Fukushima, the share of "very risk averse" people increased by $1.6 \mathrm{ppt}$ from a baseline of $10 \%$, and the share of "extremely risk averse" people increased by $2 \mathrm{ppt}$ from a baseline of $5 \%$. After it became certain that the oldest nuclear reactors would remain permanently shut down and that the remaining ones would be shut down in the future, extreme risk aversion decreased again to the pre-Fukushima baseline level. Finally, in Table A10, we demonstrate that netting out unobserved individual heterogeneity via individual fixed effects matters for risk aversion. The unbalanced OLS models show attenuated and insignificant effects, while focusing on changes in risk aversion for the same individuals over 2 years yields larger and more precisely estimated effects. This finding is in line with Hanaoka et al. (2014).

\section{Do Risk Aversion and Concern Effects Differ by Exogenous Distances to Reactors? Operating Channels.}

Now, we exploit the exact distances between respondents' residencies and the nearest nuclear power plant, as illustrated in Figure 2. The idea is to stratify the risk aversion and concern results by exogenous distance indicators to learn more about operating channels. While people may sort into or out of close proximity to nuclear plants based on their preferences, the exogenous nature of the disaster is very likely 
uncorrelated with such endogenous residential sorting in the short run. We exploit this fact below in Tables 4 and 5 . The exogeneity assumption would be violated if a significant share of respondents deliberately moved away from or towards a nuclear power plant in the months after the Fukushima disaster. We run robustness checks to test for endogenous residential sorting by excluding movers. ${ }^{16}$

Technically, in Tables 4 and 5, we add distance indicators both in levels and as interaction terms with PostMarch11 ${ }_{i, 2011} * 2011$ and PostMay30 $i, 2011$ 2011. As discussed in Section 3, we generate three distance indicators, within $50 \mathrm{~km}$ to reactor, within $50 \mathrm{~km}$ to $80 \mathrm{~km}$ to reactor, and nearest reactor among eight oldest. In addition to the three-way interaction terms, we also add the corresponding two-way interactions terms to the model, i.e., [variable of interest] ${ }^{*} 2011$, [variable of interest] ${ }^{*}$ PostMarch11 ${ }_{i, 2011}$, and [variable of interest ${ }^{*}$ PostMay30 ${ }_{i, 2011}$. Note that, since we also include individual fixed effects, the distance indicators in levels drop out when excluding movers, and are only identified by movers otherwise. Also note that we consistently include lagged distance indicators.

A priori, one could hypothesize that the Fukushima disaster changed respondents' risk perceptions and environmental concerns via altering their subjective assessment of

(i) the probability of a nuclear disaster outside of Germany or

(ii) the probability of a nuclear disaster inside of Germany.

Finally, one could hypothesize that the

(iii) perceived risk did not change, but people adjusted the degree to which they are willing to tolerate these risks due to Fukushima, i.e., they became more or less risk averse.

Empirically, it is very challenging to unambiguously discriminate between these channels as there is evidence that concern and risk perception may be distinct phenomena-especially in case of concerns about nuclear accidents (Slovic, 1987; Sjöberg, 1998). Obviously, the findings in Table 3 reinforce hypothesis (iii), as does the quote of Angela Merkel.

\section{[Insert Table 4 about here]}

\footnotetext{
${ }^{16}$ In columns (2) and (3) of Table A6 in the Online Appendix, we show that the main results are robust to excluding individuals who live outside a $50 \mathrm{~km}$ radius of their birth place and individuals who moved in the previous time period.
} 
Column (1) of Table 4 investigates the risk aversion results for respondents who live within $50 \mathrm{~km}$ distance to the next nuclear power plant. ${ }^{17}$ Column (2) stratifies on respondents who live between 50 and $80 \mathrm{~km}$ distance to the next plant. And column (3) stratifies on respondents whose closest reactor is among the eight oldest that were immediately (but at that time only temporarily) shut down on March 14 and then permanently shut down on May 30, 2011.

The findings show that respondents who live within a $50 \mathrm{~km}$-radius of nuclear reactors were those who became more risk averse. Post Fukushima, they were much more likely to indicate the risk aversion categories 0 or 1 on a scale from 0 to 10. After the phaseout, their subjective risk aversion level shifted again, now away from the right tail. This finding is reinforced by the fact that the subsequent decrease in risk aversion is driven by respondents whose next reactor was one of the eight oldest. This subgroup saw an increase in risk aversion after Fukushima and then experienced a decrease when it became clear that their next reactor would remain permanently shut down.

The finding that individuals' general risk aversion depends on the degree of local risk factors is fascinating. Although the exact interpretation hinges on what exactly the SOEP risk aversion scale measures (cf. Dohmen et al., 2011), the finding provides evidence for the validity of both hypotheses (ii) and (iii). It may also be seen in stark contrast to Hanaoka et al. (2014) who estimate post-Fukushima changes in risk preferences for Japan and who differentiate the effects by affected regions. They show that (directly) affected individuals became less risk averse after the disaster.

To make sense of the diverging results, it is important to keep in mind that-as compared to Germanythe institution of nuclear energy is deeply embedded in Japanese society. First, from a political party perspective, anti-nuclear energy campaigns have no tradition in Japan (apart from support by the Communist party). Until Fukushima, Japan did not even have a Green party. Second, from a geopolitical perspective, nuclear energy is much more important to Japan than it is to Germany. Unlike Germany, Japan is not embedded in a political economic union such as the EU and wants to maintain an independent energy supply. Further, since Fukushima, the massive imports of fuel and liquid gas wear heavy, not only on Japan's trade deficit but also on its image as a leading player in the development of "clean, $\mathrm{CO}_{2}$-free" energy. Many Japanese believe an energy policy without nuclear energy would be unrealistic. This opinion is supported by recent survey data: only $15 \%$ of Japanese citizens support a nuclear phaseout, whereas $71 \%$ of all Germans do (World Nuclear Association, 2015).

\footnotetext{
${ }^{17}$ The results are robust to alternate cutoff radii.
} 


\section{[Insert Table 5 about here]}

Table 5 repeats the exercise to stratify the Fukushima and policy effects by the respondents' distance to the nearest power plant, but this time, we use concern levels as outcome variable. We see again that respondents who lived close to one of the oldest reactors were not significantly more concerned after Fukushima (as compared to the general population) but significantly less after the policy decision to not power up the oldest reactors again. Respondents in 50 to $80 \mathrm{~km}$ (31 to $50 \mathrm{mi}$ ) distance to the next nuclear plant reacted significantly stronger in both directions after Fukushima and the phaseout. ${ }^{18}$ Here, the reactions are not only a function of the distance to the next plant but also of the temporary vs. permanent shutdown of the oldest reactors. Overall, the findings in Table 5 underline those in Table 4 and suggest that local environmental risk factors matter, at least after important events that are related to these local risk factors.

To summarize and reiterate, the differential risk aversion, scaring, and relieving effects strongly speak in favor of hypotheses (ii) and (iii) above. The operating channels through which distant disasters affect individual's concerns appear to work primarily through the (re-)evaluation of local risks and an adjustment in the willingness to tolerate small risks with high stakes. Further evidence is provided by representative polls which indicate that, immediately after the Fukushima disaster, $70 \%$ of Germans believed that Fukushima could also happen in Germany, whereas, in July 2009, some 44\% indicated "trust" or "big trust" in the safety of reactors in Germany (Infratest, 2009, 2011b).

\section{Concern Effect Heterogeneity by Sociodemographics.}

Next, in Table 6, we investigate effect heterogeneity by sociodemographics. We stratify the concern levels in our preferred specification in column (4) of Table 1 by being risk averse, being female, being above 40 years old, and being a Green party supporter. Table 6 provides clear and strong evidence that women (i) incurred an about 4ppt greater scaring effect after the disaster and (i) an about $6 p p t$ greater relieving effect after the policy action as compared to men. However, we fail to find differential treatment effects by age and for risk aversion (columns (1) and (3)). The latter point is interesting in light of the discussion about the conceptual idea behind risk aversion as compared to concerns. Our finding that changes in concern levels and risk aversion are not correlated, while the geographic distance matters for both, supports the hypothesis that concerns and risk perception may indeed be distinct phenomena (Slovic, 1987; Sjöberg, 1998).

\footnotetext{
${ }^{18}$ The fact that we do not find differential effects for those in close proximity, with less than $50 \mathrm{~km}$, may be explained by concern level-based sorting into residencies close to nuclear plants. In extended analyses not displayed, we stratify by the following three measures: (a) whether the closest nuclear power plant will be shut down before 2022 and (b) whether the closest nuclear power plant will not be shut down (exploiting the fact that some Germans live in close distance to nuclear power plants in France and Switzerland, which are not affected by the policy action in Germany). However, we do not find evidence for differential effects by (a) and (b). The results are available upon request.
} 


\section{[Insert Table 6 about here]}

Column (4) of Table 6 shows the effects for Green party supporters. Those are presumably individuals who are strongly in favor of a nuclear phaseout and have always warned about the dangers of a nuclear accident and its consequences. Green party supporters are also known for their high environmental consciousness. We find that-in contrast to the general population-immediately after Fukushima, their concern levels did not significantly increase. Since those individuals were always concerned about nuclear accidents and had always high environmental concern levels, they obviously were not particularly surprised by Fukushima. In contrast, after the sharp turnaround in conservatives' attitudes towards nuclear energy and the unexpected phaseout decision, Green supporters were significantly more relieved than the rest of the population. In fact, (female) Green supporters are driving the observed phaseout relief effect.

\subsubsection{Effects of Fukushima on Political Party Support}

We now take the last findings a step further and exploit a rich battery of political support questions in the SOEP. To be precise, we generate nine political support outcome variables as discussed in Section 3. Those measures are used as dependent variables in a regression framework as in equation (1) along with individual fixed effects. That is, we run the model in column (4) of Table 1 with the outcome variables as indicated in the column headers of Table 7.

\section{[Insert Table 7 about here]}

Column (1) shows no evidence that overall political party support changed after Fukushima or the phaseout decision. For individuals who support a political party, columns (2) to (6) test whether support for the six parties that are represented in the German parliament Bundestag increased or decreased. In line with anecdotal evidence and intuition, after Fukushima, support for the Green party-whose main political objective has always been the phaseout of nuclear energy-significantly increased by about 1.8ppt from a baseline level of 15\%. The pro-nuclear Free Democratic Party (FDP) lost about 1ppt from a low baseline of $5 \%$, and the center-left Social-Democrats (SPD) lost about 1ppt from a baseline of 30\%. There was no significant movement for the other parties, i.e., the center-right CDU/CSU and the far left party "The Left."

In sum, the Greens gained voter sympathies mostly from the center-left voter spectrum, while the pronuclear FDP lost support. This finding is in line with actual election outcomes in two German states. In Baden-Württemberg, a prosperous traditionally conservative state in the south of Germany, a state election was held on March 27, 2011, i.e., two weeks after Fukushima. In this election, the Greens doubled their voter shares by $12.5 \mathrm{ppt}$ and became the second biggest party with $24.2 \%$ of the total votes. They gained 
over proportionally from former SPD voters and non-voters (Tagesschau, 2011). In Rheinland-Pfalz, elections also took place on the same day and the Greens gained 10.8ppt from a baseline of $4.6 \%$.

While our empirical specifications do not suggest that support for parties in general increased-i.e., the extensive margin remained stable-the last two columns of Table 7 provide evidence that there was movement on the intensive margin. In other words, people who were already politically interested and in favor of a political party intensified their support after Fukushima, at least according to self-reports in the SOEP. We also find some evidence that the government may have slightly benefited from the decision to pass a phaseout bill quickly.

\subsubsection{Well-Being and Green Party Effects By Distances To Reactors in Switzerland and the UK}

As a last exercise, we test whether and how residents in Switzerland and the UK reacted to the Fukushima disaster (there was no comparable policy action in any of these countries). To do so, we exploit the panel data sets Understanding Society and the Swiss Household Panel (SHP). The results are presented in Tables $8 \mathrm{a}$ and $8 \mathrm{~b}$. For both countries, we exploit the exogenous timing of the disaster alone and in combination with respondent' distances to the nearest reactor. Dependent variables measure well-being and support for the Green party. ${ }^{19}$ Maps of the UK and Switzerland along with the location of their nuclear reactors are in Figures 7 and 8. The descriptive statistics for the UK and Swiss are in the Appendix, and the models that we run are essentially identical to equation (1). Tables A2 and A3 of the Online Appendix show the means of the covariates separately for pre- and post-March 11 interview dates along with the normalized differences. As for Germany, there is not much evidence for a significant covariate imbalance. All normalized differences are well below 0.25 .

Table 8a shows the results for Switzerland which borders Germany and operates four nuclear power plants (see Figure 7). The uneven columns only show the main effect for PostMarch11, 2011 2011 , and the even columns additionally stratify on the distance to the next reactor. The first two columns exploit life satisfaction as an outcome variable, the next two columns supports the Greens, and the last two columns a binary variable which indicates whether respondents value environmental protection higher than economic growth. While not perfectly comparable, the latter variable is similar to the one surveyed in Germany.

\section{[Insert Table 8a as well as Figures 7 about here]}

\footnotetext{
${ }^{19}$ Unfortunately, we cannot exploit risk aversion measures for the UK and Switzerland since they were only surveyed for one cross section (that also only includes very few post-Fukushima respondents) in both countries (and we show that addition of individual fixed effects matters in Tab A10, also see Hanaoka et al., 2014).
} 
In line with the findings from Germany, there is no evidence that life satisfaction was negatively affected by the disaster (columns (1) and (2)). Contrarily, and again in line with the findings from Germany, voter sympathies for the Greens increased by a significant $2.6 \mathrm{ppt}$ and particularly among respondents who live within 25-50 km of nuclear reactors (column (4)).

Finally, the share of respondents who value environmental protection more than economic growth increased by a significant 1.9ppt over the entire year (Column (5)). The latter finding reinforces that the policy action in Germany significantly contributed to the decrease in environmental concerns in $2011 .{ }^{20}$ Recall that for Germany and 2011, we find a significant decrease in environmental concerns following the Nuclear Phase-Out Bill, resulting in a level of environmental concerns at the end of 2011 (and in 2012) that was not significantly higher than before Fukushima (see Figure 5 and Tables 1 and 9 below).

\section{[Insert Tables $\mathbf{8 b}$ as well as Figure 8 about here]}

Table 9 provides the effects for the UK, for the main model and the refined version where we stratify on the distance to the next nuclear reactor (Figure 8). Once more, we do not find evidence that happiness changed after Fukushima, neither in the UK as a whole nor for people living in close proximity to plants. However, as for Germany and Switzerland, Green voter support increased by a significant 2.6ppt among UK residents who lived in close distance to a reactor (column 4). Finally, including May 30 as placebo phaseout date shows that the effects for the UK are small and insignificant in size.

\subsubsection{Robustness Checks}

Tables A6 to A8 in the Online Appendix provide a series of robustness checks for our standard estimate for Germany, which is the fixed effects model in column (4) of Table 1. In our baseline specifications, we chose the date when the Nuclear Phase-Out Bill was unexpectedly announced by the hitherto pro-nuclear conservative government, May 30, 2011. However, the parliament in Germany formally passed the bill with a great majority of $513 / 600$ votes on June 30,2011 . In column (1) of Table A6, we employ this alternative policy date which delivers robust results.

\footnotetext{
${ }^{20}$ Note that environmental concerns were only surveyed in waves 11 and 13 of the SHP. Since respondents of each wave are interviewed between September and February, the models are essentially comparing individual responses between September 2009 and February 2010 to responses between September 2011 and February 2012. The employed fixed effects models net out individual unobserved heterogeneity and solely focus on changes in the responses between these two waves. Understanding Society does not include environmental concerns which is why we cannot test if they remain elevated for the UK.
} 
Column (2) excludes individuals who live outside a $50 \mathrm{~km}$-radius of their birthplace, and column (3) excludes individuals who moved in the previous time period. Excluding movers, in particular those individuals who moved away from their birthplace, eliminates potential endogenous residential sorting into different regions based on environmental concerns. The results are robust.

In column (4) of Table A6, we focus on pre-scheduled interviews only. Self-completed interviews without the presence of a trained interviewer may induce measurement error in the interview date. In addition, respondents may have postponed the completion of the questionnaire due to the Fukushima catastrophe. Excluding almost half of all interviews does not alter the results. In Table A5, we demonstrate the robustness of the results using three additional interview mode specifications.

The first two columns of Table A7 add (i) a linear time trend that starts after the disaster, March 11, as well as (ii) a monthly time trend that starts after the policy action, May 30, in addition to the linear time trend over the entire observation period. In column (3), we include a quadratic time polynomial in addition to the linear time trend. One concern with the identification of the policy action may be that after the sharp increase in environmental concerns, they would have decreased even without the announcement of the Nuclear Phase-Out Bill due to a decrease in media coverage and disaster-related consciousness (see Section 4.2 for further discussions). All three specifications show that the identification of the policy action is largely robust to the inclusion of split and linear time trends, as well as quadratic time polynomials in addition to year, month, and individual fixed effects.

Unbalancing the panel in column (4) of Table A7 does not affect the results either. Note that this estimation is identical to the last column in Table 1. We also checked whether environmental concerns significantly affect panel attrition over the 2 years. This is not the case; panel attrition between 2010 and 2011 accounts only for $5 \%$ of the 2010 sample.

Finally, we estimate a pure Regression Discontinuity (RD) model, using only the year 2011 and cutoff dates of 45 days around the disaster and the policy action. Table A11 in the Online Appendix shows the results. Both effects are robust to this specification.

\subsubsection{Placebo Regressions}

We employ several placebo regressions in Table A8. In column (1), we use our baseline specification but employ placebo disaster and policy action dates, March 11 and May 30, 2010. In column (2), we do the same with placebo disaster and policy action dates for 2012, March 11 and May 30, 2012. The estimates are close to zero in size and statistically insignificant. 
Columns (3) to (6) employ alternative placebo regressions using dependent variables that are arguably unrelated to the Fukushima catastrophe. To be precise, we use questions about concerns about (i) job security, (ii) health, (iii) the economy, and (iv) crime. Otherwise, the specifications are identical to our baseline specifications. All estimates are small in size and statistically insignificant.

Finally, in Table A7 of the Online Appendix, we show the results of a series of placebo regressions for 2011 using May 15, June 15, and July 15 as alternative policy action dates. All of the estimates are small in size and statistically insignificant.

\subsubsection{Medium-Run Effects}

Table 9 tests medium to long-run effects and compares the identified effects of the Fukushima disaster to those of the Chernobyl disaster using the same data set, variables, and estimation techniques.

In columns (1) and (2), we test whether environmental concerns increased significantly in the mediumrun due to the Fukushima catastrophe. For this purpose, we use the years 2009 to 2012 and estimate (unbalanced) OLS and (balanced) FE models. When estimating effects over a longer time period, we face a trade-off between considering unobservables through individual fixed effects and considering marginal populations who did not participate in the survey at least once pre- and post-Fukushima. For example, for the years 2009 to 2012, we have a total of 57,492 person-year observations, but only 7,935 individuals participated in all four waves from 2009 through 2012.

\section{[Insert Table 9 about here]}

Note that the 2012 dummy variable identifies the general change in environmental concerns in 2012 and assumes that there were no other events that could have affected concerns in 2012. The estimated 2012 effect is small in size and statistically insignificant. The same is true for the 2011 effect, which we obtain when adding up the 2011 estimate and the disaster and policy action estimates.

\subsubsection{Comparison to Long-Run Effects of the Chernobyl Disaster}

Next, we replicate our baseline specification using the Chernobyl disaster to assess its medium to longterm effects on environmental worries in the German population. This also serves as a falsification test for the identified effect of the policy action. 
Columns (3) and (4) of Table 9 basically replicate columns (1) and (2) but employ the years 1984 to 1989 and April 28, 1986, the disaster date of the Chernobyl catastrophe. ${ }^{21}$ As seen, after Chernobyl, the share of respondents who were "very concerned about environmental protection" increased by a highly significant 10 to $12 \mathrm{ppt}$. Relative to the baseline level of environmental concerns before Chernobyl, this represents an increase of about $25 \%$-almost exactly the same increase that we find after Fukushima. ${ }^{22}$ Thus, we argue that the two disasters are comparable in terms of their effects, particularly since we focus on Germany and use the same dataset, variable definitions, and estimation techniques. More importantly, the estimate for the placebo policy action in 1986 which would have occurred on July 15-exactly 81 days after the disaster when the Nuclear Phase-Out Bill was announced in 2011-is small in size and statistically insignificant. Moreover, the coefficients for 1987, 1988, and 1989 have a size of 4 to 10ppt and are highly significant. This means that-in contrast to post-Fukushima-we seem to observe a persistent jump in environmental concerns post-Chernobyl. ${ }^{23}$

In Figure A2, we nonparametrically illustrate this persistent increase in environmental concerns. ${ }^{24}$ In the visual analogue to column (3) of Table 9, it is easy to see that environmental concerns substantially increased after Chernobyl and remained at their elevated level.

\subsubsection{Replication of Richter et al. (2013)}

In a research note, Richter et al (2013) use the 2011 cross section of the SOEP to estimate the impact of Fukushima and the nuclear phaseout on life satisfaction and environmental worries in Germany. The research in this paper and in Richter et al (2013) were carried out independently and without knowing from each other. Both working papers were published in summer 2013 in the SOEPpapers Series (\#590 and \#599).

\footnotetext{
${ }^{21}$ Although the Chernobyl catastrophe happened on the evening of April 26, it took 2 days, until April 28, before the media started reporting about it.

${ }^{22}$ The baseline level of environmental concern before Chernobyl (40\%) was higher than before Fukushima (28\%).

${ }^{23}$ Also note that Metcalfe et al. (2011), who study the impact of 9/11 on mental well-being in the UK, still report a relatively large coefficient of 0.18 (which is significant at the $10 \%$ level) one year after the attacks. Since the immediate effect was 0.24 , this implicitly means that we do not observe a "return-to-the baseline" effect for $9 / 11$ in the UK.

${ }^{24}$ As in Figure 5, we report daily averages. However, since we plot the daily averages over several years and most respondents were interviewed in the first months of a year, we observe jumps in the graph. To smooth them out, we disregard days with fewer than five interviews.
} 
One major difference between this paper and Richter et al. (2013) is that this paper focuses on risk aversion and political outcomes. In addition, it estimates the well-being and voter effects for the UK and Switzerland. Moreover, as already discussed in detail in Section 2, the identification approaches differ significantly. One main difference is that this paper exploits the SOEP panel structure and nets out unobserved individual heterogeneity.

Column (1) in Tables A12 and A13 (Online Appendix) replicate the main estimation results of Richter et al. (2013) on life satisfaction on environmental worries. The next four columns then (i) cluster differently and (ii) add time trends, (iii) month fixed effects, as well as (iv) individual fixed effects along with adding the year 2010 to the estimation sample.

With regard to life satisfaction, Richter et al. (2013) find a significantly positive effect of the nuclear phaseout (but no effect of Fukushima itself). Table A12 shows that this positive nuclear phaseout effect on life satisfaction disappears when one either adds linear time trends, month fixed effects, or individual fixed effects (columns (3) to (5)).

With regard to environmental concerns, Richter et al. (2013) find a significantly positive effect of Fukushima but only a small insignificant effect of the nuclear phaseout (column (1)). Table A13 shows that one obtains our findings when one considers time trends or individual unobserved heterogeneity (columns (3) and (5)).

\section{Discussion and Conclusion}

This research shows that natural disasters can have significant effects on concerns, risk aversion, and voting preferences in presumably unaffected distant countries. Our findings show that the Fukushima disaster significantly increased environmental concerns among Germans. However, there is no empirical evidence that general well-being in the German, Swiss, or British population decreased as a result of the disaster. This finding is in line with research in the field of well-being which shows that life satisfaction measures are relatively robust to large-scale disasters and crises (Berger, 2010; Deaton, 2012; Ohtake and Yamada, 2013; Tiefenbach and Kohlbacher, 2015). Empirical checks on potential operating channels suggest that the effect on individuals' environmental concerns worked primarily through the (re-)assessment of risks of domestic reactors. After Fukushima, Germans were significantly more likely to report that they were "extremely risk averse"-in particular people who lived close to nuclear reactors-suggesting that humans adjust their risk tolerance levels after unexpected large-scale disasters. This finding is in line with recent research from China and Indonesia (Huang et al., 2013; Shah and Cameron, 2015). 
In contrast not only to the Swiss reaction to Fukushima, but also the German reaction to the Chernobyl disaster in 1986, Germans' environmental concerns decreased again after the hitherto pro-nuclear governing center-right coalition made a drastic and sharp turnaround in its energy policy. On May 30, 2011, Angela Merkel announced that a new bill would permanently shut down the eight oldest reactors and implement the staggered phaseout of the remaining ones. The bill was combined with a large-scale government program supporting the transition to renewables. We find that the reduction in environmental concerns was particularly strong among individuals who lived in close proximity to the eight oldest reactors, supporters of the Green party, and women.

Finally, we show that the disaster increased political support for the Green party in Germany, Switzerland, and the UK. It has always been one of the Green party's main objectives to phase out of nuclear energy. While the increase in voter sympathies was universal in Germany, in Switzerland and the UK, it was concentrated among people who live in close distance to nuclear reactors. For Germany, we also find that the intensity of political party support increased significantly, while there is no evidence that the disaster triggered more political interest at the extensive margin.

Complementary evidence shows that Germans are actually willing to pay for nuclear-free energy production, most likely in return for a lower level of environmental concerns. In representative polls, $70 \%$ claim that they would be willing to pay higher energy prices in return for the transition to renewables (Infratest Dimap, 2011b). Part of the Energiewende is a fixed subsidy for every kilowatt hour (kWh) produced by renewables. The $€ 18 \mathrm{bn}$ annual cost of this policy is paid by consumers through a tax on electricty. ${ }^{25}$ In 2013 , this tax amounted to 5.3 Eurocent per kWh (Bundesregierung, 2013). Since the average household consumes about 3,500 kWh per year, it effectively pays $€ 185$ or $€ 15$ per month for the transition to renewables (EnergieAgentur NRW, 2012). While this represents a federal mandatory tax, a study by Check24 (2012) finds that, before Fukushima, 37\% of all consumers who switched their energy provider chose electricity from renewables. Immediately after Fukushima, this share doubled to $74 \%$ and was still $64 \% 1$ year after the disaster.

An obvious question is whether the results of this study carry over to other (non-European) countries. Complementary evidence for Switzerland and the UK is consistent with the German experience, but the effects are less pronounced. The German example suggests that nuclear catastrophes do not only have local negative effects but also significant spillover effects on other countries. In addition to concerns, we

\footnotetext{
${ }^{25}$ Meanwhile, the Energiewende is exemplary with at least 65 countries-among them the USA-copying the subsidy (called "Einspeisevergütung") for renewables (REN21, 2013).
} 
demonstrate a shift to the right tail of the risk aversion distribution. How changes in concerns and risk tolerance translate into changes in actual economic behavior is a field for future research. The German experience teaches us that it can result in a rarely observed abrupt shift in long-term policies: a complete phaseout of nuclear energy. 


\section{Acknowledgements:}

The authors thank the anonymous reviewers, the editor Erdal Tekin, Silke Anger, Peter Eibich, Ronny Freier, Jan Marcus, Jürgen Schupp, Gert G. Wagner, Michael Weinhardt, and participants at the European Economic Association Annual Meeting 2014, Toulouse, the International Association for Applied Econometrics Annual Meeting 2014, London, the European Society for Population Economics Annual Meeting 2014, Braga, the European Public Choice Society Annual Meeting 2014, Cambridge, and the "Public Finances and Living Conditions" Cluster Seminar at DIW Berlin. A special thank goes to Adam Lederer and Eric Maroney for an excellent editing of this paper and to Aline Passlack for an excellent research assistance. The authors take responsibility for all remaining errors in and shortcomings of this article. 


\section{Literature}

Acemoglu D, Mikhail G, Tsyvinski A (2011) Power fluctuations and political economy. J Econ Theory 146(3):1009-1041

Aklin M, Bayer P, Harish SP, Urpelainen J (2013) Understanding environmental policy preferences: new evidence from Brazil. Ecol Econ 94(C):28-36

Almond D, Edlund L, Palme M (2009) Chernobyl's subclinical legacy: prenatal exposure to radioactive fallout and school outcomes in Sweden. Q J Econ 124(4):1729-1772

Anderson K, Rausser G, Swinnen J (2013) Political economy of public policies: insights from distortions to agricultural and food markets. J Econ Lit 51(2):423-477

Aoki M, Rothwell G (2013) A comparative institutional analysis of the Fukushima nuclear disaster: lessons and policy implications. Energy Policy 53(C):240-247

Askitas N, Zimmermann KF (2009) Google econometrics and unemployment forecasting. Appl Econ Q 55 (2):107-120

Bauer TK, Braun S, Kvasnicka M (2013) Distant event, local effects? Fukushima and the German housing market. Ruhr Economic Papers 0433

Benjamin DJ, Heffetz O, Kimball MS, Szembrot N (2014a) Beyond happiness and satisfaction: toward well-being indices based on stated preference. Am Econ Rev 104(9):2698-2735

Benjamin DJ, Heffetz O, Kimball MS, Rees-Jones A (2014b) Can marginal rates of substitution be inferred from happiness data? evidence from residency choices. Am Econ Rev 104(11):3498-3528

Berger EM (2010) The Chernobyl disaster, concern about the environment, and life satisfaction. Kyklos 63(1):1-8

Bertrand M, Duflo E, Mullainathan S (2004) How much should we trust differences-in-differences estimates? Q J Econ 119(1):249-275

Bond TN, Lang K (2014) The sad truth about happiness scales. NBER Working Papers 19950

Budowski M, Tillmann R, Zimmermann E, Wernli B, Scherpenzeel A, Gabadinho A (2001) The Swiss Household Panel 1999-2003: data for research on micro-social change. ZUMA Nachr 25(49): 100-125. http://nbnresolving.de/urn:nbn:de:0168-ssoar-211073

Buesseler KO, Jayne SR, Fisher NS, Rypina II, Baumann H, Baumann Z, Breier CF, Douglass EM, George J, Macdonald AM, Miyamoto H, Nishikawa J, Pike SM, Yoshida S (2012) Fukushima- derived radionuclides in the ocean and biota off Japan. Proc Natl Acad Sci 109(16):5984-5988

Bundesregierung (2011a) Regierungserklärung von Bundeskanzlerin Angela Merkel ("State of the Union Address of Chancellor Angela Merkel“), June 9, 2011: http://www.youtube.com/watch?v=jFm1I_1Q3Ug, http://www.bundesregierung.de/ContentArchiv/DE/Archiv17/Regierungserklaerung/2011/2011-06-09-merkelenergie-zukunft.html, last accessed on July 2, 2013

Bundesregierung (2011b) Bundesregierung setzt Laufzeitverlängerung für drei Monate aus: http://www.bundesregierung.de/Content/DE/Artikel/2011/03/2011-03-14-moratorium-kernkraft-deutschland.html, last accessed on July 2, 2013

$\begin{array}{lllll}\text { Bundesregierung } & \text { (2011c) } & \text { Regierungspressekonferenz } & \text { vom } & 1 .\end{array}$ http://www.bundesregierung.de/Content/DE/Mitschrift/Pressekonferenzen/2011/05/2011-06-01-regpk.htmlx, last accessed on July 2, 2013

Bundesregierung (2011d) Bundespräsident unterschreibt Änderung des Atomgesetzes: http://www.bundesregierung.de/Content/DE/Artikel/2011/06/2011-06-06-Schrittweiser\%20-Atomausstieg.html, last accessed on July 2, 2013

Bundesregierung (2011e) Pressekonferenz zum Energiekonzept der Bundesregierung mit Bundeskanzlerin Merkel, BM Rösler, BM Röttgen und BM Ramsauer: http://www.bundesregierung.de/Content/DE/Mitschrift/Pressekonferenzen/2011/05/2011-05-30-pk-bk-bmenergiekonzept.html, last accessed on July 2, 2013 
Bundesregierung (2013) Energiekonzept, http://www.bundesregierung.de/Content/DE/Artikel/2013/07/2013-07-08reform-der-photovoltaik-foerderungerfolgreich.html, last accessed on July 10, 2013

Büscher B (2009) Connecting political economies of energy in South Africa. Energy Policy 37(10):3951-3958

Cassar A, Healy A, von Kessler C (2011) Trust, risk and time preferences after a natural disaster: experimental evidence from Thailand. University of San Francisco Working Paper

Cesur R, Ulker A, Tekin E (2013) Air pollution and infant mortality: evidence from the penetration of natural gas. NBER Working Paper No. 18736

Cesur R, Chesney A, Sabia JJ (2014) The effect of combat exposure on risky health behaviors: new evidence from the global. Mimeo

Cesur R, Sabia JJ, Tekin E (2015) Combat exposure and migraine headache: evidence from exogenous deployment assignment. Econ Hum Biol 16:81-99

Check24 (2012) Ein Jahr nach Fukushima: 64 Prozent der Stromwechsler wählten im Februar 2012 Ökostrom-Tarif. http://www.check24.de, last accessed on July 10, 2013

Clark AE, Senik C (2010) Who compares to whom? The anatomy of income comparisons in Europe. Econ J 120(544):573-594

Clark AE, Kristensen N, Westergård-Nielsen N (2009) Job satisfaction and co-worker wages: status or signal? Econ J 119(536):430-447

Cohn A, Engelmann J, Fehr E, Maréchal MA (2015) Evidence for countercyclical risk aversion: an experiment with financial professionals. American Economic Review, 105(2):860-885

Csereklyei Z (2013) Measuring the impacts of nuclear accidents on energy policy. Department of Economics Working Paper Series 151. WU Vienna University of Economics and Business, Vienna

Cullen J (2013) Measuring the environmental benefits of wind-generated electricity. Am Econ J: Econ Policy 5(4):107133

Czap NV, Czap HJ (2010) An experimental investigation of revealed environmental concern. Ecol Econ 69(10):20332041

D'Amuri F, Marcucci JM (2012) The predictive power of Google searches in forecasting unemployment. Economic working papers 891, Bank of Italy

Danzer AM, Danzer N (2011) The long-term effects of the Chernobyl catastrophe on subjective well-being and mental health. IZA Discussion Papers 5906

Deaton A (2012) The financial crisis and the well-being of Americans. Oxf Econ Pap 64(1):1-26

Dohmen T, Falk A, Huffman D, Sunde U, Schupp J, Wagner GG (2011) Individual risk attitudes: measurement, determinants, and behavioral consequences. J Eur Econ Assoc 9(3):522-550

Draca M, Machin S, Witt R (2011) Panic on the streets of London: police, crime, and the July 2005 terror attacks. Am Econ Rev 101(5):2157-2181

Eckel CC, El-Gamal MA, Wilson RK (2009) Risk loving after the storm: a Bayesian-network study of Hurricane Katrina evacuees. J of Econ Behav \& Organ, 69(2): 110-124

EnergieAgentur NRW (2012) Erhebung „Wo im Haushalt bleibt der Strom? Anteile, Verbrauchswerte und Kosten von 12 Verbrauchsbereichen in $1-$ bis 6-Personen-Haushalten, http://www.energieagentur.nrw.de/_database/_data/datainfopool/erhebung_wo_bleibt_der_strom.pdf, last accessed on July 10, 2013

Frijters P, Haisken-DeNew JP, Shields MA (2004) Money does matter! Evidence from increasing real income and life satisfaction in East Germany following reunification. Am Econ Rev 94(3):730-740

Glaser A (2011) After Fukushima: preparing for a more uncertain future of nuclear power. Electr J 24 (6):27-35

Greenstone M, Gayer T (2009) Quasi-experimental and experimental approaches to environmental economics. J Environ Econ Manag 57(1):21-44 
Halla M, Zweimüller M (2014) Parental response to early human capital shocks: evidence from the Chernobyl accident, Economics working papers 2014-02. Department of Economics, Johannes Kepler University Linz, Austria

Hanaoka C, Shigeoka H, Watanabe Y (2014) Do risk preferences change? Evidence from panel data before and after the Great East Japan earthquake. https://sites.google.com/site/hshigeoka, last accessed May 9, 2014

Hippel FN (2011) The radiological and psychological consequences of the Fukushima Daiichi accident. Bull At Sci $67(5): 27$

Hommerich C (2012) Trust and subjective well-being after the Great East Japan earthquake, tsunami and nuclear meltdown: preliminary results. Int J Jpn Sociol 21(1):46-64

Huang L, Zhou Y, Han Y, Hammitt JK, Bi J, Liu Y (2013) Effect of the Fukushima nuclear accident on the risk perception of residents near a nuclear power plant in China. Proc Natl Acad Sci 110(49):19742-19747

Huenteler J, Schmidt TS, Kanie N (2012) Japan's post-Fukushima challenge-implications from the German experience on renewable energy policy. Energy Policy 45(C):6-11

Imbens GW, Wooldridge JM (2009) Recent developments in the econometrics of program evaluation. J Econ Lit 47(1):5-86

Infratest Dimap (2009) Bundesweite Umfragen, July 2019, http://www.infratest-dimap.de/umfragenanalysen/bundesweit/umfragen/aktuell/eher-geringesvertrauen-in-sicherheit-von-akws-unterstuetzung-desumlagefinanzierten-rentensystems, last accessed on July 27, 2013

Infratest Dimap (2010) Bundesweite Umfragen, August 2010, http://www.infratest-dimap.de/umfragenanalysen/bundesweit/arddeutschlandtrend/2010/august/, last accessed on July 2, 2013

Infratest Dimap (2011a) Bundesweite Umfragen, Deutschlandtrend Juni 2011. http://www.infratestdimap.de/umfragen-analysen/bundesweit/arddeutschlandtrend/2011/juni/, last accessed on July 2, 2013

Infratest Dimap (2011b) Bundesweite Umfragen, ARD DeutschlandTREND, März 2011 extra: Atom Katastrophe in Japan: http://www.infratestdimap.de/umfragen-analysen/bundesweit/ard-deutschlandtrend/2011/maerz-extra/, last accessed on July 2, 2013

Infratest Dimap (2011c) Bundesweite Umfragen, March 15-16, 2011. http://www.infratest-dimap.de/umfragenanalysen/bundesweit/umfragen/aktuell/aussetzung-der-laufzeitverlaengerung-gilt-nicht-als-glaubwuerdigerkurswechsel/, last accessed on July 2, 2013

Institute of Nuclear Power Operations (INPO) (2011) Special report on the nuclear accident at the Fukushima Daiichi nuclear power station. http://www.nei.org/, last accessed May 27, 2013

Kassenboehmer SC, Haisken-DeNew JP (2009) You're Fired! You're fired! The causal negative effect of entry unemployment on life satisfaction. Econ J 119(536):448-462

Kawashima S, Takeda F (2012) The effect of the Fukushima nuclear accident on stock prices of electric power utilities in Japan. Energy Econ 34(6):2029-2038

Knabe A, Rätzel S, Schöb R, Weimann J (2010) Dissatisfied with life but having a good day: time-use and well-being of the unemployed. Econ J 120(547):867-889

Lehmann, H, Wadsworth, J (2011) The impact of Chernobyl on health and labour market performance. J of Health Econ 5:843-857

Luechinger S (2009) Valuing air quality using the life satisfaction approach. Econ J 119(536):482-515

Luechinger S, Raschky PA (2009) Valuing flood disasters using the life satisfaction approach. J Public Econ 93(3-4):620633

Luechinger S, Meier S, Stutzer A (2010) Why does unemployment hurt the employed? Evidence from the life satisfaction gap between the public and the private sector. J Hum Resour 45(4):998-1045

Lusk JL, Coble, KH (2008) Risk aversion in the presence of background risk: evidence from an economic experiment, in: James C. Cox, Glenn W. Harrison (ed.) Risk aversion in experiments. Research in Experimental Economics, Volume 12, Emerald Group Publishing Limited:315-340 
Marcus J (2013) The effect of unemployment on the mental health of spouses-evidence from plant closures in Germany. J Health Econ 32(3):546-558

Malmendier U, Nagel S (2011) Depression babies: do macroeconomic experiences affect risk taking? Q J of Econ, 126(1):373-416

Marron DB, Toder EJ (2014) Tax policy issues in designing a carbon tax. Am Econ Rev 104(5):563-568

Metcalfe R, Powdthavee N, Dolan P (2011) Destruction and distress: using a quasi-experiment to show the effects of the September 11 attacks on mental well-being in the United Kingdom. Econ J 121(550):F81-F103

Murray BC, Cropper ML, de la Chesnaye FC, Reilly JM (2014) How effective are US renewable energy subsidies in cutting greenhouse gases? Am Econ Rev 104(5):569-574

Ockwell DG (2008) Energy and economic growth: grounding our understanding in physical reality. Energy Policy 36(12):4600-4604

Ohtake F, Yamada K (2013) Appraising the unhappiness due to the Great East Japan earthquake: evidence from weekly panel data on subjective well-being. ISER Discussion Paper No. 876

Oswald AJ (1997) Happiness and economic performance. Econ J 107(445):1815-1831

Oswald AJ, Wu S (2011) Well-being across America. Rev Econ Stat 93(4):1118-1134

Owen AL, Conover E, Videras J, Wu S (2012) Heat waves, droughts, and preferences for environmental policy. J Policy Anal Manag 31(3):556-577

Pesko MF (2014a) Hurrican Katrina: behavioral health and health insurance in non-impacted vulnerable counties. Mimeo https://sites.google.com/site/mikepesko/ongoing-research, last accessed on May 9, 2014

Pesko MF (2014b) Stress and smoking: associations with terrorism and causal impact. Contemp Econ Policy 32(2):351371

Pesko MF, Baum CF (2014) The self-medication hypothesis: evidence from terrorism and cigarette accessability. Mimeo. https://sites.google.com/site/mikepesko/ongoing-research, last accessed on May 9, 2014

Pindyck RS (2013) Climate change policy: what do the models tell us? J Econ Lit 51(3):860-872

Reaktorsicherheitskommission (2011) Anlagenspezifische Sicherheitsüberprüfung (RSK-SÜ) deutscher Kernkraftwerke unter Berücksichtigung der Ereignisse in Fukushima-I (Japan): http://www.rskonline.de, last accessed on July 2, 2013

Rehdanz K, Welsch H, Narita D, Okubo T (2013) Well-being effects of a major negative externality: the case of Fukushima, Kiel Working Papers 1855

REN21: Renewable Energy Policy Network for the 21st Century (2013) Renewables 2013: Global Status Report, http://www.ren21.net/REN21Activities/GlobalStatusReport.aspx, last accessed on July 10, 2013

Richter F, Steenbeck M, Wilhelm M (2013) Nuclear accidents and policy: notes on public perception. SOEPpapers on Multidisciplinary Panel Data Research 590

Rieu A-M (2013) Thinking after Fukushima. Epistemic shift in social sciences. Asia Europe Journal 11(1):65-78

Schüller S (2012) The effects of 9/11 on attitudes toward Immigration immigration and the moderating role of education. IZA Discussion Papers 7052

Senik C (2009) Direct evidence on income comparisons and their welfare effects. J Econ Behav Organ 72 (1):408-424

Shah M, Cameron L (2015) Risk-taking behavior in the wake of natural disasters. J of Human Res, forthcoming

Sjöberg L (1998) Worry and risk perception. Risk Anal 18(1):85-93

Slovic P (1987) Perception of risk. Science 236(4799):280-285

Socio-Economic Panel (SOEP) (2012) Data for years 1984-2012, version 29, SOEP. doi: 10.5684/soep.v29

Strielkowski W, Krška Š, Lisin E (2013) Energy economics and policy of renewable energy sources in the European Union. Int J Energy Econ Policy 3(4):333-340 
Tagesschau (2011) "Wahl Baden-Würtemberg: Analyse Wählerwanderung," http://wahl.tagesschau.de/wahlen/201103-27-LT-DE-BW/analyse-wanderung.shtml, last accessed on May 31, 2015.

Tatic K, Cinjarevic M (2010) Relationship between environmental concern and green purchasing behavior. Interdisciplinary Manag Res 6:801-810

Thomas S (2012) What will the Fukushima disaster change? Energy Policy 45(C):12-17

Tiefenbach T, Kohlbacher F (2013) Disentangling the happiness effects of natural disasters: the mediating role of prosocial behavior. German Institute for Japanese Studies, Working Paper 13/5

Tiefenbach T, Kohlbacher F (2015) Happiness in Japan in times of upheaval: empirical evidence from the national survey on lifestyle preferences. J Happiness Stud 16(2):333-366

Uchida Y, Takahashi Y, Kawahara K (2014) Changes in hedonic and eudaimonic well-being after a severe nationwide disaster: the case of the Great East Japan earthquake. J Happiness Stud 15(1):207-221

University of Essex. Institute for Social and Economic Research and National Centre for Social Research, Understanding Society: Waves 1-2, 2009-2011. 4th ed. Colchester, Essex: UK Data Archive [distributor], December 2012. SN: 6614

Urban J, Ščasný M (2012) Exploring domestic energy-saving: the role of environmental concern and background variables. Energy Policy 47(C):69-80

Vieider FM, Lefebvre M, Bouchouicha R, Chmura T, Hakimov R, Krawczyk M, Martinsson P (2015) Common components of risk and uncertainty attitudes across contexts and domains: evidence from 30 countries. J of the $E$ E $A$ $13(3): 421-452$

Vivoda V (2012) Japan's energy security predicament post-Fukushima. Energy Policy 46(C):135-143

Wagner GG, Frick JR, Schupp J (2007) The German socio-economic panel study (SOEP) evolution, scope and enhancements. Schmollers Jahrbuch J Appl Soc Sci Stud 127(1):139-169

Wang Q, Xi C, Xu Y-C (2013) Accident like the Fukushima unlikely in a country with effective nuclear regulation: literature review and proposed guidelines. Renew Sust Energ Rev 17(C):126-146

Wangler $L$ (2012) The political economy of the green technology sector: a study about institutions, diffusion and efficiency. Eur J Law Econ 33(1):51-81

Welsch H, Biermann P (2014) Fukushima and the preference for nuclear power in Europe: evidence from subjective well-being data. Ecol Econ 108:171-179

WHO (2013) Health Risk Assessment from the Nuclear Accident after the 2011 Great East Japan Earthquake and Tsunami, Based on a Preliminary Dose Estimation, Report http://www.who.int/ionizing_radiation/pub_meet/fukushima_risk_assessment_2013/en/index.html, last accessed on May 17, 2013

Winkelmann L, Winkelmann R (1998) Why are the unemployed so unhappy? Evidence panel data. Economica 65(257):1-15

World Nuclear Association (2015) Nuclear Power in Japan: Public Opinion http://www.worldnuclear.org/info/Country-Profiles/Countries-G-N/Japan/, last accessed on March 18, 2015

Yamamura E (2012) Experience of technological and natural disasters and their impact on the perceived risk of nuclear accidents after the Fukushima nuclear disaster in Japan 2011: A cross-country analysis. J Socio-Econ 41(4):360-363

Ziebarth NR, Schmitt M, Karlsson M (2014) The short-term population health effects of weather and pollution. http://www.human.cornell.edu/pam/people/nicolas_ziebarth.cfm, last accessed on July 26, 2014 


\section{Figures and Tables}

Figure 1: Timeline of Policy Action Following Fukushima

\section{March 14, 201}

Temporary Shutdown of

7 Oldest Nuclear Power Plantsa)

+ Security Assessment of all Plants

+ Ethics Commssion on Nuclear Energy

May 30, 2011

Permanent Shutdown of

8 Oldest Nuclear Power Plants

Peversal of Lifetime

+ Transition to Renewable Energy

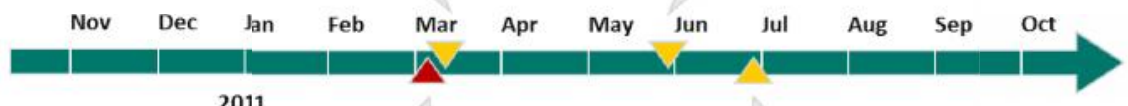

2011

March 11, 2011

June 30, 2011

Meltdown at

Fukushima-Daiichi Nuclear Power Plant

Passage of

Second Nuclear Phase-Out Bill

Figure 2: Nuclear Power Plants and Waste Sites in Germany

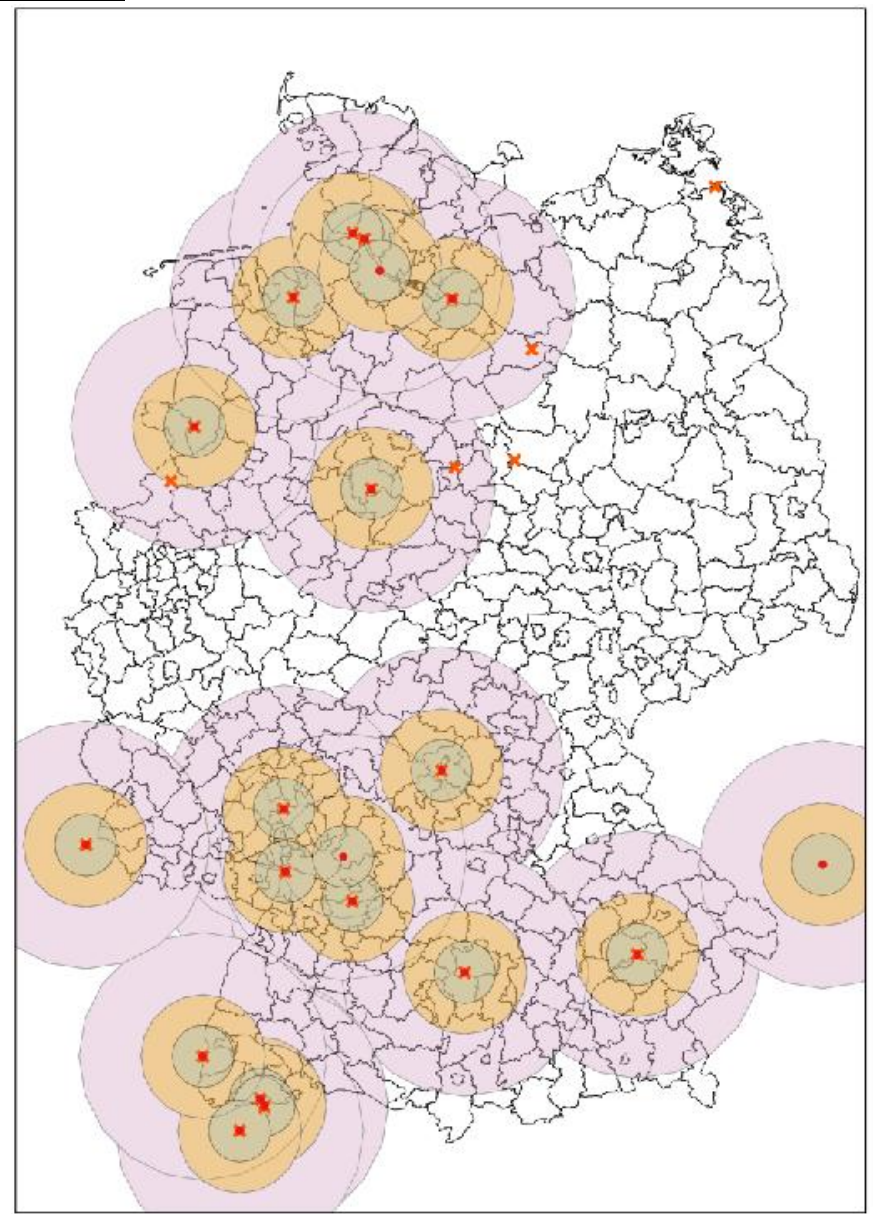

Notes: Circles indicate 25, 50, and $100 \mathrm{~km}$ radii. Dots indicate nuclear power plants; crosses indicate (temporary) nuclear waste sites. 
Figure 3: "Renewable Energy" Google Trend Search for Germany, Feb to July 2011
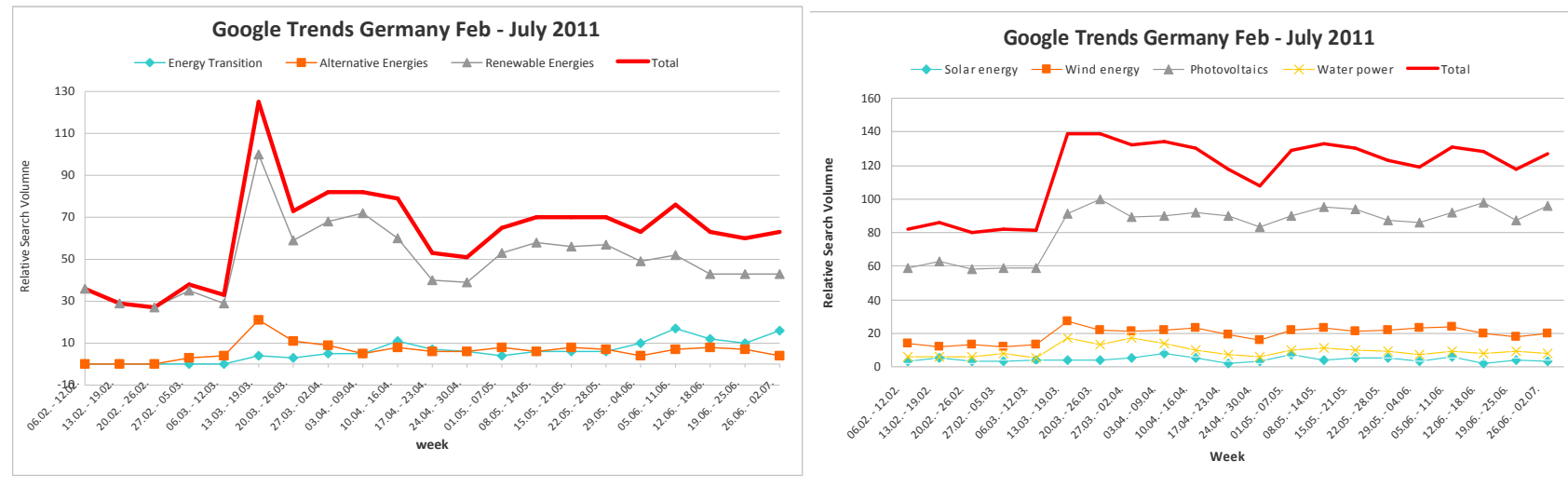

Figure 4: Newspaper Articles on Fukushima vs. Chernobyl in Weeks before and After Disaster

Keyword Search Frankfurter Allgemeine Zeitung (FAZ):

Fukushima vs. Chernobyl (normalized)

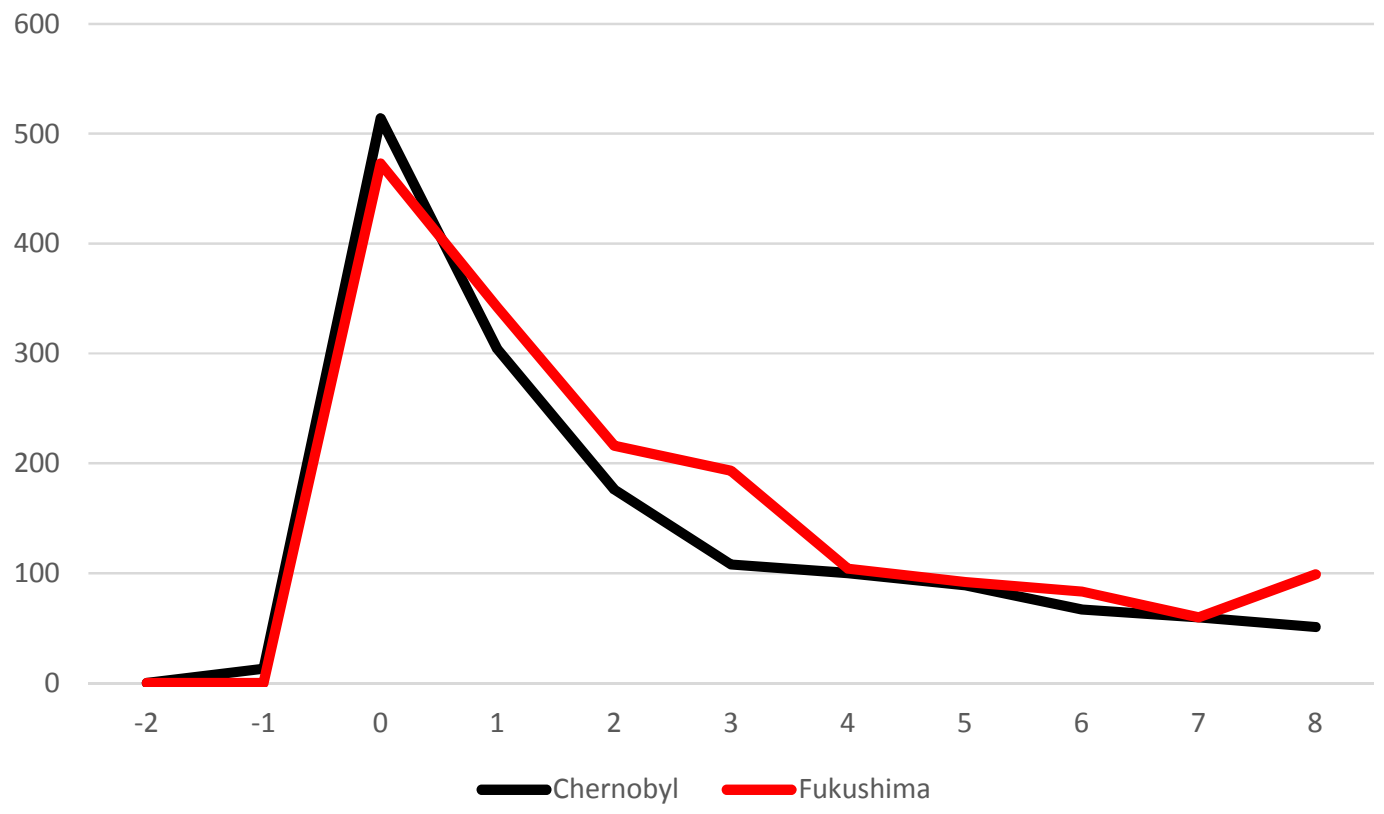


Figure 5: Change in Concerns about Environmental Protection Very Concerned About Environmental Protection

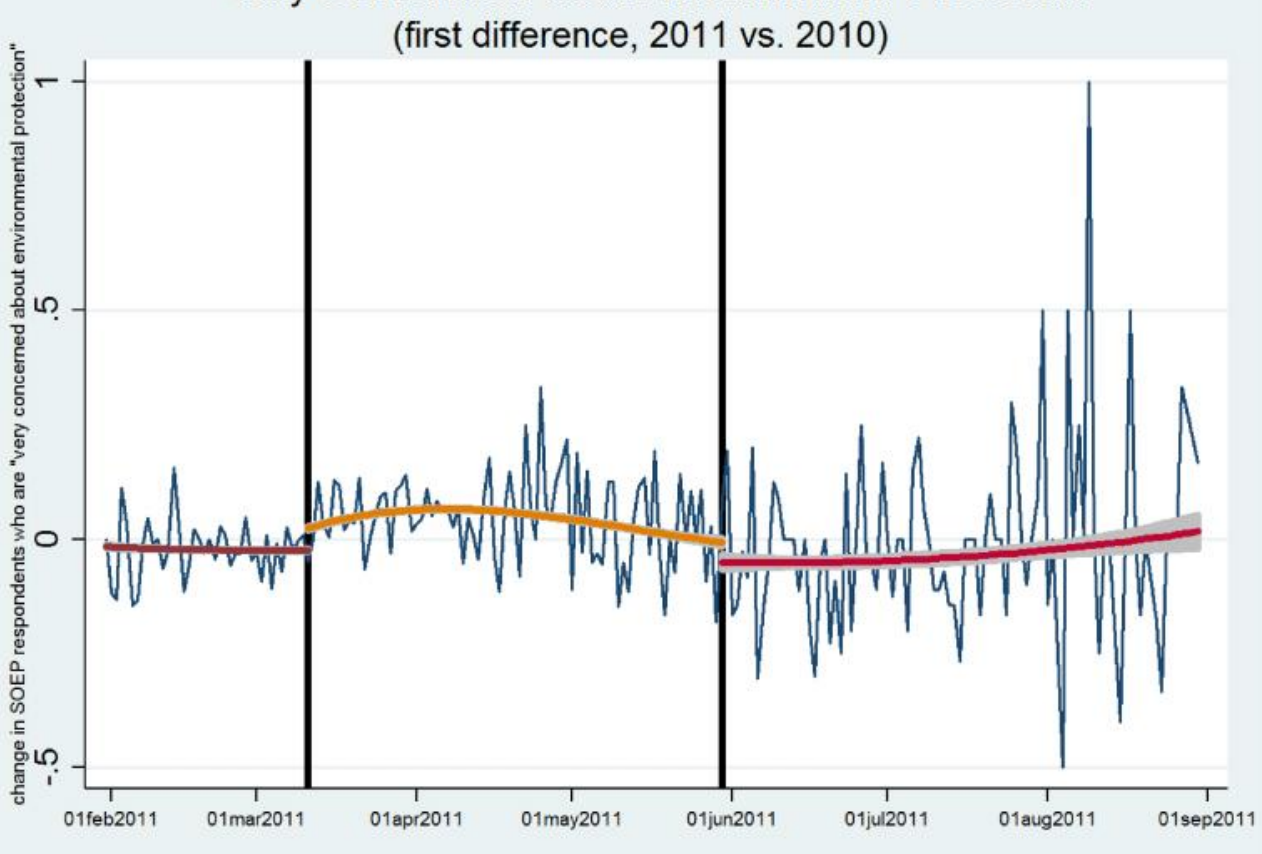

Figure 6: Change in Life Satisfaction

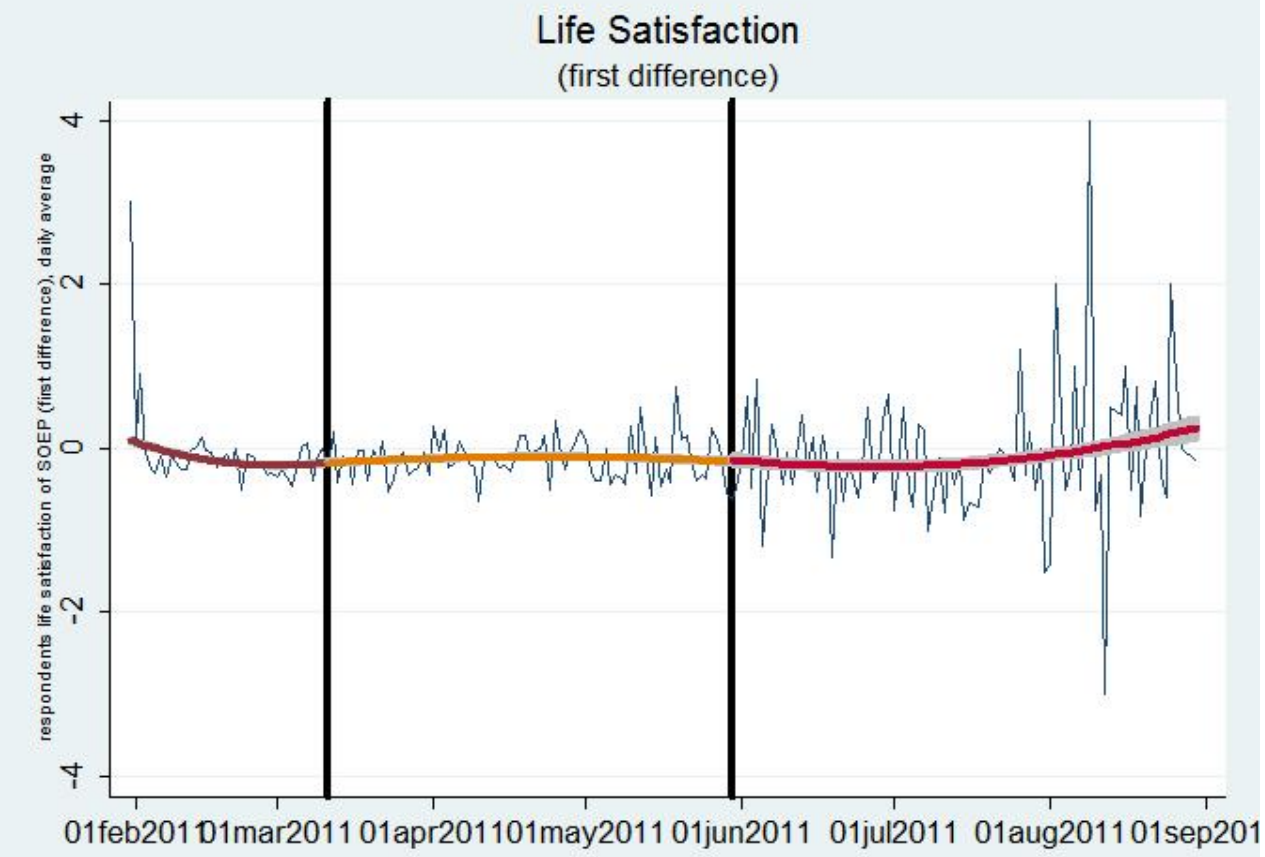


Figure 7: Nuclear Power Plants and Respondents' Residency (SHP) in Switzerland

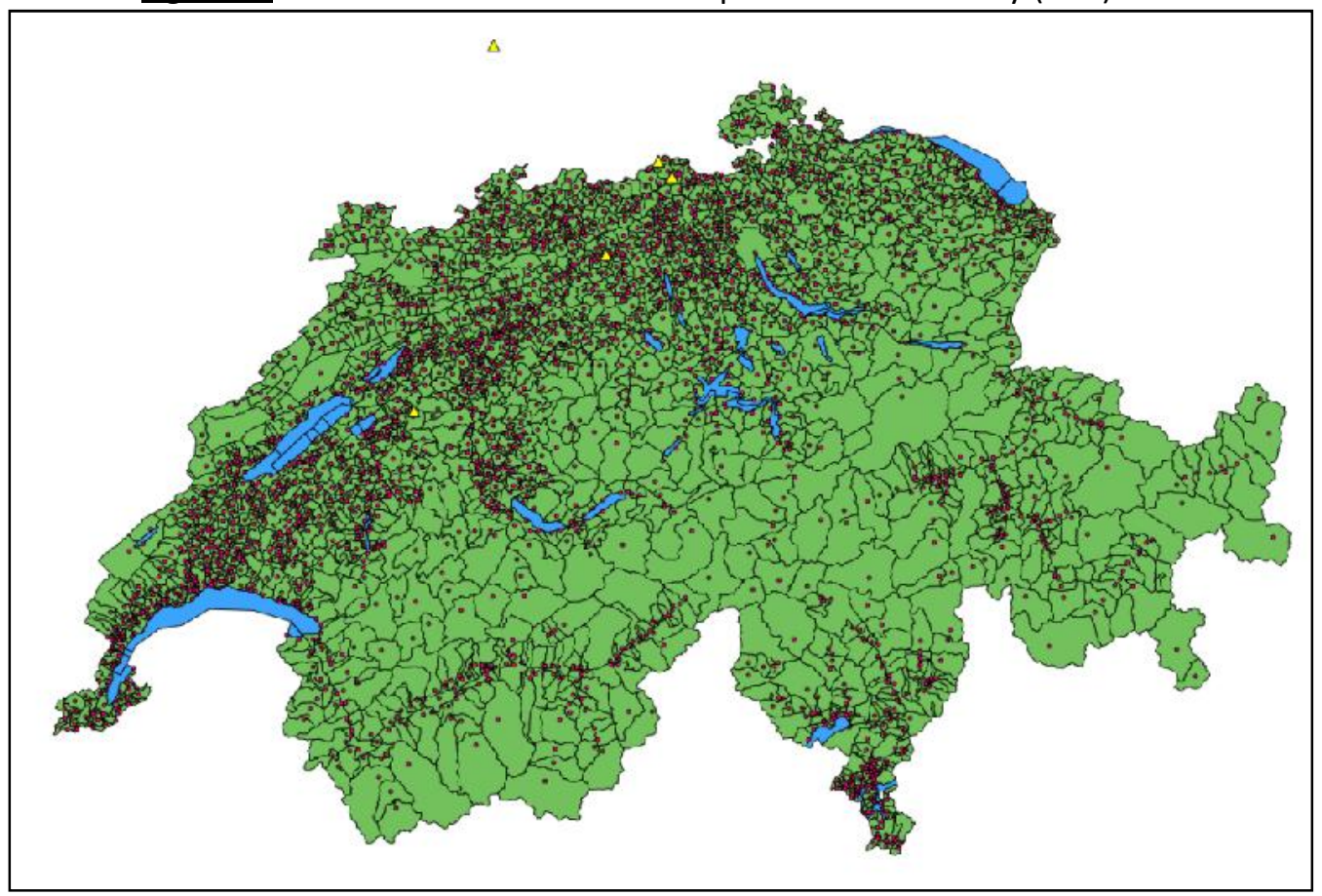

Note: Swiss municipalities are in green; the centroids are in red and nuclear power plants represented by yellow triangles.

Figure 8: Nuclear Power Plants and Respondents' Residency (Understanding Society) in the UK

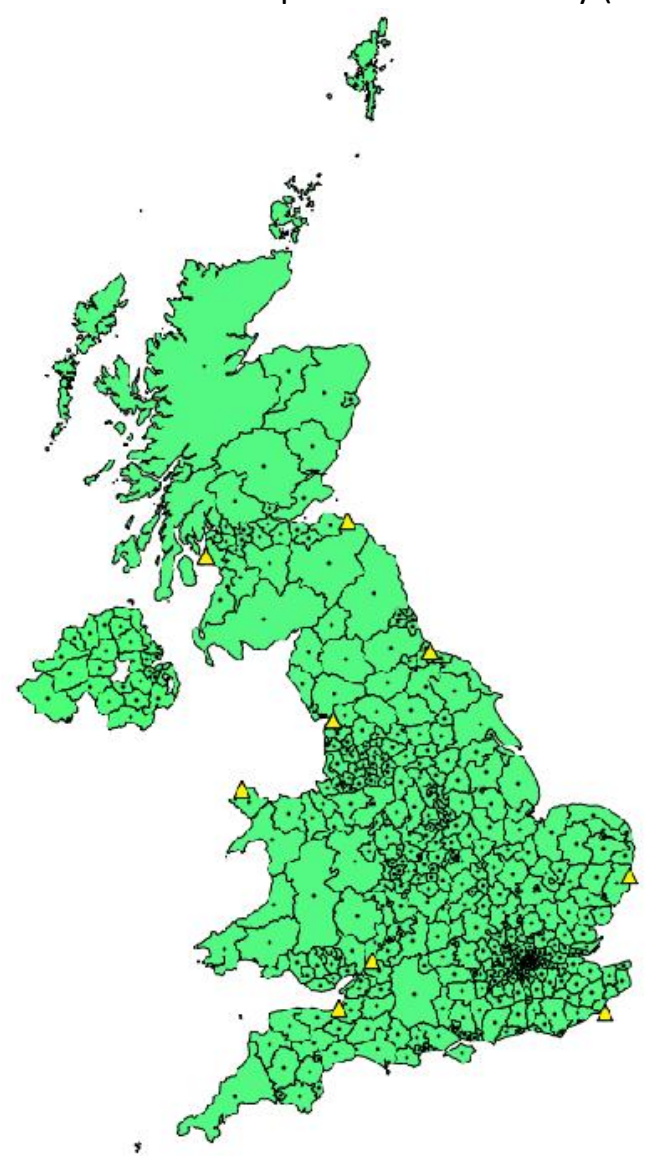

Note: Note: Great Britain Local Authority Districts and Northern Ireland District Council Areas are in green; the centroids are in black and nuclear power plants represented by yellow triangles. 
Table 1: Effects of the Meltdown and the Permanent Shutdown on Environmental Concerns in Germany

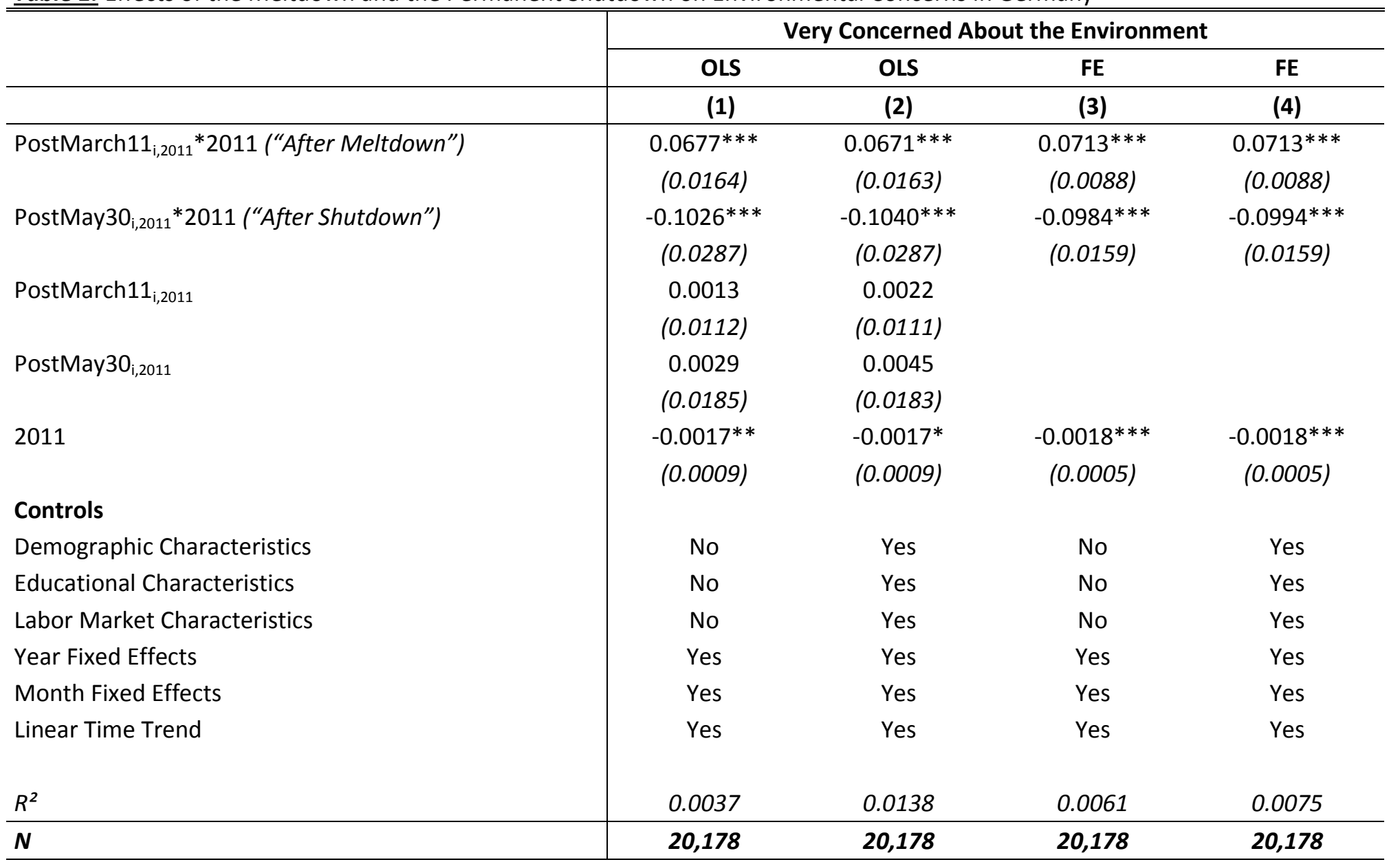

Note: ${ }^{*} p<0.1, * * p<0.05, * * * p<0.01$; standard errors are in parentheses and clustered at the interview date level. Treatment status is defined by the time-invariant dummy variables PostMarch $11_{i, 2011}$ and PostMay $30_{i, 2011}$, which drop out in the FE models. The dependent variable is a dummy which equals one if the individual is very concerned about the environment. Each column stands for one model similar to Equation (1). Source: SOEP v29, 2010-2011, balanced panel, own calculations. 
Table 2: Effects on Alternative Well-Being Measures in Germany

\begin{tabular}{|c|c|c|c|c|}
\hline & Life Satisfaction & Happiness & Sadness & $\begin{array}{l}\text { Very Concerned About } \\
\text { Climate Change }\end{array}$ \\
\hline & (1) & (2) & (3) & (4) \\
\hline \multirow[t]{2}{*}{ PostMarch11 ${ }_{\mathrm{i}, 2011}{ }^{*} 2011$ ("After Meltdown") } & 0.0344 & 0.0047 & $0.0453^{* * *}$ & $0.0575^{* * *}$ \\
\hline & (0.0318) & $(0.0075)$ & (0.0102) & (0.0072) \\
\hline \multirow[t]{2}{*}{ PostMay30 ${ }_{\mathrm{i}, 2011}{ }^{*} 2011$ ("After Shutdown") } & -0.0455 & -0.0158 & -0.0374 & $-0.0551 * * *$ \\
\hline & (0.0526) & (0.0188) & $(0.0264)$ & (0.0141) \\
\hline
\end{tabular}

\section{Controls}

Demographic Characteristics

Educational Characteristics

Labor Market Characteristics

Individual Fixed Effects

Year Fixed Effects

Month Fixed Effects

Linear Time Trend

$\begin{array}{cccc}\text { Yes } & \text { Yes } & \text { Yes } & \text { Yes } \\ \text { Yes } & \text { Yes } & \text { Yes } & \text { Yes } \\ \text { Yes } & \text { Yes } & \text { Yes } & \text { Yes } \\ \text { Yes } & \text { Yes } & \text { Yes } & \text { Yes } \\ \text { Yes } & \text { Yes } & \text { Yes } & \text { Yes } \\ \text { Yes } & \text { Yes } & \text { Yes } & \text { Yes } \\ \text { Yes } & \text { Yes } & \text { Yes } & \text { Yes }\end{array}$

$R^{2}$

Note: $* p<0.1, * * p<0.05, * * * p<0.01 ;$ standard errors are in parentheses and clustered at the interview date level. Treatment status is defined by the time-invariant dummy variables PostMarch11 $1_{i, 2011}$ and PostMay30 ${ }_{i, 2011}$. Happiness and sadness measures refer to the four weeks prior to the interview (see Section 3). April 11, 2011, and June 30, 2011, are the cut-off dates for these models. Each column stands for one FE model similar to Equation (1), except for Column (1), which is an ordered probit model.

Source: SOEP v29, 2010-2011, balanced panel, own calculations. 
Table 3: Effects on Risk Aversion in Germany

\begin{tabular}{|c|c|c|c|c|}
\hline & Risk Averse & $\begin{array}{l}\text { Moderately } \\
\text { Risk Averse }\end{array}$ & $\begin{array}{c}\text { Very } \\
\text { Risk Averse }\end{array}$ & $\begin{array}{c}\text { Extremely } \\
\text { Risk Averse }\end{array}$ \\
\hline & (1) & (2) & (3) & (4) \\
\hline \multirow[t]{2}{*}{ PostMarch11 ${ }_{\mathrm{i}, 2011}{ }^{*} 2011$ ("After Meltdown") } & -0.0013 & -0.0048 & $0.0163 * * *$ & $0.0200 * * *$ \\
\hline & $(0.0095)$ & (0.0079) & $(0.0060)$ & $(0.0041)$ \\
\hline \multirow[t]{2}{*}{ PostMay30 ${ }_{i, 2011}{ }^{*} 2011$ (“After Shutdown") } & -0.0100 & -0.0100 & 0.0021 & $-0.0273 * * *$ \\
\hline & $(0.0163)$ & $(0.0123)$ & $(0.0104)$ & $(0.0080)$ \\
\hline
\end{tabular}

\section{Controls}

Demographic Characteristics

Educational Characteristics

Labor Market Characteristics

Individual Fixed Effects

Year Fixed Effects

Month Fixed Effects

Linear Time Trend

$R^{2}$

$N$

$\begin{array}{llll}\text { Yes } & \text { Yes } & \text { Yes } & \text { Yes } \\ \text { Yes } & \text { Yes } & \text { Yes } & \text { Yes } \\ \text { Yes } & \text { Yes } & \text { Yes } & \text { Yes } \\ \text { Yes } & \text { Yes } & \text { Yes } & \text { Yes } \\ \text { Yes } & \text { Yes } & \text { Yes } & \text { Yes } \\ \text { Yes } & \text { Yes } & \text { Yes } & \text { Yes } \\ \text { Yes } & \text { Yes } & \text { Yes } & \text { Yes } \\ & & & \\ 0.0129 & 0.0091 & 0.0085 & 0.0064 \\ \mathbf{2 0 , 1 7 8} & \mathbf{2 0 , 1 7 8} & \mathbf{2 0 , 1 7 8} & \mathbf{2 0 , 1 7 8}\end{array}$

Note: $* p<0.1, * * p<0.05, * * * p<0.01$; standard errors are in parentheses and clustered at the interview date level. Treatment status is defined by the time-invariant dummy variables PostMarch $11_{\mathrm{i}, 2011}$ and PostMay $3 \mathrm{O}_{\mathrm{i}, 2011}$. The dependent variables are dummy variables which equal one if the individual is risk averse (0-3/10 on the risk attitude scale), moderately risk averse (0-2/10 on the risk attitude scale), strongly risk averse (0-1/10 on the risk attitude scale), and extremely risk averse (0/10 on the risk attitude scale). Each column stands for one FE model similar to Equation (1).

Source: SOEP v29, 2010-2011, balanced panel, own calculations. 
Table 4: Effects on Risk Aversion by Distance to Reactors in Germany

\begin{tabular}{|c|c|c|c|}
\hline & \multicolumn{3}{|c|}{ Very Risk Averse } \\
\hline & $\begin{array}{l}\text { Within 50km } \\
\text { to Reactor }\end{array}$ & $\begin{array}{c}\text { Within } 50 \mathrm{~km} \text { to } 80 \mathrm{~km} \\
\text { to Reactor }\end{array}$ & $\begin{array}{c}\text { Nearest Reactor } \\
\text { Among Eight Oldest }\end{array}$ \\
\hline \multirow[t]{2}{*}{ PostMarch11 ${ }_{i, 2011} * 2011 *[$ Column Header] } & $0.0279 * * *$ & -0.0073 & $0.0156 * *$ \\
\hline & $(0.0081)$ & (0.0077) & $(0.0075)$ \\
\hline \multirow[t]{2}{*}{ PostMay $30_{\mathrm{i}, 2011} * 2011 *[$ Column Header] } & $-0.0763 * * *$ & 0.0187 & $-0.0489 * * *$ \\
\hline & (0.0173) & $(0.0225)$ & $(0.0176)$ \\
\hline \multirow{2}{*}{ PostMarch11 $1_{i, 2011}{ }^{*} 2011$ ("After Meltdown") } & 0.0086 & $0.0178 * * *$ & 0.0084 \\
\hline & $(0.0065)$ & $(0.0062)$ & (0.0070) \\
\hline \multirow[t]{2}{*}{ PostMay30 $_{\mathrm{i}, 2011}{ }^{*} 2011$ (“After Shutdown") } & 0.0245 & -0.0018 & 0.0287 \\
\hline & (0.0218) & (0.0117) & $(0.0247)$ \\
\hline \multicolumn{4}{|l|}{ Controls } \\
\hline Socio-Economic Characteristics & Yes & Yes & Yes \\
\hline Individual Fixed Effects & Yes & Yes & Yes \\
\hline Year Fixed Effects & Yes & Yes & Yes \\
\hline Month Fixed Effects & Yes & Yes & Yes \\
\hline Linear Time Trend & Yes & Yes & Yes \\
\hline$R^{2}$ & 0.0095 & 0.0085 & 0.0089 \\
\hline$N$ & 20,178 & 20,178 & 20,178 \\
\hline
\end{tabular}

Note: $* \mathrm{p}<0.1, * * \mathrm{p}<0.05, * * * \mathrm{p}<0.01$; standard errors are in parentheses and clustered at the interview date level. Treatment status is defined by the time-invariant dummy variables PostMarch $11_{i, 2011}$ and PostMay $30_{i, 2011}$. All distance dummy variables as indicated in the column headers are lagged by one time period to have the pre-treatment values (see Descriptive Statistics in the Appendix). The dependent variable is a dummy variable which equals one if the individual is very risk averse (0-1/10 on the risk attitude scale). Each column stands for one FE model similar to Equation (1). PostMarch11 $1_{i, 2011}$ and PostMay $3 \mathrm{O}_{\mathrm{i}, 2011}$ are time-invariant dummy variables which drop out in the FE models. As such, all three-way interaction terms could be regarded as two-way interactions.

Source: SOEP v29, 2010-2011, balanced panel, own calculations. 
Table 5: Effects on Environmental Concerns by Distance to Reactors in Germany

\begin{tabular}{|c|c|c|c|}
\hline & \multicolumn{3}{|c|}{ Very Concerned About the Environment } \\
\hline & $\begin{array}{l}\text { Within } 50 \mathrm{~km} \\
\text { to Reactor }\end{array}$ & $\begin{array}{c}\text { Within } 50 \mathrm{~km} \text { to } 80 \mathrm{~km} \\
\text { to Reactor }\end{array}$ & $\begin{array}{c}\text { Nearest Reactor } \\
\text { Among Eight Oldest }\end{array}$ \\
\hline \multirow[t]{2}{*}{ PostMarch11 1,2011} & -0.0167 & $0.0351^{* * *}$ & -0.0005 \\
\hline & (0.0136) & $(0.0127)$ & $(0.0115)$ \\
\hline \multirow[t]{2}{*}{ PostMay30 $\mathrm{i}, 2011 * 2011 *[$ Column Header] } & -0.0175 & $-0.0612^{* *}$ & $-0.0698 * * *$ \\
\hline & (0.0279) & $(0.0286)$ & $(0.0271)$ \\
\hline \multirow[t]{2}{*}{ PostMarch11 ${ }_{\mathrm{i}, 2011}{ }^{*} 2011$ ("After Meltdown") } & $0.0757^{* * *}$ & $0.0641 * * *$ & $0.0714^{* * *}$ \\
\hline & $(0.0092)$ & $(0.0095)$ & $(0.0104)$ \\
\hline \multirow[t]{2}{*}{ PostMay30 ${ }_{\mathrm{i}, 2011}{ }^{* 2011}$ ("After Shutdown") } & $-0.0918^{* * *}$ & $-0.0870 * * *$ & $-0.0592 * * *$ \\
\hline & $(0.0185)$ & (0.0169) & $(0.0225)$ \\
\hline \multicolumn{4}{|l|}{ Controls } \\
\hline Socio-Economic Characteristics & Yes & Yes & Yes \\
\hline Individual Fixed Effects & Yes & Yes & Yes \\
\hline Year Fixed Effects & Yes & Yes & Yes \\
\hline Month Fixed Effects & Yes & Yes & Yes \\
\hline Linear Time Trend & Yes & Yes & Yes \\
\hline$R^{2}$ & 0.0077 & 0.0080 & 0.0080 \\
\hline$N$ & 20,178 & 20,178 & 20,178 \\
\hline
\end{tabular}

Note: ${ }^{*} p<0.1, * * p<0.05, * * * p<0.01$; standard errors are in parentheses and clustered at the interview date level. Treatment status is defined by the time-invariant dummy variables PostMarch11 $\mathrm{i}_{\mathrm{i}, 2011}$ and PostMay $3 \mathrm{i}_{\mathrm{i}, 2011}$. All distance dummy variables as indicated in the column headers are lagged by one time period to have the pre-treatment values (see Descriptive Statistics in the Appendix). The dependent variable is a dummy variable which equals one if the individual is very concerned about the environment. Each column stands for one FE model similar to Equation (1). PostMarch11, $1_{1,2011}$ and PostMay30 $\mathrm{i}_{\mathrm{i}, 2011}$ are time-invariant dummy variables which drop out in the FE models. As such, all three-way interaction terms could be regarded as simple two-way interactions terms.

Source: SOEP v29, 2010-2011, balanced panel, own calculations. 
Table 6: Effects on Environmental Concerns by Socio-Demographics in Germany

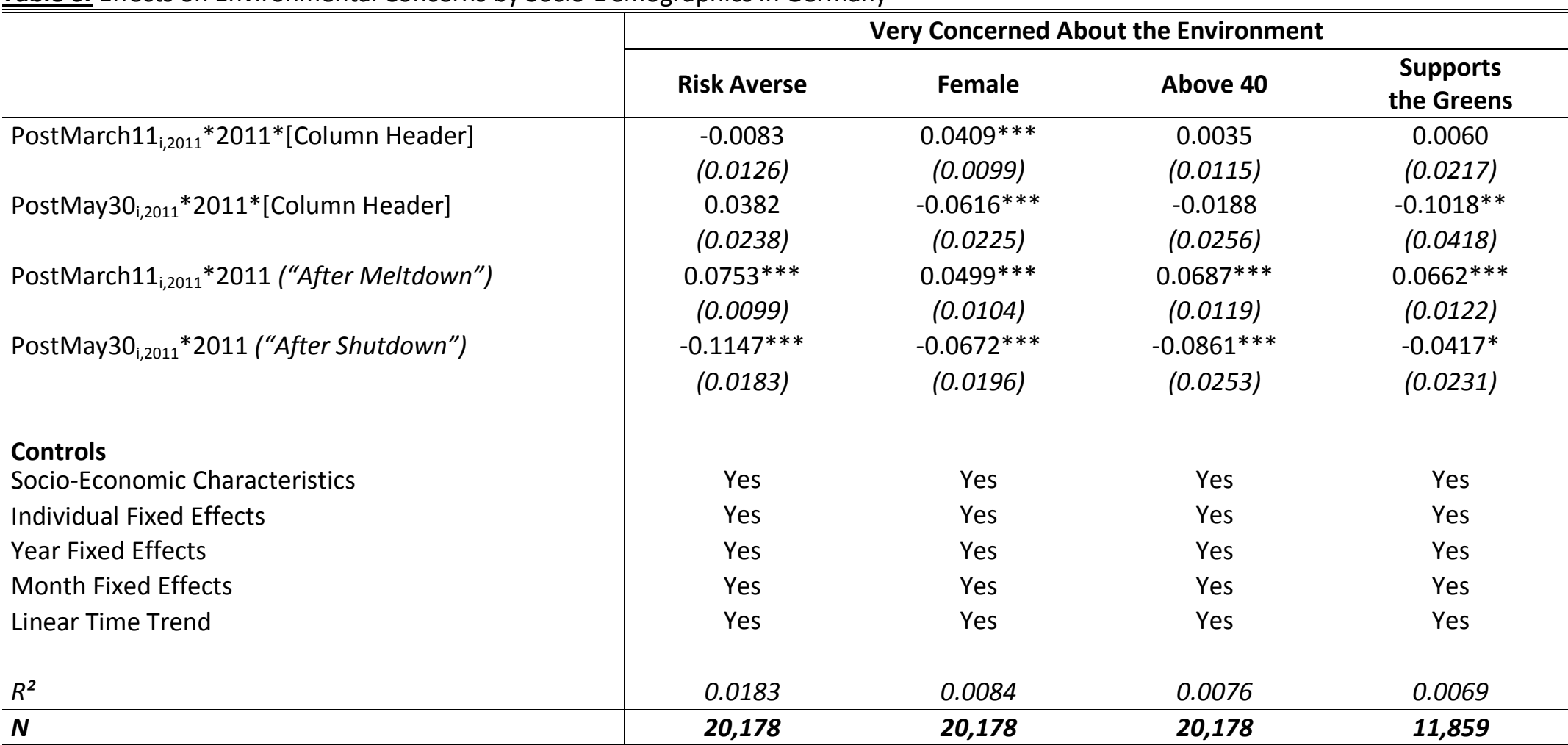

Note: ${ }^{*} p<0.1, * * p<0.05, * * * p<0.01$; standard errors are in parentheses and clustered at the interview date level. Treatment status is defined by the time-invariant dummy variables PostMarch $11_{i, 2011}$ and PostMay $30_{i, 2011}$. All socio-demographic dummy variables as indicated in the column headers are lagged by one time period to have the pre-treatment values (see Descriptive Statistics in the Appendix). The dependent variable is a dummy variable which equals one if the individual is very concerned about the environment. Each column stands for one FE model similar to Equation (1). PostMarch11 $1_{\mathrm{i}, 2011}$ and PostMay $30_{\mathrm{i}, 2011}$ are time-invariant dummy variables which drop out in the FE models. As such, all three-way interaction terms could be regarded as simple two-way interactions terms.

Source: SOEP v29, 2010-2011, balanced panel, own calculations. 


\begin{tabular}{|c|c|c|c|c|c|c|c|c|c|}
\hline & \multicolumn{7}{|c|}{ Political Party Support } & \multicolumn{2}{|c|}{ Support Intensity } \\
\hline & General & SPD & Greens & CDU/CSU & FDP & Left & $\begin{array}{c}\text { Govern- } \\
\text { ment }\end{array}$ & Strong & Weak \\
\hline & (1) & $(2)$ & (3) & (4) & (5) & (6) & (7) & (8) & (9) \\
\hline $\begin{array}{l}\text { PostMarch11 }{ }_{\mathrm{i}, 2011} * 2011 \\
\text { ("After Meltdown") }\end{array}$ & $\begin{array}{c}0.0057 \\
(0.0073)\end{array}$ & $\begin{array}{l}-0.0102 * \\
(0.0057)\end{array}$ & $\begin{array}{l}0.0175^{* * *} \\
(0.0054)\end{array}$ & $\begin{array}{c}0.0084 \\
(0.0055)\end{array}$ & $\begin{array}{l}-0.0097^{* *} \\
(0.0043)\end{array}$ & $\begin{array}{l}0.0031 \\
(0.0036)\end{array}$ & $\begin{array}{c}0.0008 \\
(0.0039)\end{array}$ & $\begin{array}{l}0.0369 * * * \\
(0.0140)\end{array}$ & $\begin{array}{l}-0.0198^{* * *} \\
(0.0065)\end{array}$ \\
\hline $\begin{array}{l}\text { PostMay30 }{ }_{\mathrm{i}, 2011} * 2011 \\
\text { ("After Shutdown") }\end{array}$ & $\begin{array}{c}0.0058 \\
(0.0116)\end{array}$ & $\begin{array}{l}-0.0204^{*} \\
(0.0115)\end{array}$ & $\begin{array}{l}-0.0055 \\
(0.0110)\end{array}$ & $\begin{array}{c}0.0035 \\
(0.0095)\end{array}$ & $\begin{array}{c}0.0111 \\
(0.0069)\end{array}$ & $\begin{array}{c}0.0011 \\
(0.0072)\end{array}$ & $\begin{array}{l}0.0134^{*} \\
(0.0071)\end{array}$ & $\begin{array}{l}-0.0373 \\
(0.0254)\end{array}$ & $\begin{array}{c}0.0166 \\
(0.0123)\end{array}$ \\
\hline \multicolumn{10}{|l|}{ Controls } \\
\hline Socio-Economic Characteristics & Yes & Yes & Yes & Yes & Yes & Yes & Yes & Yes & Yes \\
\hline Individual Fixed Effects & Yes & Yes & Yes & Yes & Yes & Yes & Yes & Yes & Yes \\
\hline Year Fixed Effects & Yes & Yes & Yes & Yes & Yes & Yes & Yes & Yes & Yes \\
\hline Month Fixed Effects & Yes & Yes & Yes & Yes & Yes & Yes & Yes & Yes & Yes \\
\hline Linear Time Trend & Yes & Yes & Yes & Yes & Yes & Yes & Yes & Yes & Yes \\
\hline$R^{2}$ & 0.0122 & 0.0079 & 0.0187 & 0.0072 & 0.0220 & 0.0079 & 0.0071 & 0.0058 & 0.0100 \\
\hline$N$ & 20,178 & 11,859 & 11,859 & 11,859 & 11,859 & 11,859 & 11,859 & 11,415 & 11,415 \\
\hline
\end{tabular}


Table 8a: Effects of the Meltdown on Well-Being, Political Outcomes, and Environmental Concerns in Switzerland

\begin{tabular}{|c|c|c|c|c|c|c|}
\hline & \multicolumn{4}{|c|}{ Waves 11-14 (2009-2012) } & \multirow{2}{*}{\multicolumn{2}{|c|}{$\begin{array}{c}\text { Waves } 11 \text { vs. } 13 \text { (2009 \& 2011) } \\
\text { Environmental Protection } \\
\text { More Important Than GDP }\end{array}$}} \\
\hline & \multicolumn{2}{|c|}{ Life Satisfaction } & \multicolumn{2}{|c|}{ Vote Green } & & \\
\hline & (1) & (2) & (3) & (4) & (5) & (6) \\
\hline PostMarch11 $1_{i, 2011}{ }^{*} 2011$ ("After Meltdown") & $\begin{array}{c}0.036 \\
(0.028)\end{array}$ & $\begin{array}{c}0.005 \\
(0.042)\end{array}$ & $\begin{array}{c}0.026 * * * \\
(0.008)\end{array}$ & $\begin{array}{c}0.010 \\
(0.011)\end{array}$ & $\begin{array}{c}0.019 * * * \\
(0.005)\end{array}$ & $\begin{array}{c}0.021 \\
(0.014)\end{array}$ \\
\hline PostMarch11 $1_{\mathrm{i}, 2011} * 2011 * 0-25 \mathrm{~km}$ Radius to Reactor & & $\begin{array}{c}0.067 \\
(0.045)\end{array}$ & & $\begin{array}{c}0.019 \\
(0.013)\end{array}$ & & $\begin{array}{l}-0.004 \\
(0.016)\end{array}$ \\
\hline PostMarch $11_{i, 2011} * 2011 * 25-50 \mathrm{~km}$ Radius to Reactor & & $\begin{array}{c}0.033 \\
(0.037)\end{array}$ & & $\begin{array}{c}0.026^{* *} \\
(0.011)\end{array}$ & & $\begin{array}{l}-0.005 \\
(0.016)\end{array}$ \\
\hline PostMarch $11_{\mathrm{i}, 2011} * 2011 * 50-80 \mathrm{~km}$ Radius to Reactor & & $\begin{array}{c}0.001 \\
(0.043)\end{array}$ & & $\begin{array}{c}0.010 \\
(0.013)\end{array}$ & & $\begin{array}{c}0.003 \\
(0.019)\end{array}$ \\
\hline \multicolumn{7}{|l|}{ Controls } \\
\hline Socio-Economic Characteristics & Yes & Yes & Yes & Yes & Yes & Yes \\
\hline Individual Fixed Effects & Yes & Yes & Yes & Yes & Yes & Yes \\
\hline Year Fixed Effects & Yes & Yes & Yes & Yes & Yes & Yes \\
\hline Month Fixed Effects & Yes & Yes & Yes & Yes & Yes & Yes \\
\hline Linear Time Trend & Yes & Yes & Yes & Yes & No & No \\
\hline$R^{2}$ & 0.011 & 0.011 & 0.010 & 0.011 & 0.011 & 0.011 \\
\hline$N$ & 14,104 & 14,104 & 14,104 & 14,104 & 9,474 & 9,474 \\
\hline
\end{tabular}

Note: ${ }^{*} p<0.1, * * p<0.05, * * * p<0.01$; standard errors are in parentheses and clustered at the interview date level. The dependent variables are defined as follows: Model (1) and (2) use life satisfaction on a scale from 0 to 10. Model (3) and (4) use a dummy variable which equals one if the individual votes for either the Swiss Ecology Party or the Green Liberals when asked: "If there was an election for the National Council tomorrow, for which party would you vote?". Model (5) and (6) use a dummy variable which equals one if the individual prefers environmental protection over economic growth. Since the Swiss Household Panel only conducts interviews from September to February in a given wave, we cannot employ month fixed effects along with PostMarch11 $1_{i, 2011}$ and PostMarch11 $1_{\mathrm{i}, 2011} * 2011$.

Source: SHP w11-14, 2009-2012, balanced panel, own calculations. 
Table 8b: Effects of the Meltdown on Well-Being and Political Outcomes in the UK

\begin{tabular}{|c|c|c|c|c|}
\hline & \multicolumn{4}{|c|}{ Waves 2-3 (2010-2012) } \\
\hline & \multicolumn{2}{|c|}{ Happiness } & \multicolumn{2}{|c|}{ Vote or Support Green Party } \\
\hline & (1) & (2) & (3) & (4) \\
\hline PostMarch11 ${ }_{i, 2011} * 2011$ (“After Meltdown") & $\begin{array}{c}0.009 \\
(0.010)\end{array}$ & $\begin{array}{c}0.008 \\
(0.011)\end{array}$ & $\begin{array}{l}-0.001 \\
(0.003)\end{array}$ & $\begin{array}{l}-0.002 \\
(0.003)\end{array}$ \\
\hline PostMay30 $_{\mathrm{i}, 2011}$ *2011 ("Placebo Nuclear Phase-Out") & $\begin{array}{c}0.004 \\
(0.008)\end{array}$ & $\begin{array}{c}0.010 \\
(0.010)\end{array}$ & $\begin{array}{c}0.000 \\
(0.002)\end{array}$ & $\begin{array}{c}0.001 \\
(0.003)\end{array}$ \\
\hline PostMarch $11_{\mathrm{i}, 2011} * 2011 * 0-25 \mathrm{~km}$ Radius to Reactor & & $\begin{array}{l}-0.036 \\
(0.026)\end{array}$ & & $\begin{array}{c}0.026 * * * \\
(0.009)\end{array}$ \\
\hline PostMarch11 $1_{i, 2011} * 2011 * 25-50 \mathrm{~km}$ Radius to Reactor & & $\begin{array}{c}0.002 \\
(0.021)\end{array}$ & & $\begin{array}{l}-0.003 \\
(0.006)\end{array}$ \\
\hline PostMarch $11_{i, 2011} * 2011 * 50-80 \mathrm{~km}$ Radius to Reactor & & $\begin{array}{c}0.009 \\
(0.018)\end{array}$ & & $\begin{array}{c}0.003 \\
(0.005)\end{array}$ \\
\hline PostMay30 ${ }_{\mathrm{i}, 2011} * 2011 * 0-25 \mathrm{~km}$ Radius to Reactor & & $\begin{array}{l}-0.002 \\
(0.035)\end{array}$ & & $\begin{array}{l}-0.013 \\
(0.012)\end{array}$ \\
\hline PostMay30 ${ }_{\mathrm{i}, 2011} * 2011 * 25-50 \mathrm{~km}$ Radius to Reactor & & $\begin{array}{l}-0.024 \\
(0.025)\end{array}$ & & $\begin{array}{l}-0.000 \\
(0.007)\end{array}$ \\
\hline PostMay30 ${ }_{\mathrm{i}, 2011} * 2011 * 50-80 \mathrm{~km}$ Radius to Reactor & & $\begin{array}{l}-0.024 \\
(0.021)\end{array}$ & & $\begin{array}{c}0.001 \\
(0.006)\end{array}$ \\
\hline \multicolumn{5}{|l|}{ Controls } \\
\hline Socio-Economic Characteristics & Yes & Yes & Yes & Yes \\
\hline Individual, Year, and Month Fixed Effects, Linear Time Trend & Yes & Yes & Yes & Yes \\
\hline$R^{2}$ & 0.006 & 0.006 & 0.003 & 0.003 \\
\hline$N$ & 46,406 & 46,406 & 46,406 & 46,406 \\
\hline
\end{tabular}


Table 9: Comparison of Meltdown and (Placebo) Policy Effects between Fukushima and Chernobyl

\begin{tabular}{|c|c|c|c|c|c|}
\hline & \multicolumn{5}{|c|}{ Very Concerned About the Environment } \\
\hline & $\begin{array}{c}\text { Fukushima OLS } \\
2009-2012\end{array}$ & $\begin{array}{c}\text { Fukushima FE } \\
2009-2012\end{array}$ & & $\begin{array}{c}\text { Chernobyl OLS } \\
1984-1989\end{array}$ & $\begin{array}{c}\text { Chernobyl FE } \\
1984-1989\end{array}$ \\
\hline PostMarch11 $1_{\mathrm{i}, 2011} * 2011$ & $0.0712^{* * *}$ & $0.0797^{* * *}$ & PostApril26 $6_{i, 1986}{ }^{19886}$ & $0.1025^{* * *}$ & $0.1213^{* * *}$ \\
\hline ("After Meltdown") & $(0.0116)$ & (0.0104) & ("After Meltdown") & $(0.0175)$ & $(0.0151)$ \\
\hline $\begin{array}{l}\text { PostMay30 }{ }_{\mathrm{i}, 2011} * 2011 \\
\text { ("After Shutdown") }\end{array}$ & $\begin{array}{c}-0.0871 * * * \\
(0.0191)\end{array}$ & $\begin{array}{c}-0.1078 * * * \\
(0.0156)\end{array}$ & $\begin{array}{r}\text { PostJuly15 } 1,1986 \text { *1986 } \\
\text { ("Placebo Policy") }\end{array}$ & $\begin{array}{l}-0.0183 \\
(0.1686)\end{array}$ & $\begin{array}{l}-0.0247 \\
(0.0251)\end{array}$ \\
\hline 2010 & $\begin{array}{c}0.0338^{* * *} \\
(0.0054)\end{array}$ & $\begin{array}{c}0.0348^{* * *} \\
(0.0042)\end{array}$ & 1985 & $\begin{array}{c}-0.0291^{* * *} \\
(0.0100)\end{array}$ & $\begin{array}{c}-0.3000^{* * *} \\
(0.0088)\end{array}$ \\
\hline 2011 & $\begin{array}{c}0.0003 \\
(0.0082)\end{array}$ & $\begin{array}{c}0.0092 \\
(0.0068)\end{array}$ & 1986 & $\begin{array}{c}-0.0869 * * * \\
(0.0116)\end{array}$ & $\begin{array}{c}-0.1034^{* * *} \\
(0.0102)\end{array}$ \\
\hline 2012 & $\begin{array}{c}0.0003 \\
(0.0002)\end{array}$ & $\begin{array}{l}-0.0002 \\
(0.0001)\end{array}$ & 1987 & $\begin{array}{c}0.0671 * * * \\
(0.0108)\end{array}$ & $\begin{array}{c}0.0580^{* * *} \\
(0.0097)\end{array}$ \\
\hline & & & 1988 & $\begin{array}{c}0.0494 * * * \\
(0.0106)\end{array}$ & $\begin{array}{c}0.0375^{* * *} \\
(0.0092)\end{array}$ \\
\hline & & & 1989 & $\begin{array}{c}0.1068^{* * *} \\
(0.0113)\end{array}$ & $\begin{array}{c}0.0984^{* * *} \\
(0.0093)\end{array}$ \\
\hline Controls & & & & & \\
\hline Socio-Economic Characteristics & Yes & Yes & & Yes & Yes \\
\hline Year and Month Fixed Effects & Yes & Yes & & Yes & Yes \\
\hline Linear Time Trend & Yes & Yes & & Yes & Yes \\
\hline$R^{2}$ & 0.0121 & 0.0087 & & 0.0655 & 0.0281 \\
\hline$N$ & 57,492 & 57,492 & & 62,540 & 62,540 \\
\hline
\end{tabular}

Note: $* p<0.1, * * p<0.05, * * * p<0.01$; standard errors are in parentheses and clustered at the interview date level. Treatment status is defined by the time-invariant dummy variables PostMarch11 $1_{i, 2011}$ and PostMay30 ${ }_{i, 2011}$ for Fukushima and PostApril26 ${ }_{i, 1986}$ and PostJuly15 ${ }_{i, 1986}$ for Chernobyl, all of which drop out in the FE models. To save space, they are not displayed. While April 26, 1986, was the date of the disaster, the actual treatment status for Chernobyl is defined by interviews that took place after April 28 , 1986 , as the disaster only became public two days later. The dependent variable is a dummy variable which equals one if the individual is very concerned about the environment. PostJuly $15_{i, 1986}$ is the placebo policy date for Chernobyl, 81 days after the disaster.

Source: SOEP v29, 1984-1989 and 2009-2012, unbalanced panel, own calculations. 


\section{Appendix: Descriptive Statistics - Germany (SOEP)}

\section{Dependent Variables}

Very Concerned About the Environment

Very Concerned About Climate Change

Very Concerned About Job Security

Very Concerned About Health

Very Concerned About the Economy

Very Concerned About Crime

Life Satisfaction

Happiness

Sadness

Risk Averse

Moderately Risk Averse

Very Risk Averse

Extremely Risk Averse

Supports Political Party

Supports SPD

Supports the Greens

Supports CDU/CSU

Supports FDP

Supports the Left

Supports the Government

Strong Political Party Support

Weak Political Party Support

\section{Demographic Characteristics}

Age

Age Squared/100

Female

Married

Single

Disabled

No German Nationality

Number of Children in Household

\section{Educational Characteristics}

In School

Lower Than Secondary Degree

Secondary Degree

Tertiary Degree

\section{Labor Market Characteristics}

Full-Time Employed

Part-Time Employed

Out of the Labor Force

\begin{tabular}{|c|c|c|c|c|}
\hline Mean & Std. Dev. & Min. & Max. & Obs. \\
\hline 0.3090 & 0.4621 & 0 & 1 & 20,178 \\
\hline 0.3002 & 0.4584 & 0 & 1 & 20,178 \\
\hline 0.1121 & 0.3155 & 0 & 1 & 11,526 \\
\hline 0.2022 & 0.4016 & 0 & 1 & 20,178 \\
\hline 0.2946 & 0.4559 & 0 & 1 & 20,178 \\
\hline 0.3458 & 0.4756 & 0 & 1 & 20,178 \\
\hline 6.9952 & 1.7295 & 0 & 10 & 20,178 \\
\hline 0.1349 & 0.3417 & 0 & 1 & 20,178 \\
\hline 0.5414 & 0.4983 & 0 & 1 & 20,178 \\
\hline 0.3741 & 0.4839 & 0 & 1 & 20,178 \\
\hline 0.2194 & 0.4138 & 0 & 1 & 20,178 \\
\hline 0.1007 & 0.3009 & 0 & 1 & 20,178 \\
\hline 0.0501 & 0.2181 & 0 & 1 & 20,178 \\
\hline 0.4949 & 0.5000 & 0 & 1 & 20,178 \\
\hline 0.3014 & 0.4589 & 0 & 1 & 11,859 \\
\hline 0.1479 & 0.3550 & 0 & 1 & 11,859 \\
\hline 0.4045 & 0.4908 & 0 & 1 & 11,859 \\
\hline 0.0471 & 0.2119 & 0 & 1 & 11,859 \\
\hline 0.0739 & 0.2616 & 0 & 1 & 11,859 \\
\hline 0.4537 & 0.4979 & 0 & 1 & 11,859 \\
\hline 0.4437 & 0.4968 & 0 & 1 & 11,415 \\
\hline 0.0590 & 0.2357 & 0 & 1 & 11,415 \\
\hline 51.4397 & 17.0461 & 18 & 101 & 20,178 \\
\hline 29.3660 & 17.7809 & 3.2400 & 102.0100 & 20,178 \\
\hline 0.5260 & 0.4993 & 0 & 1 & 20,178 \\
\hline 0.6385 & 0.4805 & 0 & 1 & 20,178 \\
\hline 0.2119 & 0.4087 & 0 & 1 & 20,178 \\
\hline 0.1425 & 0.3496 & 0 & 1 & 20,178 \\
\hline 0.0443 & 0.2057 & 0 & 1 & 20,178 \\
\hline 0.8252 & 1.1950 & 0 & 12 & 20,178 \\
\hline 0.0127 & 0.1119 & 0 & 1 & 20,178 \\
\hline 0.1315 & 0.3380 & 0 & 1 & 20,178 \\
\hline 0.5337 & 0.4989 & 0 & 1 & 20,178 \\
\hline 0.3221 & 0.4673 & 0 & 1 & 20,178 \\
\hline 0.3946 & 0.4888 & 0 & 1 & 20,178 \\
\hline 0.1198 & 0.3247 & 0 & 1 & 20,178 \\
\hline 0.4164 & 0.4930 & 0 & 1 & 20,178 \\
\hline
\end{tabular}


On Maternity Leave

Unemployed

Household Income

\section{Heterogeneity}

Within 50km to Reactor (Lagged)

Within $50 \mathrm{~km}$ to $80 \mathrm{~km}$ to Reactor (Lagged)

Nearest Reactor Among Eight Oldest (Lagged)

Risk Averse (Lagged)

Above 40 (Lagged)

Supports the Greens (Lagged)

Source: SOEP v29, 2010-2011, own calculations.

$\begin{array}{ccccc}0.0178 & 0.1324 & 0 & 1 & 20,178 \\ 0.0507 & 0.2194 & 0 & 1 & 20,178 \\ 2,832 & 1,583 & 0 & 47,256 & 20,178 \\ & & & & \\ 0.2834 & 0.4506 & 0 & 1 & 20,178 \\ 0.2000 & 0.4000 & 0 & 1 & 20,178 \\ 0.4935 & 0.5000 & 0 & 1 & 20,178 \\ 0.3741 & 0.4839 & 0 & 1 & 20,178 \\ 0.7350 & 0.4413 & 0 & 1 & 20,178 \\ 0.1347 & 0.3415 & 0 & 1 & 11,859\end{array}$

0.1347 


\section{Appendix: Descriptive Statistics - Switzerland (SHP)}

\begin{tabular}{|c|c|c|c|c|c|}
\hline & Mean & Std. Dev. & Min. & Max. & Obs. \\
\hline & & & & & \\
\hline $\begin{array}{l}\text { Dependent Variables } \\
\text { Life Satisfaction }\end{array}$ & 8.0269 & 1.3094 & 0 & 10 & 14,104 \\
\hline Votes Green & 0.1466 & 0.3537 & 0 & 1 & 14,104 \\
\hline Env. Protection More Important Than GDP & 0.5088 & 0.4999 & 0 & 1 & 9,474 \\
\hline \multicolumn{6}{|l|}{ Demographic Characteristics } \\
\hline Age & 51.5468 & 16.0513 & 16 & 96 & 14,104 \\
\hline Age Squared/100 & 29.1470 & 16.5089 & 2.5600 & 92.1600 & 14,104 \\
\hline Female & 0.5255 & 0.4994 & 0 & 1 & 14,104 \\
\hline Single & 0.2119 & 0.4087 & 0 & 1 & 14,104 \\
\hline Married & 0.6326 & 0.4821 & 0 & 1 & 14,104 \\
\hline Divorced & 0.0915 & 0.2884 & 0 & 1 & 14,104 \\
\hline Separated & 0.0132 & 0.1141 & 0 & 1 & 14,104 \\
\hline Widowed & 0.0488 & 0.2154 & 0 & 1 & 14,104 \\
\hline Registered Partnership & 0.0020 & 0.0445 & 0 & 1 & 14,104 \\
\hline Children Under 17 in Household & 0.5610 & 0.9592 & 0 & 5 & 14,104 \\
\hline No Swiss Nationality & 0.0552 & 0.2284 & 0 & 1 & 14,104 \\
\hline \multicolumn{6}{|l|}{ Educational Characteristics } \\
\hline Incomplete School Education & 0.0137 & 0.1162 & 0 & 1 & 14,104 \\
\hline Elementary School & 0.0664 & 0.2489 & 0 & 1 & 14,104 \\
\hline Compulsory Secondary Education & 0.4275 & 0.4947 & 0 & 1 & 14,104 \\
\hline \multirow{2}{*}{$\begin{array}{l}\text { A-Level Equiv., Master, Technical School } \\
\text { Voc./Acad. High School Degree or Higher }\end{array}$} & 0.2265 & 0.4186 & 0 & 1 & 14,104 \\
\hline & 0.2660 & 0.4419 & 0 & 1 & 14,104 \\
\hline \multicolumn{6}{|l|}{ Labor Market Characteristics } \\
\hline Regularly Employed & 0.5177 & 0.4997 & 0 & 1 & 14,104 \\
\hline Managerial Position & 0.1078 & 0.3101 & 0 & 1 & 14,104 \\
\hline Contract Position & 0.0564 & 0.2308 & 0 & 1 & 14,104 \\
\hline Self-Employed & 0.0904 & 0.2868 & 0 & 1 & 14,104 \\
\hline Unemployed & 0.0095 & 0.0970 & 0 & 1 & 14,104 \\
\hline Student & 0.0200 & 0.1400 & 0 & 1 & 14,104 \\
\hline Retired & 0.2136 & 0.4098 & 0 & 1 & 14,104 \\
\hline Disabled (Not Working) & 0.0160 & 0.1253 & 0 & 1 & 14,104 \\
\hline Domestic Tasks or Care & 0.0305 & 0.1719 & 0 & 1 & 14,104 \\
\hline Other Non Working & 0.0184 & 0.1345 & 0 & 1 & 14,104 \\
\hline Household Income & 125 & 119 & 1 & 6,185 & 14,104 \\
\hline Heterogeneity & & & & & \\
\hline Within $0-25 \mathrm{~km}$ Radius to Reactor & 0.2683 & 0.4431 & 0 & 1 & 14,104 \\
\hline Within $25-50 \mathrm{~km}$ Radius to Reactor & 0.3883 & 0.4874 & 0 & 1 & 14,104 \\
\hline Within $50-80 \mathrm{~km}$ Radius to Reactor & 0.1766 & 0.3814 & 0 & 1 & 14,104 \\
\hline
\end{tabular}


Appendix: Descriptive Statistics - United Kingdom (Understanding Society)

\begin{tabular}{|c|c|c|c|c|c|}
\hline \multirow{2}{*}{\multicolumn{6}{|c|}{ Dependent Variables }} \\
\hline & & & & & \\
\hline Happiness & 2.9462 & 0.5451 & 1 & 4 & 46,406 \\
\hline Supports Green Party & 0.0353 & 0.1845 & 0 & 1 & 46,406 \\
\hline \multicolumn{6}{|l|}{ Demographic Characteristics } \\
\hline Age & 48.5198 & 17.1784 & 16 & 99 & 46,406 \\
\hline Age Squared/100 & 26.4926 & 17.2949 & 256.0000 & $9,801.0000$ & 46,406 \\
\hline Female & 0.5619 & 0.4962 & 0 & 1 & 46,406 \\
\hline Single & 0.2638 & 0.4407 & 0 & 1 & 46,406 \\
\hline Married & 0.5573 & 0.4967 & 0 & 1 & 46,406 \\
\hline Separated & 0.0213 & 0.1444 & 0 & 1 & 46,406 \\
\hline Divorced & 0.0982 & 0.2976 & 0 & 1 & 46,406 \\
\hline Widowed & 0.0594 & 0.2364 & 0 & 1 & 46,406 \\
\hline Number of Children in Household & 0.5246 & 0.9280 & 0 & 9 & 46,406 \\
\hline \multicolumn{6}{|l|}{ Educational Characteristics } \\
\hline Higher Degree & 0.2363 & 0.4248 & 0 & 1 & 46,406 \\
\hline Degree & 0.1249 & 0.3306 & 0 & 1 & 46,406 \\
\hline A-Level (etc.) & 0.1973 & 0.3980 & 0 & 1 & 46,406 \\
\hline GCSE (etc.) & 0.2088 & 0.4065 & 0 & 1 & 46,406 \\
\hline Other Qualification & 0.1020 & 0.3026 & 0 & 1 & 46,406 \\
\hline No Qualification & 0.1306 & 0.3370 & 0 & 1 & 46,406 \\
\hline \multicolumn{6}{|l|}{ Labor Market Characteristics } \\
\hline Paid Employment & 0.4903 & 0.4999 & 0 & 1 & 46,406 \\
\hline Self-Employed & 0.0757 & 0.2645 & 0 & 1 & 46,406 \\
\hline Unemployed & 0.0499 & 0.2178 & 0 & 1 & 46,406 \\
\hline Retired & 0.2338 & 0.4233 & 0 & 1 & 46,406 \\
\hline Family Care, Home, Maternity Leave & 0.0659 & 0.2482 & 0 & 1 & 46,406 \\
\hline Student & 0.0431 & 0.2031 & 0 & 1 & 46,406 \\
\hline Sick or Disabled & 0.0353 & 0.1845 & 0 & 1 & 46,406 \\
\hline Other & 0.0059 & 0.0766 & 0 & 1 & 46,406 \\
\hline Household Income & 3,685 & 2,909 & 0 & 20,000 & 46,406 \\
\hline \multicolumn{6}{|l|}{ Heterogeneity } \\
\hline Within $0-25 \mathrm{~km}$ Radius to Reactor & 0.0305 & 0.1720 & 0 & 1 & 46,406 \\
\hline Within $25-50 \mathrm{~km}$ Radius to Reactor & 0.1074 & 0.3096 & 0 & 1 & 46,406 \\
\hline Within $50-80 \mathrm{~km}$ Radius to Reactor & 0.1908 & 0.3929 & 0 & 1 & 46,406 \\
\hline
\end{tabular}




\section{Online Appendix}

Figure A1: SOEP Respondents Who Are Very Concerned About the Environmental in 2011

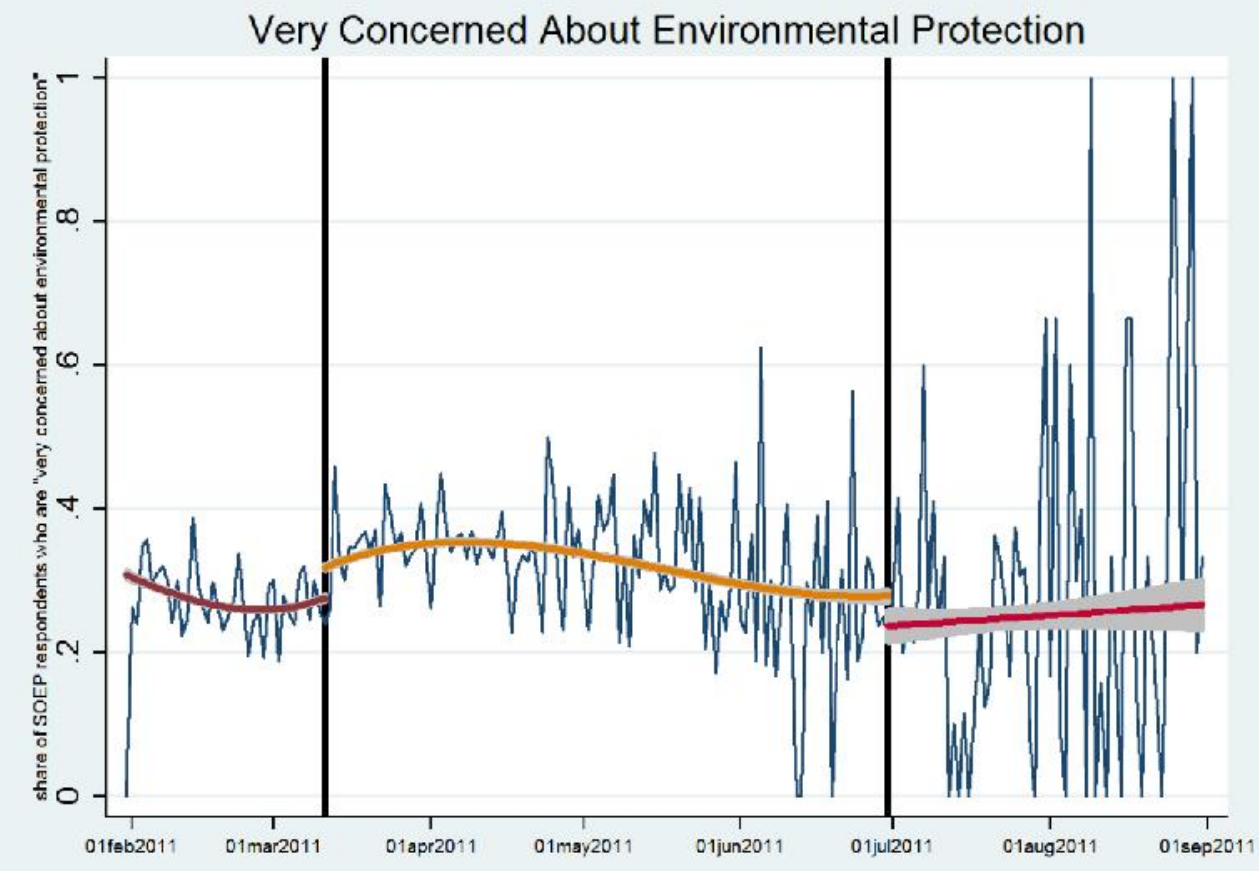

Figure A2: SOEP Respondents Who Are Very Concerned About Environmental Protection in 1986

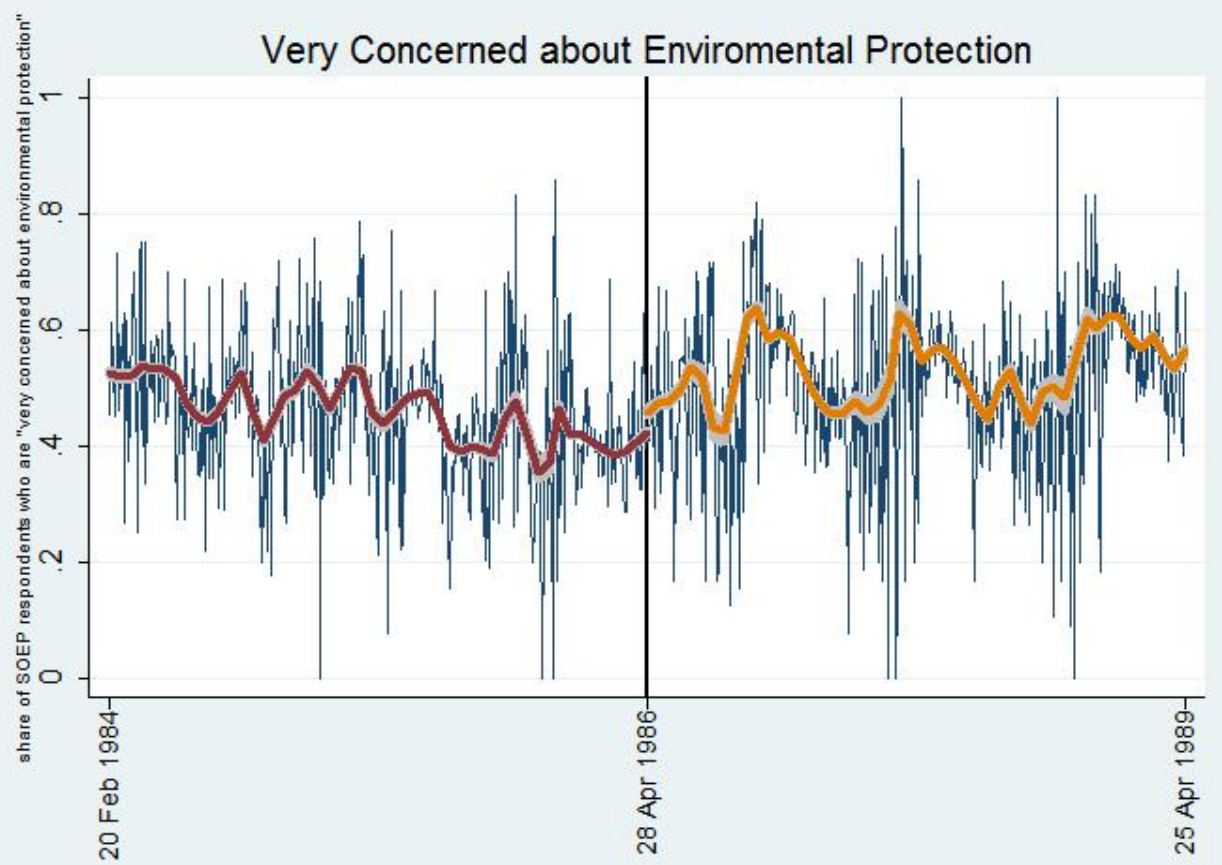

Note: Dates with less than six observations have been dropped from the sample. 
Table A1: Balancing Properties between Treatment and Control Group, 2010-2011, Germany

\begin{tabular}{|c|c|c|c|}
\hline Demographic Characteristics & $\begin{array}{c}\text { Interview after } \\
\text { March 11, } 2011 \\
\text { (treatment group) } \\
\text { Mean }\end{array}$ & $\begin{array}{c}\text { Interview before } \\
\text { March 11, } 2011 \\
\text { (control group) } \\
\text { Mean }\end{array}$ & $\begin{array}{c}\text { Normalized } \\
\text { Difference }\end{array}$ \\
\hline Age & 51.8324 & 50.3973 & 0.1368 \\
\hline Age Squared/100 & 29.8230 & 28.1530 & 0.1459 \\
\hline Female & 0.5282 & 0.5201 & 0.0159 \\
\hline Married & 0.6367 & 0.6432 & 0.0169 \\
\hline Single & 0.2086 & 0.2208 & 0.0445 \\
\hline Disabled & 0.1464 & 0.1324 & 0.0651 \\
\hline No German Nationality & 0.0420 & 0.0502 & 0.0482 \\
\hline Number of Children in Household & 0.8356 & 0.7977 & 0.0344 \\
\hline \multicolumn{4}{|l|}{ Educational Characteristics } \\
\hline In School & 0.0132 & 0.0114 & 0.0328 \\
\hline Lower Than Secondary Degree & 0.1384 & 0.1132 & 0.0733 \\
\hline Secondary Degree & 0.5336 & 0.5339 & 0.0052 \\
\hline Tertiary Degree & 0.3148 & 0.3415 & 0.0510 \\
\hline \multicolumn{4}{|l|}{ Labor Market Characteristics } \\
\hline Full-Time Employed & 0.3810 & 0.4306 & 0.0985 \\
\hline Part-Time Employed & 0.1152 & 0.1318 & 0.0460 \\
\hline Out of the Labor Force & 0.4337 & 0.3705 & 0.1353 \\
\hline On Maternity Leave & 0.0182 & 0.0168 & 0.0061 \\
\hline Unemployed & 0.0542 & 0.0413 & 0.0127 \\
\hline Household Income & $2,756.2142$ & $3,041.9783$ & 0.1602 \\
\hline \multicolumn{4}{|l|}{ Heterogeneity } \\
\hline Within $50 \mathrm{~km}$ to Reactor (Lagged) & 0.2837 & 0.2825 & 0.0038 \\
\hline Within $50 \mathrm{~km}$ to $80 \mathrm{~km}$ to Reactor (Lagged) & 0.1978 & 0.2059 & 0.0226 \\
\hline Nearest Reactor Among Eight Oldest (Lagged) & 0.4846 & 0.5168 & 0.0735 \\
\hline Risk Averse (Lagged) & 0.4040 & 0.3939 & 0.0211 \\
\hline Above 40 (Lagged) & 0.7412 & 0.7186 & 0.0557 \\
\hline Supports the Greens (Lagged) & 0.1284 & 0.1498 & 0.0512 \\
\hline$N$ & 14,656 & 5,522 & - \\
\hline \multicolumn{4}{|c|}{$\begin{array}{l}\text { Note: The last column shows the normalized difference which has been calculated according to } \Delta s=\left(\overline{s_{1}}-\overline{s_{0}}\right) / \sqrt{\sigma_{1}^{2}+\sigma_{0}^{2}} \text {, with } \overline{s_{1}} \\
\text { and } \overline{s_{0}} \text { denoting average covariate values for treatment and control group, respectively. } \sigma \text { denotes the variance. As a rule of } \\
\text { thumb, normalized differences exceeding } 0.25 \text { indicate non-balanced observables that might lead to sensitive results (Imbens and } \\
\text { Wooldridge, 2009). } \\
\text { Source: SOEP } v 29,2010-2011 \text {, own calculations }\end{array}$} \\
\hline
\end{tabular}


Table A2: Balancing Properties between Treatment and Control Group, 2009-2012, Switzerland

\begin{tabular}{|c|c|c|c|}
\hline Demographic Characteristics & $\begin{array}{c}\text { Interview After } \\
\text { March 11, } 2011 \\
\text { (Treatment Group) } \\
\text { Mean }\end{array}$ & $\begin{array}{c}\text { Interview Before } \\
\text { March 11, } 2011 \\
\text { (Control Group) } \\
\text { Mean }\end{array}$ & $\begin{array}{c}\text { Normalized } \\
\text { Difference }\end{array}$ \\
\hline Age & 52.5468 & 50.5468 & 0.0883 \\
\hline Age Squared/100 & 30.1779 & 28.1160 & 0.0885 \\
\hline Female & 0.5255 & 0.5255 & 0.0000 \\
\hline Single & 0.2031 & 0.2208 & 0.0307 \\
\hline Married & 0.6354 & 0.6298 & 0.0083 \\
\hline Divorced & 0.0946 & 0.0885 & 0.0150 \\
\hline Separated & 0.0129 & 0.0135 & 0.0035 \\
\hline Widowed & 0.0518 & 0.0458 & 0.0196 \\
\hline Registered Partnership & 0.0023 & 0.0017 & 0.0090 \\
\hline Children Under 17 in household & 0.5172 & 0.6048 & 0.0647 \\
\hline Foreign Nationality & 0.0547 & 0.0557 & 0.0031 \\
\hline \multicolumn{4}{|l|}{ Educational Characteristics } \\
\hline Incomplete School Education & 0.0095 & 0.0179 & 0.0510 \\
\hline Elementary School & 0.0613 & 0.0715 & 0.0290 \\
\hline Compulsory Secondary Education & 0.4290 & 0.4260 & 0.0043 \\
\hline A-Level Equiv., Master, Technical School & 0.2266 & 0.2265 & 0.0002 \\
\hline Voc./Acad. High School Degree or Higher & 0.2737 & 0.2582 & 0.0247 \\
\hline \multicolumn{4}{|l|}{ Labor Market Characteristics } \\
\hline Regularly Employed & 0.6900 & 0.7131 & 0.0357 \\
\hline Managerial Position & 0.1044 & 0.1112 & 0.0155 \\
\hline Contract Position & 0.0519 & 0.0610 & 0.0278 \\
\hline Self-Employed & 0.0888 & 0.0920 & 0.0080 \\
\hline Unemployed & 0.0092 & 0.0098 & 0.0041 \\
\hline Student & 0.0155 & 0.0245 & 0.0459 \\
\hline Retired & 0.2300 & 0.1971 & 0.0568 \\
\hline Disabled (Not Working) & 0.0169 & 0.0150 & 0.0104 \\
\hline Domestic Tasks or Care & 0.0278 & 0.0332 & 0.0222 \\
\hline Other Non Working & 0.0199 & 0.0170 & 0.0149 \\
\hline Household Income & 127.1445 & 123.4470 & 0.0219 \\
\hline \multicolumn{4}{|l|}{ Heterogeneity } \\
\hline Within $0-25 \mathrm{~km}$ Radius to Reactor & 0.2683 & 0.2683 & 0.0000 \\
\hline Within $25-50 \mathrm{~km}$ Radius to Reactor & 0.3883 & 0.3883 & 0.0000 \\
\hline Within $50-80 \mathrm{~km}$ Radius to Reactor & 0.1771 & 0.1761 & 0.0018 \\
\hline$N$ & 7,052 & 7,052 & - \\
\hline \multicolumn{4}{|c|}{$\begin{array}{l}\text { Note: The last column shows the normalized difference which has been calculated according to } \Delta s=\left(\overline{s_{1}}-\overline{s_{0}}\right) / \sqrt{\sigma_{1}^{2}+\sigma_{0}^{2}} \text {, with } \overline{s_{1}} \\
\text { and } \overline{s_{0}} \text { denoting average covariate values for treatment and control group, respectively. } \sigma \text { denotes the variance. As a rule of } \\
\text { thumb, normalized differences exceeding } 0.25 \text { indicate non-balanced observables that might lead to sensitive results (Imbens and } \\
\text { Wooldridge, 2009). } \\
\text { Source: SHP w11-14, 2009-2012, own calculations. }\end{array}$} \\
\hline
\end{tabular}


Table A3: Balancing Properties Between Treatment and Control Group, 2010-2012, UK

\begin{tabular}{|c|c|c|c|}
\hline Demographic Characteristics & $\begin{array}{c}\text { Interview After } \\
\text { March 11, } 2011 \\
\text { (Treatment Group) } \\
\text { Mean }\end{array}$ & $\begin{array}{c}\text { Interview Before } \\
\text { March 11, } 2011 \\
\text { (Control Group) } \\
\text { Mean } \\
\end{array}$ & $\begin{array}{c}\text { Normalized } \\
\text { Difference }\end{array}$ \\
\hline Age & 48.7660 & 48.1026 & 0.0273 \\
\hline Age Squared/100 & $2,672.4283$ & $2,609.9976$ & 0.0255 \\
\hline Female & 0.5630 & 0.5599 & 0.0044 \\
\hline Single & 0.2623 & 0.2663 & 0.0064 \\
\hline Married & 0.5582 & 0.5557 & 0.0035 \\
\hline Separated & 0.0215 & 0.0210 & 0.0026 \\
\hline Divorced & 0.0988 & 0.0972 & 0.0039 \\
\hline Widowed & 0.0592 & 0.0599 & 0.0020 \\
\hline Number of Children & 0.5268 & 0.5210 & 0.0044 \\
\hline \multicolumn{4}{|l|}{ Educational Characteristics } \\
\hline Higher Degree & 0.2408 & 0.2289 & 0.0198 \\
\hline Degree & 0.1285 & 0.1189 & 0.0205 \\
\hline A-Level (etc.) & 0.1993 & 0.1940 & 0.0095 \\
\hline GCSE (etc.) & 0.2043 & 0.2165 & 0.0210 \\
\hline Other Qualification & 0.1005 & 0.1045 & 0.0094 \\
\hline No Qualification & 0.1266 & 0.1373 & 0.0222 \\
\hline \multicolumn{4}{|l|}{ Labor Market Characteristics } \\
\hline Paid Employment & 0.4864 & 0.4970 & 0.0150 \\
\hline Self-Employed & 0.0773 & 0.0730 & 0.0115 \\
\hline Unemployed & 0.0505 & 0.0490 & 0.0048 \\
\hline Retired & 0.2380 & 0.2267 & 0.0190 \\
\hline Family Care, Mome, Maternity Leave & 0.0660 & 0.0659 & 0.0002 \\
\hline Student & 0.0410 & 0.0467 & 0.0197 \\
\hline Sick or Disabled & 0.0351 & 0.0356 & 0.0019 \\
\hline Other & 0.0058 & 0.0062 & 0.0037 \\
\hline Household Income & $3,716.5781$ & $3,631.6910$ & 0.0207 \\
\hline \multicolumn{4}{|l|}{ Heterogeneity } \\
\hline Within $0-25 \mathrm{~km}$ Radius to Reactor & 0.0327 & 0.0269 & 0.0240 \\
\hline Within $25-50 \mathrm{~km}$ Radius to Reactor & 0.1117 & 0.1000 & 0.0270 \\
\hline Within 50-100km Radius to Reactor & 0.2057 & 0.1657 & 0.0729 \\
\hline $\mathbf{N}$ & 29,183 & 17,223 & - \\
\hline \multicolumn{4}{|c|}{$\begin{array}{l}\text { Note: The last column shows the normalized difference which has been calculated according to } \Delta s=\left(\overline{s_{1}}-\overline{s_{0}}\right) / \sqrt{\sigma_{1}^{2}+\sigma_{0}^{2}} \text {, with } \overline{s_{1}} \\
\text { and } \overline{s_{0}} \text { denoting average covariate values for treatment and control group, respectively. } \sigma \text { denotes the variance. As a rule of } \\
\text { thumb, normalized differences exceeding } 0.25 \text { indicate non-balanced observables that might lead to sensitive results (Imbens and } \\
\text { Wooldridge, 2009). } \\
\text { Source: Understanding Society, w2-3, 2010-2012, own calculations. }\end{array}$} \\
\hline
\end{tabular}


Table A4: Determinants of Environmental Concerns

\begin{tabular}{|c|c|c|}
\hline & OLS & FE \\
\hline \multirow[t]{2}{*}{ Age } & $0.0077 * * *$ & \\
\hline & (0.0015) & \\
\hline \multirow[t]{2}{*}{ Age Squared/100 } & $-0.0074 * * *$ & \\
\hline & $(0.0000)$ & \\
\hline \multirow[t]{2}{*}{ Female } & $0.0710 * * *$ & \\
\hline & (0.0090) & \\
\hline \multirow[t]{2}{*}{ Married } & -0.0145 & -0.0185 \\
\hline & $(0.0111)$ & $(0.0350)$ \\
\hline \multirow[t]{2}{*}{ Single } & 0.0035 & -0.0062 \\
\hline & $(0.0160)$ & $(0.0496)$ \\
\hline \multirow[t]{2}{*}{ Disabled } & $0.0516 * * *$ & $0.0343^{*}$ \\
\hline & (0.0098) & (0.0198) \\
\hline \multirow[t]{2}{*}{ No German Nationality } & 0.0096 & -0.0563 \\
\hline & $(0.0180)$ & (0.1649) \\
\hline \multirow[t]{2}{*}{ Number of Children in Household } & $-0.0108 * * *$ & $-0.0047^{*}$ \\
\hline & (0.0041) & (0.0025) \\
\hline \multirow[t]{2}{*}{ In School } & $0.0625^{*}$ & -0.0157 \\
\hline & $(0.0343)$ & $(0.0508)$ \\
\hline \multirow[t]{2}{*}{ Lower Than Secondary Degree } & -0.0126 & $-0.2148 * * *$ \\
\hline & (0.0107) & $(0.0620)$ \\
\hline \multirow[t]{2}{*}{ Secondary Degree } & -0.0086 & -0.0324 \\
\hline & $(0.0126)$ & (0.0378) \\
\hline \multirow[t]{2}{*}{ Full-Time Employed } & $-0.0610 * * *$ & $-0.0576 * * *$ \\
\hline & (0.0137) & (0.0202) \\
\hline \multirow[t]{2}{*}{ Part-Time Employed } & -0.0250 & -0.0101 \\
\hline & $(0.0155)$ & $(0.0190)$ \\
\hline \multirow[t]{2}{*}{ Out of the Labor Force } & -0.0164 & -0.0241 \\
\hline & $(0.0148)$ & $(0.0166)$ \\
\hline \multirow[t]{2}{*}{ On Maternity Leave } & 0.0160 & 0.0014 \\
\hline & (0.0259) & $(0.0268)$ \\
\hline \multirow[t]{2}{*}{ Unemployed } & 0.0004 & -0.0270 \\
\hline & (0.0173) & (0.0196) \\
\hline \multirow[t]{2}{*}{ Household Income } & $-0.0198 * * *$ & -0.0118 \\
\hline & (0.0052) & (0.0104) \\
\hline \multirow[t]{2}{*}{ Distance to the Next Nuclear Power } & $-0.0010 * *$ & -0.0007 \\
\hline & $(0.0004)$ & $(0.0045)$ \\
\hline$R^{2}$ & 0.0138 & 0.0075 \\
\hline $\boldsymbol{N}$ & 20,178 & 20,178 \\
\hline
\end{tabular}




\begin{tabular}{|c|c|c|c|c|}
\hline & \multicolumn{4}{|c|}{ Very Concerned About the Environment } \\
\hline & $\begin{array}{c}\text { Only Pre-Scheduled } \\
\text { Interviews }\end{array}$ & $\begin{array}{l}\text { Excludes CAPI } \\
\text { Interviews }\end{array}$ & $\begin{array}{c}\text { Excludes CAPI+Postal } \\
\text { Interviews }\end{array}$ & $\begin{array}{c}\text { Includes Only CAPI } \\
\text { Interviews }\end{array}$ \\
\hline & (1) & (2) & (3) & (4) \\
\hline PostMarch11 $1_{i, 2011} * 2011$ ("After Meltdown") & $\begin{array}{c}0.0793 * * * \\
(0.0150)\end{array}$ & $\begin{array}{c}0.0597^{* * *} \\
(0.0091)\end{array}$ & $\begin{array}{l}0.0464 * * \\
(0.0232)\end{array}$ & $\begin{array}{c}0.0985 * * * \\
(0.0201)\end{array}$ \\
\hline PostMay30 $_{\mathrm{i}, 2011}$ *2011 ("After Shutdown") & $\begin{array}{c}-0.1248 * * * \\
(0.0248)\end{array}$ & $\begin{array}{c}-0.1070 * * * \\
(0.0168)\end{array}$ & $\begin{array}{c}-0.1776 * * * \\
(0.0340)\end{array}$ & $\begin{array}{c}-0.1053 * * * \\
(0.0344)\end{array}$ \\
\hline \multicolumn{5}{|l|}{ Controls } \\
\hline Demographic Characteristics & Yes & Yes & Yes & Yes \\
\hline Educational Characteristics & Yes & Yes & Yes & Yes \\
\hline Labor Market Characteristics & Yes & Yes & Yes & Yes \\
\hline Year Fixed Effects & Yes & Yes & Yes & Yes \\
\hline Month Fixed Effects & Yes & Yes & Yes & Yes \\
\hline$R^{2}$ & 0.0153 & 0.0076 & 0.0271 & 0.0199 \\
\hline$N$ & 9,311 & 15,206 & 4,487 & 4,824 \\
\hline
\end{tabular}

Note: ${ }^{*} p<0.1,{ }^{* *} p<0.05, * * * p<0.01 ;$ standard errors are in parentheses and clustered at the interview date level. Treatment status is defined by the time-invariant dummy variables PostMarch $11_{i, 2011}$ and PostMay $30_{i, 2011}$, which drop out in the individual FE models. The dependent variable is a dummy variable which equals one if the individual is very concerned about the environment. There are ten different categories of interviews, but only four are of quantitative relevance: (a) oral interviews, pre-scheduled and carried out by a professional interviewer at the respondent's home (19\%), (b) self-administered interviews, filled out by the respondent without the help of an interviewer (29\%), (c) written interviews, sent in by mail (20\%), and (d) CAPI interviews, pre-scheduled and carried out by a professional interviewer at the respondent's home at a computer (25\%). Column (1) excludes categories (b) and (c). Column (2) excludes category (d). Column (3) excludes categories (c) and (d). Column (4) excludes all categories except for (d). Each column stands for one FE model similar to Equation (1).

Source: SOEP v29, 2010-2011, balanced panel, own calculations. 


\begin{tabular}{|c|c|c|c|c|}
\hline & \multicolumn{4}{|c|}{ Very Concerned About the Environment } \\
\hline & $\begin{array}{l}\text { Uses Alternative } \\
\text { Policy Date for } \\
\text { Phase-Out }\end{array}$ & $\begin{array}{l}\text { Excludes Individ- } \\
\text { uals That Moved } \\
\text { Out of 50km Ra- } \\
\text { dius to Birth Place }\end{array}$ & $\begin{array}{l}\text { Excludes Individ- } \\
\text { uals That Moved } \\
\text { in Previous Period }\end{array}$ & $\begin{array}{l}\text { Includes Only Pre- } \\
\text { Scheduled Inter- } \\
\text { views }\end{array}$ \\
\hline & (1) & (2) & (3) & (4) \\
\hline \multirow[t]{2}{*}{ PostMarch11 ${ }_{\mathrm{i}, 2011}{ }^{*} 2011$ ("After Meltdown") } & $0.0610 * * *$ & $0.0874 * * *$ & $0.0752 * * *$ & $0.0794 * * *$ \\
\hline & $(0.0086)$ & $(0.0121)$ & $(0.0090)$ & (0.0149) \\
\hline \multirow{2}{*}{ PostMay30 ${ }_{i, 2011}{ }^{*} 2011$ (“After Shutdown") } & & $-0.1338 * * *$ & $-0.1114 * * *$ & $-0.1203 * * *$ \\
\hline & & $(0.0213)$ & $(0.0163)$ & $(0.0246)$ \\
\hline \multirow{2}{*}{ PostJune $30_{\mathrm{i}, 2011} * 2011$} & $-0.0959 * * *$ & & & \\
\hline & $(0.0213)$ & & & \\
\hline \multicolumn{5}{|l|}{ Controls } \\
\hline Demographic Characteristics & Yes & Yes & Yes & Yes \\
\hline Educational Characteristics & Yes & Yes & Yes & Yes \\
\hline Labor Market Characteristics & Yes & Yes & Yes & Yes \\
\hline Year Fixed Effects & Yes & Yes & Yes & Yes \\
\hline Month Fixed Effects & Yes & Yes & Yes & Yes \\
\hline Linear Time Trend & Yes & Yes & Yes & Yes \\
\hline$R^{2}$ & 0.0061 & 0.0130 & 0.0082 & 0.0144 \\
\hline$N$ & 20,178 & 9,837 & 19,904 & 9,424 \\
\hline \multicolumn{5}{|c|}{$\begin{array}{l}\text { Note: }{ }^{*} p<0.1, * * p<0.05, * * * p<0.01 ; \text { standard errors are in parentheses and clustered at the interview date level. Treatment status is defined by the } \\
\text { time-invariant dummy variables PostMarch } 11_{\mathrm{i}, 2011} \text { and PostMay } 30_{\mathrm{i}, 2011} \text {, which drop out in the individual FE models. The dependent variable is a dum- } \\
\text { my variable which equals one if the individual is very concerned about the environment. Column (1) uses June } 30,2011 \text {, as the relevant policy date } \\
\text { for the phase-out, as the phase-out bill was formally passed by the parliament on that date. Column (2) excludes individuals that moved out of a } \\
50 \mathrm{~km} \text { radius to their birth place. Column (3) excludes individuals that moved in the previous period. Column (4) includes only pre-scheduled inter- } \\
\text { views. Each column stands for one FE model similar to Equation (1). } \\
\text { Source: SOEP v29, 2010-2011, balanced panel, own calculations. }\end{array}$} \\
\hline
\end{tabular}


Table A7: Effects on Environmental Concerns in Germany (Robustness Checks III)

\begin{tabular}{|c|c|c|c|c|}
\hline & \multicolumn{4}{|c|}{ Very Concerned About the Environment } \\
\hline & $\begin{array}{c}\text { Adds } \\
\text { Linear Time Trend } \\
\text { After Meltdown }\end{array}$ & $\begin{array}{c}\text { Adds } \\
\text { Linear Time Trend } \\
\text { After Policy }\end{array}$ & $\begin{array}{c}\text { Adds } \\
\text { Quadratic Time } \\
\text { Polynomial }\end{array}$ & $\begin{array}{c}\text { Uses Unbalanced } \\
\text { Panel }\end{array}$ \\
\hline & (1) & $(2)$ & (3) & (4) \\
\hline \multirow[t]{2}{*}{ PostMarch11 ${ }_{\mathrm{i}, 2011}{ }^{*} 2011$ ("After Meltdown") } & $0.0717^{* * *}$ & $0.0733 * * *$ & $0.0880 * * *$ & $0.0713^{* * *}$ \\
\hline & $(0.0094)$ & $(0.0088)$ & $(0.0140)$ & $(0.0088)$ \\
\hline \multirow{2}{*}{ PostMay30 $_{\mathrm{i}, 2011}$ *2011 ("After Shutdown") } & $-0.0997 * * *$ & $-0.1144 * * *$ & $-0.0587 * * *$ & $-0.0994 * * *$ \\
\hline & (0.0159) & $(0.0154)$ & $(0.0277)$ & (0.0159) \\
\hline \multicolumn{5}{|l|}{ Controls } \\
\hline Demographic Characteristics & Yes & Yes & Yes & Yes \\
\hline Educational Characteristics & Yes & Yes & Yes & Yes \\
\hline Labor Market Characteristics & Yes & Yes & Yes & Yes \\
\hline Year Fixed Effects & Yes & Yes & Yes & Yes \\
\hline Month Fixed Effects & Yes & Yes & Yes & Yes \\
\hline Linear Time Trend & Yes & Yes & Yes & Yes \\
\hline$R^{2}$ & 0.0075 & 0.0086 & 0.0078 & 0.0075 \\
\hline $\mathbf{N}$ & 20,178 & 20,178 & 20,178 & 26,369 \\
\hline
\end{tabular}

Note: ${ }^{*} p<0.1, * * p<0.05, * * * p<0.01$; standard errors are in parentheses and clustered at the interview date level. Treatment status is defined by the time-invariant dummy variables PostMarch $11_{i, 2011}$ and PostMay30 $0_{i, 2011}$, which drop in the individual FE models. The dependent variable is a dummy variable which equals one if the individual is very concerned about the environment. Column (1) adds a linear time trend which starts after the meltdown. Column (2) adds a linear time trend which starts after the policy action. Column (3) adds a quadratic time polynomial to the linear time trend. Column (4) uses an unbalanced and is equivalent to Column (4) of Table 1. Columns (1) and (2) stand for FE models similar to Equation (2). Columns (3) and (4) stand for FE models similar to Equation (1).

Source: SOEP v29, 2010-2011, own calculations. 


\begin{tabular}{|c|c|c|c|c|c|c|}
\hline & \multirow{2}{*}{\multicolumn{2}{|c|}{$\begin{array}{c}\text { Placebo Years } \\
\text { Very Concerned About } \\
\text { the Environment }\end{array}$}} & \multicolumn{4}{|c|}{ Placebo Dependent Variables: Very Concerned About } \\
\hline & & & \multirow{2}{*}{$\begin{array}{c}\text { Job Security } \\
2011 \\
\end{array}$} & \multirow{2}{*}{$\begin{array}{c}\text { Health } \\
2011 \\
\end{array}$} & \multirow{2}{*}{$\begin{array}{c}\text { the Economy } \\
2011\end{array}$} & \multirow{2}{*}{$\begin{array}{l}\text { Crime } \\
2011\end{array}$} \\
\hline & 2010 & 2012 & & & & \\
\hline & (1) & (2) & (3) & (4) & (5) & (6) \\
\hline PostMarch11 $1_{\mathrm{i}, 2010} * 2010$ & $\begin{array}{c}0.0105 \\
(0.0077)\end{array}$ & & & & & \\
\hline PostMarch11 $1_{\mathrm{i}, 2012} * 2012$ & & $\begin{array}{l}-0.0035 \\
(0.0262)\end{array}$ & & & & \\
\hline PostMay30 $_{\mathrm{i}, 2012} * 2012$ & & $\begin{array}{c}0.0649 \\
(0.0500)\end{array}$ & & & & \\
\hline PostMarch11 ${ }_{\mathrm{i}, 2011}{ }^{*} 2011$ ("After Meltdown") & & & $\begin{array}{l}-0.0088 \\
(0.0124)\end{array}$ & $\begin{array}{c}0.0078 \\
(0.0080)\end{array}$ & $\begin{array}{c}0.0087 \\
(0.0127)\end{array}$ & $\begin{array}{l}-0.0075 \\
(0.0116)\end{array}$ \\
\hline PostMay30 $_{\mathrm{i}, 2011}{ }^{*} 2011$ (“After Shutdown”) & & & $\begin{array}{c}0.0277 \\
(0.0189)\end{array}$ & $\begin{array}{l}-0.0114 \\
(0.0152)\end{array}$ & $\begin{array}{c}0.0386 \\
(0.0263)\end{array}$ & $\begin{array}{c}0.0328 \\
(0.0255)\end{array}$ \\
\hline \multicolumn{7}{|l|}{ Controls } \\
\hline Socio-Economic Characteristics & Yes & Yes & Yes & Yes & Yes & Yes \\
\hline Year, Month, and Individual Fixed Effects & Yes & Yes & Yes & Yes & Yes & Yes \\
\hline Linear Time Trend & Yes & Yes & Yes & Yes & Yes & Yes \\
\hline$R^{2}$ & 0.0041 & 0.0126 & 0.0281 & 0.0043 & 0.0979 & 0.0125 \\
\hline$N$ & 21,944 & 17,754 & 11,526 & 20,178 & 20,178 & 20,178 \\
\hline \multicolumn{7}{|c|}{$\begin{array}{l}\text { Note: } * \mathrm{p}<0.1, * * \mathrm{p}<0.05, * * * \mathrm{p}<0.01 \text {; standard errors are in parentheses and clustered at the interview date level. Treatment status is defined by the time-invariant dummy variable } \\
\text { PostMarch11 } 1_{\mathrm{i}, 2011} \text { and PostMay } 30_{\mathrm{i}, 2011} \text {, which drop out in the individual FE models. The dependent variable is a dummy variable which equals one if the individual is very concernec } \\
\text { about the environment. Columns (1) and (2) use the placebo years } 2010 \text { and } 2012 \text {. Columns (3) to (6) use placebo dependent variables, which are dummy variables that equal one } \mathrm{i} \\
\text { the individual is very concerned about job security, health, the economy, and crime. Each column stands for one FE model similar to Equation (1). } \\
\text { Source: SOEP v29, 2009-2012, balanced panel, own calculations. }\end{array}$} \\
\hline
\end{tabular}




\begin{tabular}{|c|c|c|c|c|c|c|}
\hline & \multicolumn{6}{|c|}{ Very Concerned About the Environment } \\
\hline & \multicolumn{2}{|c|}{ Real Policy Dates } & \multicolumn{4}{|c|}{ Placebo Policy Dates } \\
\hline & (1) & (2) & (3) & (4) & (5) & (6) \\
\hline PostMarch11 $1_{\mathrm{i}, 2011} * 2011$ & $0.0713^{* * *}$ & $0.0610 * * *$ & & & $0.0728^{* * *}$ & $0.0726 * * *$ \\
\hline ("After Meltdown") & $(0.0088)$ & $(0.0086)$ & $(0.0147)$ & (0.0147) & $(0.0147)$ & $(0.0147)$ \\
\hline PostMay30 $_{\mathrm{i}, 2011} * 2011$ & $-0.0994 * * *$ & & & & & \\
\hline ("After Permanent Shutdown") & (0.0159) & & & & & \\
\hline \multirow[t]{2}{*}{ PostJune $30_{\mathrm{i}, 2011} * 2011$} & & $-0.0959 * * *$ & & & & \\
\hline & & (0.0213) & & & & \\
\hline \multirow[t]{2}{*}{ PostMay15 $_{\mathrm{i}, 2011} * 2011$} & & & -0.0158 & & & \\
\hline & & & $(0.0246)$ & & & \\
\hline \multirow{2}{*}{ PostMay17 ${ }_{\mathrm{i}, 2011} * 2011$} & & & & -0.0010 & & \\
\hline & & & & $(0.0238)$ & & \\
\hline \multirow[t]{2}{*}{ PostJune $15_{\mathrm{i}, 2011} * 2011$} & & & & & -0.0089 & \\
\hline & & & & & $(0.0298)$ & \\
\hline \multirow[t]{2}{*}{ PostJuly15 ${ }_{\mathrm{i}, 2011} * 2011$} & & & & & & 0.0443 \\
\hline & & & & & & $(0.0380)$ \\
\hline \multicolumn{7}{|l|}{ Controls } \\
\hline Socio-Economic Characteristics & Yes & Yes & Yes & Yes & Yes & Yes \\
\hline Year, Month, and Individual FE & Yes & Yes & Yes & Yes & Yes & Yes \\
\hline Linear Time Trend & Yes & Yes & Yes & Yes & Yes & Yes \\
\hline$R^{2}$ & 0.0075 & 0.0061 & 0.0083 & 0.0083 & 0.0083 & 0.0083 \\
\hline$N$ & 20,178 & 20,178 & 20,178 & 20,178 & 20,178 & 20,178 \\
\hline \multicolumn{7}{|c|}{ 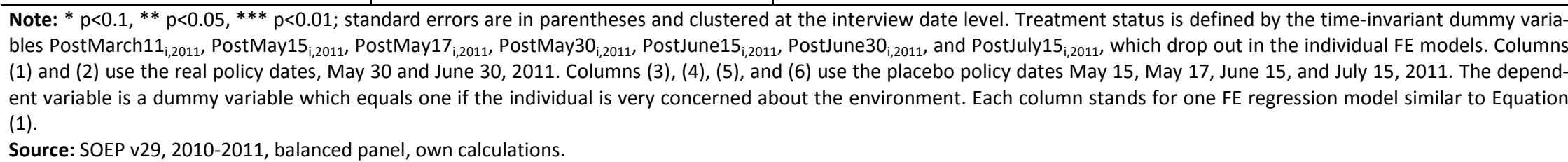 } \\
\hline
\end{tabular}




\begin{tabular}{|c|c|c|c|c|}
\hline & \multicolumn{4}{|c|}{ Very Risk Averse } \\
\hline & OLS & OLS & FE & FE \\
\hline & (1) & (2) & (3) & (4) \\
\hline PostMarch11 $1_{i, 2011} * 2011$ (“After Meltdown") & $(0.0092)$ & $(0.0084)$ & $(0.0060)$ & $(0.0060)$ \\
\hline PostMay30 $_{\mathrm{i}, 2011}{ }^{*} 2011$ (“After Shutdown”) & -0.0087 & -0.0070 & 0.0016 & 0.0021 \\
\hline \multirow[t]{2}{*}{ PostMarch11 $1_{i, 2011}$} & -0.0038 & 0.0032 & & \\
\hline & $(0.0071)$ & $(0.0066)$ & & \\
\hline \multirow[t]{2}{*}{ PostMay30 ${ }_{i, 2011}$} & 0.0066 & 0.0045 & & \\
\hline & (0.0089) & (0.0087) & & \\
\hline 2011 & $-0.0014 * *$ & $-0.0015 * * *$ & $-0.0026 * * *$ & $-0.0026 * * *$ \\
\hline Educational Characteristics & No & Yes & No & Yes \\
\hline Labor Market Characteristics & No & Yes & No & Yes \\
\hline Year Fixed Effects & Yes & Yes & Yes & Yes \\
\hline Month Fixed Effects & Yes & Yes & Yes & Yes \\
\hline Linear Time Trend & Yes & Yes & Yes & Yes \\
\hline$R^{2}$ & 0.0033 & 0.0535 & 0.0072 & 0.0085 \\
\hline $\mathbf{N}$ & 20,178 & 20,178 & 20,178 & 20,178 \\
\hline
\end{tabular}

Note: ${ }^{*} p<0.1, * * p<0.05, * * * p<0.01$; standard errors are in parentheses and clustered at the interview date level. Treatment status is defined by the time-invariant dummy variables PostMarch11 $1_{i, 2011}$ and PostMay $30_{i, 201}$, which drop out in the individual FE models. The dependent variable is a dummy variable which equals one if the individual is very risk averse (0-1/10 on the risk attitude scale). Each column stands for one regression model similar to Equation (1).

Source: SOEP v29, 2009-2012, balanced panel, own calculations. 
Table A11: Effects on Environmental Concerns in Germany in a Pure RD Design

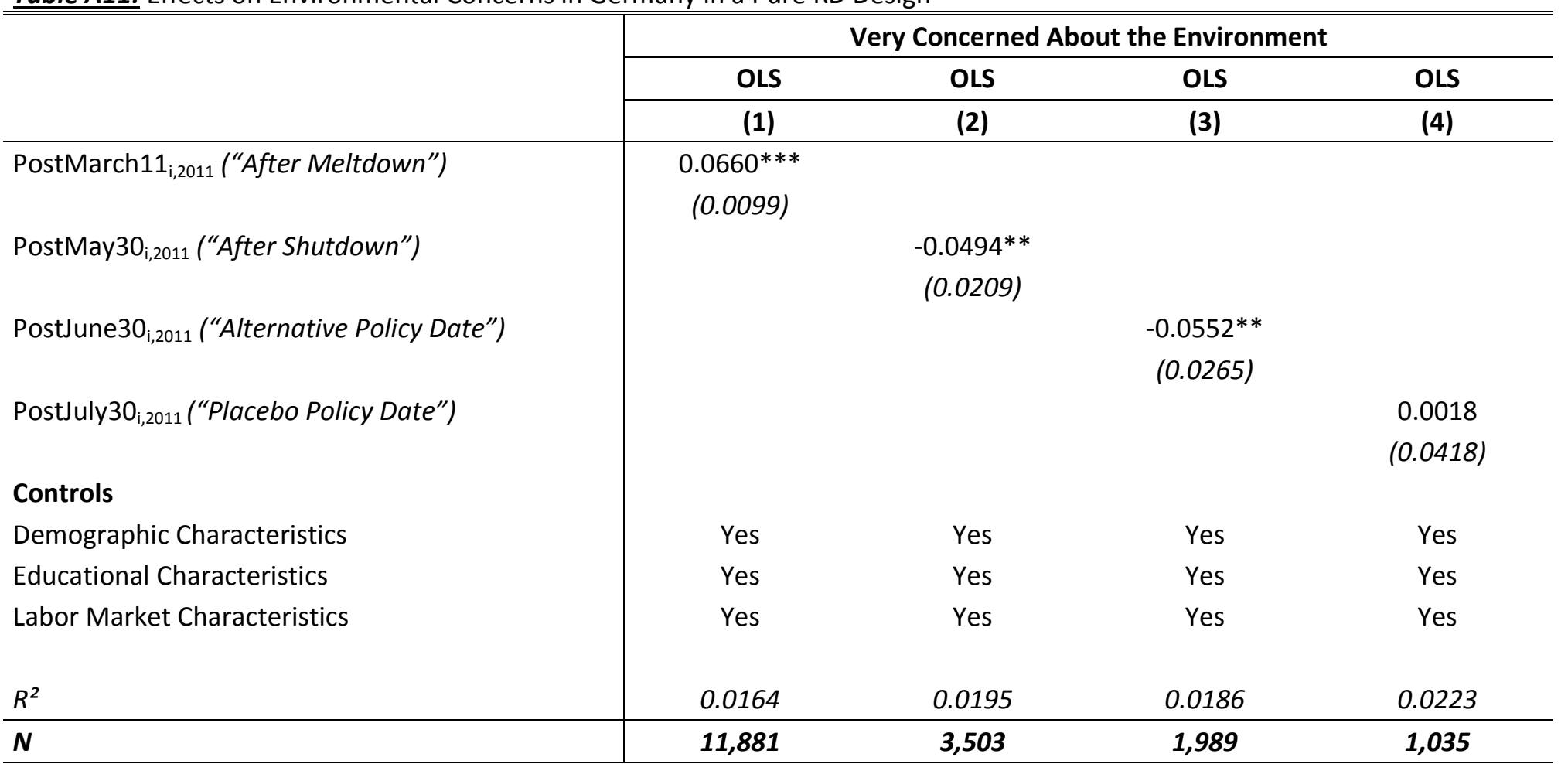

Note: ${ }^{*} p<0.1, * * p<0.05, * * * p<0.01$; standard errors are in parentheses and clustered at the interview date level. Treatment status is defined by the time-invariant treatment dummy variables PostMarch11 $1_{i, 2011}$, PostMay30 $0_{i, 2011}$, PostJune $30_{i, 2011}$, and PostJuly30 $0_{i, 2011}$. The dependent variable is a dummy variable which equals one if the individual is very concerned about the environment. Each column stands for one local linear regression model around the respective cut-off date, plus minus 45 days, i.e. the identification of the effects is based on a pure regression discontinuity design. Note that this approach relies only on cross sectional data for 2011.

Source: SOEP v29, 2011, own calculations. 
Table A12: Effects on Life Satisfaction in Germany (Richter et al. (2013) - Replication I)

\begin{tabular}{|c|c|c|c|c|c|}
\hline \multirow[b]{2}{*}{ Life Satisfaction } & \multirow{2}{*}{\begin{tabular}{|c|} 
Original Model \\
OLS
\end{tabular}} & \multicolumn{4}{|c|}{ Augmented Models } \\
\hline & & $\begin{array}{c}\text { OLS } \\
\text { (+ Clustering) }\end{array}$ & $\begin{array}{c}\text { OLS } \\
\text { (+ Linear Time Trend) }\end{array}$ & $\begin{array}{c}\text { OLS } \\
\text { (+ Month Fixed Effects) }\end{array}$ & $\begin{array}{c}\text { OLS } \\
\text { (+ Individual Fixed Effects) }\end{array}$ \\
\hline $\begin{array}{l}\text { Before Fukushima accident: } \\
02 / 01 / 2011-03 / 10 / 2011\end{array}$ & (Ref.) & (Ref.) & (Ref.) & (Ref.) & (Ref.) \\
\hline Fukushima accident: & 0.055 & 0.055 & -0.008 & 0.016 & 0.134 \\
\hline $03 / 11 / 2011-06 / 05 / 2011$ & (0.036) & (0.046) & $(0.047)$ & (0.063) & $(0.842)$ \\
\hline Nuclear phase-out: & $0.131^{* * *}$ & $0.131^{* *}$ & -0.059 & -0.129 & 0.100 \\
\hline $06 / 06 / 2011-09 / 30 / 2011$ & $(0.046)$ & $(0.057)$ & (0.102) & $(0.166)$ & (0.843) \\
\hline Observations & 17,571 & 17,571 & 17,571 & 17,571 & 35,964 \\
\hline$R^{2}$ & 0.333 & 0.333 & 0.334 & 0.334 & 0.077 \\
\hline $\begin{array}{l}\text { Notes: }{ }^{*} p<0.1,{ }^{* *} p<0.05,{ }^{* * *} \\
\text { dependent variable is general } \\
\text { (squared), log household incor } \\
\text { development, state dummies a }\end{array}$ & $\begin{array}{l}0.01 \text {; standard e } \\
\text { e satisfaction (cod } \\
\text { e, child in househ } \\
\text { d regional dummy }\end{array}$ & $\begin{array}{l}\text { are in paren } \\
-10) ; \text { cross } \\
\text { marital status } \\
\text { t). }\end{array}$ & $\begin{array}{l}\text { s and clustered at the } i \\
\text { nal weights for all wav } \\
\text { loyment status, educa }\end{array}$ & $\begin{array}{l}\text { al level. OLS and ordere } \\
\text { pplied. Considered cove } \\
\text { orries about own econo }\end{array}$ & $\begin{array}{l}\text { estimates are estimated. The } \\
\text { are: Health, gender, age, age } \\
\text { uation and overall economic }\end{array}$ \\
\hline
\end{tabular}


Table A13: Effects on Life Satisfaction in Germany (Richter et al. (2013) - Replication II)

\begin{tabular}{|c|c|c|c|c|c|}
\hline & Original Model & \multicolumn{4}{|c|}{ Augmented Models } \\
\hline $\begin{array}{l}\text { Very Concerned } \\
\text { About Environment }\end{array}$ & OLS & $\begin{array}{c}\text { OLS } \\
\text { (+ Clustering) }\end{array}$ & $\begin{array}{c}\text { OLS } \\
\text { (+ Linear Time Trend) }\end{array}$ & $\begin{array}{c}\text { OLS } \\
\text { (+ Month Fixed Effects) }\end{array}$ & $\begin{array}{c}\text { OLS } \\
\text { (+ Individual Fixed Effects) }\end{array}$ \\
\hline $\begin{array}{l}\text { Before Fukushima accident: } \\
02 / 01 / 2011-03 / 10 / 2011\end{array}$ & (Ref.) & (Ref.) & (Ref.) & (Ref.) & (Ref.) \\
\hline $\begin{array}{l}\text { Fukushima accident: } \\
\text { 03/11/2011-06/05/2011 }\end{array}$ & $\begin{array}{c}0.060 * * * \\
(0.010)\end{array}$ & $\begin{array}{c}0.060 * * * \\
(0.011)\end{array}$ & $\begin{array}{c}0.051 * * * \\
(0.013)\end{array}$ & $\begin{array}{r}0.048 * * \\
(0.019)\end{array}$ & $\begin{array}{c}0.046^{* * *} \\
(0.017)\end{array}$ \\
\hline $\begin{array}{l}\text { Nuclear phase-out: } \\
\text { 06/06/2011-09/30/2011 }\end{array}$ & $\begin{array}{l}-0.017 \\
(0.011)\end{array}$ & $\begin{array}{l}-0.017 \\
(0.012)\end{array}$ & $\begin{array}{l}-0.044 * \\
(0.026)\end{array}$ & $\begin{array}{l}-0.048 \\
(0.050)\end{array}$ & $\begin{array}{c}-0.041^{* *} \\
(0.021)\end{array}$ \\
\hline $\begin{array}{l}\text { Observations } \\
R^{2}\end{array}$ & $\begin{array}{c}20,021 \\
0.081\end{array}$ & $\begin{array}{c}20,021 \\
0.081\end{array}$ & $\begin{array}{c}20,021 \\
0.082\end{array}$ & $\begin{array}{c}20,021 \\
0.082\end{array}$ & $\begin{array}{c}38,429 \\
0.018\end{array}$ \\
\hline $\begin{array}{l}\text { Notes: } * p<0.1, * * p<0.05, * * * \\
\text { The dependent variable is a du } \\
\text { are applied. Considered covaria } \\
\text { cation, worries about own econ }\end{array}$ & $\begin{array}{l}\text { 1; standard erro } \\
\text { variable which e } \\
\text { e: Health, gend } \\
\text { situation and ov }\end{array}$ & $\begin{array}{l}\text { re in parenthe } \\
\text { Is one if the in } \\
\text { ge, age (squar } \\
\text { l economic del }\end{array}$ & $\begin{array}{l}\text { and clustered at the ind } \\
\text { dual is very concerned a } \\
\text { log household income, } \\
\text { pment, state dummies a }\end{array}$ & $\begin{array}{l}\text { dual level. OLS and ordere } \\
\text { ut the environment. Cros } \\
\text { ild in household, marital s } \\
\text { regional dummy (East). }\end{array}$ & $\begin{array}{l}\text { ogit estimates are estimated. } \\
\text { ectional weights for all waves } \\
\text { tus, employment status, edu- }\end{array}$ \\
\hline
\end{tabular}

